\title{
Commercial Success and Patent Standards: Economic Perspectives on Innovation
}

\author{
Robert P. Merges
}

TABLE OF CONTENTS

Page

I. Introduction $\ldots \ldots \ldots \ldots \ldots \ldots \ldots \ldots \ldots \ldots \ldots \ldots \ldots \ldots$

A. Invention, Innovation, and the Patent System ....... 806

B. Basic Requirements for a Patent ............... 811

II. Commercial Success and Other Secondary Considerations .. 816

A. Origins of the Secondary Considerations .......... 816

B. The Federal Circuit and Secondary Considerations..... 819

1. Origins of the Federal Circuit ............... 821

2. Substantive Aspects of the Secondary Considerations ........................... 823

a. Commercial Success ..................... 823

b. Other Secondary Factors ............... 828

3. Secondary Factors: Evidentiary and Procedural

Aspects .............................. 832

a. Burden of Proof ..................... 832

b. Weight versus Relevance ................ 833

c. Standard of Review...................... 835

III. Analytical and Economic Approaches to the Secondary Considerations ............................. 837

A. Commercial Success and the Long Inferential Trail .... 838

B. An Econonic Critique of Commercial Success........ 842

1. Schumpeter and the Economic Study of Innovation

2. Models of Innovation as a Race ............. 846

a. An Overview ........................ 846

b. The Kamien and Schwartz Model........... 847

3. A Dynamic Model of Innovation ............. 850

C. Empirical Evidence on Innovation $\ldots \ldots \ldots \ldots \ldots \ldots \ldots .852$

1. Studies of Innovation .................... 852

2. Selected Cases: Further Empirical Support........ 855

IV. The Consequences of Current Secondary Factors Doctrine.. 859 
A. The Costs of Commercial Success.............. 860

B. The Other Secondary Considerations ............ 862

1. Failure of Others: The Legacy of Learned Hand ... 862

2. Licensing By Competitors .................. 866

3. Long-Felt Need......................... 872

4. Copying $. . \ldots \ldots \ldots \ldots \ldots \ldots \ldots \ldots \ldots \ldots \ldots \ldots \ldots \ldots \ldots \ldots, 872$

V. What Should Be Done About the Secondary

Considerations .................................. 874

A. Commercial Success ........................... 874

B. Other Secondary Factors $\ldots \ldots \ldots \ldots \ldots \ldots \ldots \ldots \ldots .875$

Conclusion ....................................... 876 


\title{
Commercial Success and Patent Standards: Economic Perspectives on Innovation
}

\author{
Robert P. Merges†
}

This Article criticizes a recent line of patent decisions in which the Court of Appeals for the Federal Circuit has considered evidence of an innovation's commercial success in deciding whether to award a patent to the innovator. Professor Merges briefly reviews the history of patent law and concludes that one of its principle purposes is to reward "invention," or the achievement of a signiflcant technical advance and thereby to spur innovative technological development. He notes, however, that recently, the Federal Circuit has begun to consider "secondary factors," including the financial success of a commercialized invention, and the extent to which other firms have licensed it, in determining whether the invention constitutes a significant technical advance worthy of patent protection. Moreover, he asserts that the Federal Circuit has increased dramatically the importance of these factors by not only giving them substantive weight, but also by reducing evidentiary and procedural obstacles to their use.

The Author employs empirical economic research and economic theory to illustrate that this trend is counterproductive. Reliance on secondary factors, he argues, tends to reward nontechnical achievements such as superior distribution systems, marketing decisions, and service networks, instead of rewarding actual invention. As a result, he concludes, the Federal Circuit's decisions may be impairing the patent system by rewarding inventions that are commercially successful but that represent relatively minor technological advances. The Article concludes with some alternative approaches that more appropriately proscribe the use of commercial success and licensing as factors in determining patentability.

\section{INTRODUCTION}

New economic challenges now face the United States. Both government and private imdustry have expressed growing concern over increased competition from abroad and declining growth and productiv-

$\dagger$ Associate Professor, Boston University School of Law; B.S., Carnegie Mellon University, 1981; J.D., Yale Law School, 1985. I would like to thank Professor Harold Edgar, Director of the Julius Silver Program in Law, Science and Technology at Columbia Law School, for his helpful comments and general support during the writing of this Article, and Professor Richard Nelson of Columbia for his patience in reviewing an earlier draft and in introducing me to the economic literature on innovation. I also wish to acknowledge the financial support of the Silver Program. 
ity at home. This concern has produced a heightened awareness of the importance of technological research and development, and along with this, a commitment to enhancing the incentives for firms to develop innovative technologies. Since patents are considered one of the most important incentives to innovate, ${ }^{1}$ it is no surprise that policymakers have becoine mcreasingly imterested in strengthening the patent system.

The most important step toward reform of the patent system came in 1982, with the creation of a unified court for patent appeals, the Court of Appeals for the Federal Circuit. The Federal Circuit has increased the stability and predictability of patent doctrine, to the benefit of innovative private firms. Notwithstanding these benefits, one trend in Federal Circuit decisions actually threatens to undermine the patent system's key economic goal of encouraging technological advance. A recent line of Federal Circuit decisions has emphasized such factors as the financial success of a commercialized imvention, or the extent to which other firms have hicensed it, in deciding whether it is patentable. By relying on this "objective evidence" of patentability, as the Federal Circuit calls it, the court threatens to transform patents into rewards for such nontechnical achieveınents as superior distribution systems, marketimg decisions, and service networks. In so doing, it has begun to undermine the patent systein's traditional emphasis on rewarding invention. Thus the Federal Circuit, created by Congress to strengthen and stabilize the patent system, may actually be weakening it by rewarding inventions that are commercially successful but that represent relatively minor technological advances.

My goals in this Article are twofold: First to show that the Federal Circuit's emphasis on commercial success is fundamentally unsound and second to generate interest in economic research dealing with innovation. In the remainder of this section, I sketch out soine basic assumptions and requirements of the patent systein. Section II focuses on the development of commercial success as a inajor "objective" factor in patentability. In Section III, I analyze theoretical and empirical work by economists who have studied technological invention and innovation. Drawing on this analysis, I argue in Section IV that the current overemphasis on commercial success is counterproductive. The final section proposes some alternative approaches that more appropriately proscribe the use of commercial success and licensing as factors in determining patentability.

\section{A. Invention, Innovation, and the Patent System}

Although there are a number of ways to describe the stream of

1. See infra notes $158-67$ and accompanying text. 
events which begin with an idea for a new product or process and end with its first commercial sale, economists who study these events have settled on a few standard terms to describe them. ${ }^{2}$ As part of my analysis, I will need to distinguish between two of these terms-invention and innovation. The distinction between invention and innovation is crucial to an understanding of the development path of new technology. Moreover, this distinction is crucial to an understanding of the functions of the patent system, and how the system's structure carries out those functions.

An invention refers to the practical implementation of the imventor's idea. This often takes the form of a prototype or model. An invention, then, is more than a concept (it is usually a tangible thimg), but less than the fully worked out product or process first offered for sale to customers. ${ }^{3}$ An innovation is the "debugged" and functional version of the invention: the version first offered for sale.

In many cases, an invention will become part of an existing product or process, in which case the innovation is just a new version of the product or process. In other instances, the invention will constitute an entire free-standing product, and will be sold essentially by itself. In both cases, however, the innovation will in all likelihood be different in significant respects from the invention due to the changes necessary to turn the invention into a commercial product. ${ }^{4}$

2. See, e.g., Study of the Subcommitee on Patents, Trademarks and Copyrights of the Senate Judiciary Committee, 85Th CoNG., 2D SESS., AN Economic Review of the Patent System, Study No. 15, 1-7 (Comm. Print 1958) (written by the noted economist Fritz Machlup) [hereinafter Machiup, Economic Review]; C. Freeman, The Economics of INDUSTRIAL INNOVATION 53-68 (2d ed. 1980); R. NELSON \& S. WINTER, AN EVOLUTIONARY THEORY OF ECONOMIC CHANGE (1982); F.M. SCHERER, INNOVATION AND GROWTH: SCHumpeterian Perspectives 1-31 (1984).

3. A patent application need not be backed up by a working model or prototype. The filing of the application constitutes a constructive "reduction to practice" of the idea. R. CHOATE, W. Francis \& R. Colins, Cases and Materials on Patent Law 111-12 (3d ed. 1987). The application, lowever, must disclose more tlian a mere idea; it must also indicate a "specific tangible means or way of carrying out the new idea." Id. at 111; cf. 35 U.S.C. $\$ 102(\mathrm{~g})$ (1982) (rule of priority between two inventors who arrive at the same idea).

4. In some economic writing, an innovation is said to be any new productive factor or activity. See, e.g., R. NELSON \& S. WINTER, supra note 2, at 263-66; J. Scliumpeter, The Theory of Economic Development 66 (1934) (innovation, or "carrying out new combinations," can take five forms: "(1) The introduction of a new good. . . . (2) The introduction of a new method of production. ... (3) The opening of a new market..., (4) The conquest of a new source of supply .... (5) The carrying out of the new organi[z]ation of any industry. . . ."); O. WILLIAMSON, MARKETS AND HiERARCHIES: ANALYSIS AND ANTITRUST IMPLICATIONS 192 (1975) (stressing that relatively little attention is given to organizational innovation in most economic theory). From this perspective, what I discuss in this article would be termed technological innovations: new and tangible productive factors.

It is miportant to note that the distinction between invention and innovation has been criticized as a smiplified dualism by some economists, who argue that the process of developinent is actually much more of a continuum. See R. NELSON \& S. WINTER, supra note 2, at 263. The structure of 
We can clarify the function of the patent system by using the terminology introduced above. The patent system has one Constitutionally mandated goal: "to promote the Progress of science and useful Arts. ..."5 While there are various ways this goal might have been carried out, Congress settled upon a simple arrangement. Inventors disclose what they have discovered or invented, and society rewards them with a patent. ${ }^{6}$ The dual functions of disclosure and reward are the essence of our patent system.

A successful patent application, then, has to disclose something new. ${ }^{7}$ Througli the patent system, society obtains the benefit of both an innovation (assummg the invention is perfected and introduced for sale) and, at the very least, an invention-that is, a significant teclinical advance. Patents are published when they are granted so others may practice the invention once the patent lias expired ${ }^{8}$ and, more importantly, so others have the benefit of the inventor's discovery. ${ }^{9}$ Altliough

the patent statute, which is constructed around the notion of identifying and cordoning off a diserete invention, necessitates such a distinction. See, eg., 35 U.S.C. $\$ \S 101,102,103,112$ (1982 \& Supp. III 1985). Even advocates of the continuum view, such as Nelson and Winter, find it neessary to divide the innovation process into rough stages (at least conceptually), making their work accessible to a student of the patent system, despite that systein's perhaps Procrustean insistence on the identifiability of individual inventions. See infra note 199 and accompanying text.

5. U.S. CoNST. art. I, $\S 8$, cl. 8.

6. See, e.g., MAChluP, Economic REviEw, supra note 2, at 24-25 (discussing the " 'exchange for secrets' thesis" of the patent system); Stedman, Invention and Public Policy, 12 LAW \& CONTEMP. PROBS. 666, 666-67 (1947). Older cases in fact often referred to a patent as a "contract" between an inventor and society at large; the "consideration" given by the inventor was said to be the information on how to make his invention. See, e.g., Century Elec. Co. v. Westinghouse, 191 F. 350, 354 (8th Cir. 1911); Seymour v. Osborne, 78 U.S. (11 Wall.) 516, 533 (1870) (referring to patent as a governmentally-granted "franchise").

7. The requirement that the successful application describe something new is in 35 U.S.C. $\S 102$ (1982) (novelty); the requirement that the new subject matter be adequately described is in $i d$. \$ 112: "The specification [in the application] shall contain a written deseription of the invention ... in such full, clear, concise and exact terms as to enable any person skilled in the art . . . to make and use the same, and sliall set forth the best inode contemplated by the inventor of carrying out his invention."

8. See Grant v. Raymond, 31 U.S. (6 Pet.) 218 (1832).

9. Mansfield, How Rapidly Does New Industrial Technology Leak Out?, 34 J. INDUs. ECON. 217, 221 (1985) (identifying patent applications as one channel through which new technologies leak out to competitors); Stedınan, supra note 6, at 666; see also 35 U.S.C. $\S 102(b)$ (1982) (providing for one year grace period after publication of article describing invention during which application may be filed, thus encouraging early publication of results); id. $\S 102(\mathrm{~g})$ (1982) (in determining priority of invention, inventor who conceives of invention first but does not diligently reduce it to practice before another inventor does will lose out, since public interest in disclosurc is important). For a discussion of $\S 102(\mathrm{~g})$, see Autoinatic Weighing Machine Co. v. Pneunatic Scale Corp., 166 F. 288 (1st Cir. 1909) (prior conception does not lead to priority where there is a lack of diligence in reducing an invention to practice).

There is a significant amount of evidence showing that inventors in many fields rely on published patents for technical information. This evidence takes several forms. First, trade magazines describe at the practical level of the R\&D inanager the benefits of patent data for keeping up with coinpetitors. See, e.g., Allcock \& Lotz, Gleaning Corporate "Secrets" from Patents, 8 Снемтесн 532 (1978); Allcock \& Lotz, Patent Intelligence and Technology-Gleaning 
some have questioned the efficacy of this disclosure function, ${ }^{10}$ the patent statute and case law-not to mention commercial practices-repeatedly demonstrate its vitality in the patent system. ${ }^{11}$

Although a patent need only disclose information about an invention, there is still a good deal of development work necessary to turn the invention into an innovation. Thus, the patent system rewards innovation only imdirectly, througli the granting of patents on inventions. ${ }^{12}$ Some theorists have argued that this is a fundamental flaw in the patent system. ${ }^{13}$ They contend that the original function of patents was to reward innovation directly. ${ }^{14}$ In their view, the patent system has strayed so far from this original function that it is no longer effective. Accordimgly, they propose a new patent regime that would provide direct protection of innovation by awarding innovators exclusive rights to mar-

Pseudoproprietary Information from Publicly Available Data, 18 J. CHEM. INFo. \& COMPUTER SCI. 65 (1978). Second, some scholars studying the interdependence between technological fields present data showing citations to patents in scientific articles-an indication that patents contain technically useful information. See, e.g., Basberg, Patents and the Measurement of Technological Change: A Survey of the Literature, 16 RES. POL'Y 131 (1987) (reviewing the whole field of "patent bibliometrics"); see also Carpenter, Narin \& Woolf, Citation Rates to Technologically Important Patents, 3 World PAT. INFo. 160 (1981). Third, detailed case studies of particular industries demonstrate that patents played an important disclosure role in the developinent of many technologies. See, e.g., Koenig, A Bibliometric Analysis of Pharmaceutical Research, 12 RES. POL'Y 15 (1983). Finally, some commentators have even suggested that the line between science and technology is becoming increasingly blurred as evidenced by the cross-citation between patents and scientific articles. Narin \& Noma, Is Technology Becoming Science?, 7 Sc1ENTOMETRICs 369 (1985).

10. See Kahn, The Role of Patents, in Competition, Cartels AND THEIR Regulation 308, 317 (1962); $c f$. MACHLUP, Economic Review, supra note 2, at 76-77 (questioning whether the patent system is, on balance, the most efficient way to serve this disclosure function).

11. See supra note 9.

12. Direct Protection of InNovation 2-3 (W. Kingston, ed. 1987). However, as discussed later in this Article, sonve Federal Circuit decisions concerning patentability suggest protection of innovation as opposed to mvention. See infra notes 57-129 and acconipanying text.

13. Direct Protection of InNovation, supra note 12 , at $2-3$.

14. See Direct Protection of InNovation, supra note 12, at 1-2. This theory appears to contradict some recent historical scholarship. See, e.g., H. DutTon, The PATENT SysTeM AND INVENTIVE ACTIVITY DURING THE INDUSTRIAL REVOLUTION 1750-1852 (1984). In this thorough review of the role of the patent system during the "first" Industrial Revolution in Great Britain, Dutton concludes that the system was instrumental in fostering the development of alniost all of the key technologies of the era. In addition, in chapters on "Trade in Invention" and "Investnuent in Patents," he documents the historical connections betwecn patents and the financing of invention, illustrating along the way that, contrary to the assuniption of Direct PROTECTION OF INNOVATION, the early patent systen did not reward innovation directly, but instead played much the same role it does today. Id. at 122-74. In addition, Dutton argues that the patent systen's inefficiencies actually made it close to an idcal system, since it encouraged invention but did not prevent access to new technology by those who would try to iniprove it. Id. at 204-05; see also MacLeod, Accident or Design? Geonge Ravenscroft's Patent and the Invention of Lead-Crystal Glass, 28 TECH. \& CUlTURe 776, 776-80 (1987) (describing long time lag between invention of patented lead crystal glass and introduction of final product with "bugs" all worked out); Scherer, Invention and Innovation in the Watt-Boulton Steam-Engine Venture, 6 TECH. \& CULTURE 165, 187 (1965) (documenting the improvenients to Watt's patented steam engine technology). 
ket newly introduced products. ${ }^{15}$ They would thus shift the focus of patents to what $I$ have identified as the reward function. Disclosure would still be served in the sense that competitors would have access to the innovator's product, and could presumably learn something from it. But the current systen's goals regarding disclosure-early and fully enabling descriptions of the imnovation-would be substantially forgotten.

The notion that patents should directly reward innovation is useful for our purposes primarily because it forces us to examine the current systein's emphasis on invention, rather than innovation. It requires us to consider whether the extra disclosure occasioned by an invention-oriented patent system is worth the price paid in terms of diminished reward. ${ }^{16}$ I contend that if the disclosure is significant enough-if it informs other imventors of truly useful techniques or applications-it will offset the fact that the rewards to the inventor are lower than they inight be under another systein.

I propose that the test of the current system should be: Does the system require a level of invention that ensures that all patents will disclose a significant technical advance? I conclude that it does, if the lawmost notably the requirement of nonobviousness-is apphied correctly. ${ }^{17}$ When properly apphied, the law weeds out obvious extensions of what was already known in a technical discipline. Only inventions whose disclosure reveals a significant technical advance warrant a patent. In this way, the requirement of nonobviousness carries out the patent system's dual functions of disclosure and reward. As we shall see, however, the Federal Circuit has lessened the traditional emphasis on technical advance. By looking to such factors as commercial success and licensing in determining whether an invention is patentable, the court risks over-

15. Proponents of this view recommend that governments adopt a system of property rights which would come into effect ouly when a new product is actually introduced on the market. DiRect Protection of INNOVATION, supra note 12, at 1-34. These proposals contain some useful suggestions, as indicated by the commentators assembled to critique them. See G. TULLOCK, Intellectual Property, in id. at 171; B. WRIGHT, On the Design of a System to Improve the Production of Innovations, in id. at 227.

16. Scholars have always recognized that the reward function is one of the chief policies of the patent system. See, e.g., MACHLUP, ECONOMIC REVIEw, supra note 2, at 21 (the "reward-bymonopoly" and "monopoly-profit-incentive" theses are two of the four best-known arguments for patents, along with the "exchange for secrets" thesis, supra note 6 , and the "natural-law" thesis, holding that inventors have inherent property rights over their discoveries which the state merely accedes to in granting patents); see also F.M. Scherer, INDUSTR1AL MARKET STructure AND Economic Performance 440 (2d ed. 1980) ("Governments have chosen to grant exclusive patent rights on inventions for three main reasons: to promote invention, to encourage the development and commercial utilization of inventions, and to encourage inventors to disclose their inventions to the public.") Note that my statement in the text assumes that an invention-based system provides less reward on average than an innovation-based system would; this is perhaps arguable, but since it underies innovation-based proposals, I will go along with it.

17. See infra note 24-39 and accompanying text. 
emphasizing the reward function of patents at the expense of the disclosure function.

\section{B. Basic Requirements for a Patent}

The basic requirements for a patent reflect the dual functions of disclosure and reward. In general, the Umited States Patent Office grants a patent when an inventor can show three things: an invention is the first of its kind; it is useful; and it represents a nontrivial extension of what was known. ${ }^{18}$

Patent lawyers call the first-to-invent requirement "novelty." In practice, novelty is estabhished by applymg a set of techirical rules to determine if a patent applicant was really the first to make tlie invention that she claims. Lack of novelty may bar the claimed invention from being patentable eitlier because it was made before; it was sold more than a year before a patent application was filed; or it was otherwise subject to prior use or knowledge. ${ }^{19}$ The second requirement," "utility," has

18. 35 U.S.C. $\S \S 101$ (utility), 102 (novelty) and 103 (nonobviousness) (1982); see Graham v. John Deere Co., 383 U.S. 1, 12-19 (1966); see also 1 P. Rosenberg, PATENT LAW Fundamentals III-1 (1986). Two types of subject matter cannot be patented: mathematical formulas and natural laws, and products of nature. See 1 P. Rosenberg, supra, $\S 6.02$ [2]. Thus there is in effect a fourth requirement that an imvention not fall into one of these categories.

19. 35 U.S.C. $\S 102$ (1982). The crux of this section is that the mventor filing for a patent must be the first person to have made her particular invention. An invention is unpatentable under this section if it is precisely described in a printed publication or another patent prior to the patent applicant's date of invention, or if it is known or used by another in the United States prior to that date. Id. $\S \S 102(\mathrm{a}), 102(\mathrm{~g})$. In addition to these sources, a U.S. patent application can anticipate (i.e., gain priority over) an invention, even though such applications are kept secret, as long as the application eventually results in an issued patent and it is filed prior to the second inventor's date of invention. Id. $\S 102$ (e) (anticipation by prior-filed U.S. patent application); see also id. §120 (secrecy of patent applications). Note that where the anticipatory apphication not ouly describes the invention but also claims it, the application will not automatically disqualify the other inventor's patent; instead, an administrative proceeding known as an "interference" will be conducted to determine which apphicant invented first. Id. $\S 135$. See 1 D. ChIsum, PATENTs $\S 3.07$ (1986, 1987 rev.) (describing practice of proving date of imvention prior to date of a patent apphication, and noting that only interference is proper to resolve invention date disputes for applications claiming same subject matter). See generally id. $\S 10.02$ (role of interference proceedings in establishing priority).

Section 102 also describes certain actions of an inventor or others that may bar the issuance of a patent, such as public use or sale of the invention more than one year before a patent application ( 35 U.S.C. $\S 102(\mathrm{~b})(1982)$ ), abandonment, (Id. $\S 102(\mathrm{c})$ ) or filing a foreign application more than a year before filing a U.S. application covering the same invention, (Id. $\S 102(d)$ ). See 2 D. CHISUM, supra $\S 6$ ("Statutory Bars").

The essential elements of an invention are defined in the portion of the patent known as the "claims"; the novelty requirement ineans the claims in a patent must describe a new invention. The claims are critical, since they mark off the patentee's property rights; they specify precisely the inetes and bounds of the invention and therefore carve the invention out froin what went before-from the "prior art," in patent terminology. See In re Bass, 474 F.2d 1276, 177 U.S.P.Q. (BNA) 178 (C.C.P.A. 1973) (description of prior art in a machine patent case); 2 D. CHISUM, supra $\$$ 5.03[1][a] (examining the doctrine of analogous and nonanalogous art with regard to prior art determination); Janicke, What is "Prior Art" Under Section 103? The Need For Policy Thought, in 
devolved over the years into a rather minimal obstacle to obtaining a patent. Today, a patent will not be withheld even though the invention works only in an experimental setting, and has no proven use in the field or factory. ${ }^{21}$

The final requirement, nontriviality, or "nonobviousness," is the most important requirement; it has been called "the ultimate condition of patentability."23 This is because nonobviousness attempts to measure an even more abstract quality than novelty or utility: the technical accomplishment reflected in an invention. This requirement asks whether an invention is a big enough technical advance; even if an invention is new and useful, it will still not merit a patent if it represents merely a trivial step forward in the art. This is why nonobviousness is the final gatekeeper of the patent system.

The test of nonobviousness has a long history, and it is difficult to understand its role in patent law without some knowledge of this historical background. Accordingly, I will attempt a short summary. ${ }^{24}$ Prior to 1850 , courts tested only for novelty and utility. ${ }^{25}$ However, in 1850 the Supreme Court in Hotchkiss v. Greenwood denied a patent for applying an old method of making wood cabinet knobs to the making of clay knobs, finding the process lacked "that degree of skill and ingenuity which constitute essential elements of every invention."26 By 1875, the Court adopted the Hotchkiss language and the added hurdle to patenta-

Nonobviousness-The Ultimate Condition of Patentability 5:101-5:111 (J. Witherspoon ed. 1980) [hereinafter WrrHERSPOON, NoNobviousNess] (arguing for a narrower and clearer statutory standard for prior art).

Patent claim drafting and construction is an arcane specialty. See, e.g., A. DeLler, PATENT Claims (2d ed. 1971 \& Supp. 1987) (3 vols.).

20. "Whoever invents any new and useful process, machine, manufacture, or composition of matter . . may obtain a patent therefor . . ." 35 U.S.C. $\$ 101$ (1982) (emphasis added).

21. See, e.g., Curtiss-Wright Corp. v. Link Aviation, Inc., 182 F. Supp. 106, 123, 124 U.S.P.Q. (BNA) 266, 280 (N.D.N.Y. 1959). Courts also have consistently held that a new-found use, discovered after the patent application is filed, may be considered in determining whether the utility requirement has been met. See, e.g., Indiana General Corp. v. Lockheed Aircraft Corp., 408 F.2d 294, 298-99, 160 U.S.P.Q. (BNA) 6, 9 (9th Cir. 1968). In chemical patent cases, however, the courts have consistently held that a chemical compound claimed in a patent application must have some known, practical use. Some commentators have argued that this is overly restrictive, since some compounds, such as intermediate products of long chemical reactions, can lead to useful results further along the path of a chemical reaction. See Mirabel, "Practical Utility" is a Useless Concept, 36 AM. U.L. REV. 811, 822-23 (1987); Comment, The Patentability of Chemical Intermediates, 56 CALIF. L. REv. 497, 510-14 (1968).

22. 35 U.S.C. $\S 103$ (1982) (entitled "Conditions for patentability; nonobvious subject matter"); see WITHERSPOON, NONOBVIOUSNESS, supra note 19, at vii-viii.

23. WITHERSPOON, NONOBVIOÚSNESS, supra note 19.

24. For a more extensive history, see Kitch, Graham v. John Deere Co.: New Standards for Patents, 1966 SuP. CT. REv. 293.

25. See Kitch, supra note 24, at 304. See generally Mintz, The Standard of Patentability in the United States-Another Point of View, 1977 DET. C.L. REv. 755, 763 (1977).

26. 52 U.S. (11 How.) 248, 267 (1850). 
bility it implied; liencefortl, mventions liad to embody some degree of "skill and ingenuity," or inventiveness. ${ }^{27}$

As time went on, it became clear tliat tlie judge-made test of invention was highly abstract; judges tended to phrase it differently and apply it unevenly in various cases. It is thus not surprising that the patent community welcomed the general recodification of patent law in 1952 as an opportunity to clarify this test. ${ }^{28}$ Section 103 of the 1952 Act was the first formal attempt to structure judicial thinking about obviousness. It reads:

A patent may not be obtained [even though the invention is novel under $\S 102$ of the Act], if the differences between the subject matter sought to be patented and the prior art are such that the subject matter as a whole would have been obvious at the time the invention was made to a person having ordinary skill in the art to which said subject matter pertains. ${ }^{29}$

On its face, Section 103 appears to give the invention test a more solid footing. It supplies both a yardstick to compare the invention witl- - the whiole of the prior art-and a fictional artisan-the person "skilled in the art"- to apply that prior art to the problein addressed in the patent. By contrast, the old invention test asked wliether the invention contained that special quality which made a new thing patentablewhat one court called "that impalpable soniething." 30 The essence of the statutory test is that it provides a frame of comparison: It tells the judge what to look at, and froin which perspective, in order to determine if the invention is obvious.

Initially, however, anbiguities surrounding the statute's passage made it unclear whether the 1952 Act had actually changed the standard of nonobviousness or simply restated pre-1952 law. ${ }^{31}$ Some federal cir-

27. See Kitch, supra note 24 , at 318-19 (concluding that the invention test was actually added to patent law when the Court applied the Hotchkiss holding in Collar Co. v. Van Dusen, 90 U.S. (23 Wall.) 530 (1875)); see also Mintz \& O'Rourke, The Patentability Standard in Historical Perspective: "Invention" to Section 103 Nonobviousness, in WITHERSPOON, NONOBVIOUSNESS, supra note 19, at 2:201, 2:204-2:206 (describing acceptance of invention requirement by the courts).

28. See Edell, The Supreme Court and Section 103, 5 AM. PAT. L.A.Q.J. 99, 100 (1977) (Supreme Court cases of 1940 s and early 1950s heightened "confusion" over invention test and "led the patent bar to seek legislative redress and a statutory definition of 'invention" "); Rich, Why and How Section 103 Came To Be, in WrTHERSPOON, Nonobviousness, supra note 19, at 1:201, 1:208 (in the wake of Snpreme Court cases in the 1940s, and the general confusion over what invention ineant, "the atmosphere [had] become charged up with discontent like a thunderstorm."); see also Rich, The Vague Concept of "Invention" as Replaced by Section 103 of the 1952 Patent Act, in WITHERSPOON, Nonobviousness, supra note 19 at 1:401 (1952 Patent Act resulted from Supreine Court opinions further muddying concept of invention, and Congressional hearings on possible solutions).

29. 35 U.S.C. $\$ 103$ (1982).

30. McClain v. Ortinayer, 141 U.S. 419, 427 (1891).

31. See Rich, Congressional Intent-Or, Who Wrote the Patent Act of 19522, in WrTHERSPOON, NoNOBVIOUSNESS, supra note 19, at 1:1, 1:11-1:12 (discussing absence of Congressional debate). Whether $\S 103$ is characterized as a clarification or as the next step in the evolution of the invention 
cuits thought there had been no change; others disagreed. ${ }^{32}$

The Supreme Court finally addressed the issue in the 1966 case of Graham v. John Deere. ${ }^{33}$ The John Deere Company had found that placing a himge in the shank of a plow (the thick part that goes deepest in the ground) prevented the plow from being damaged by rocks and other debris, and had filed for a patent on its invention. The Court, finding that the basic idea of a hinge was an old one in the art, held the Deere patent invahid.

More important than the patent at issue was the Court's approach to the question of obviousness. While Justice Clark's majority opinion did not exphicitly resolve the dispute in the circuit courts, ${ }^{34}$ his emphasis on the language of the 1952 Act was widely interpreted as a ruling that Section 103 had superseded the imvention requirement: ${ }^{35}$

[T]he $\S 103$ condition . . . lends itself to several basic factual inquiries. Under $\S 103$, the scope and content of the prior art are to be determined; differences between the prior art and the claims at issue are to be ascertained; and the level of ordmary skill in the pertinent art resolved. Against this background, the obviousness or nonobviousness of the subject matter is determined. ${ }^{36}$

concept, commentary by the authors of the 1952 Act shows that it was intended to end the confusion surrounding the invention requireinent. See Federico, Origins of Section 103, 5 AM. PAT. L.A.Q.J. 87 (1977), in WITHERSPOON, NoNoBviousNess, supra note 19, at 1:101; Rich, Why and How Section 103 Came to $B e$, in id. at 1:201.

32. See Comment, The Standard of Patentability-Judicial Interpretation of Section 103 of the 1952 Patent Act, 63 CoLUM. L. REv. 306, 313-23 (1963) (reviewing opinions of circuit courts, concluding that the Second, Third, Fourth, and District of Columbia Circuits had interpreted $\S 103$ as relaxation of the standard of patentability; the First, Fifth, Sixth, Eighth, and Ninth Circuits had interpreted $\S 103$ as only codification of prior case law; and the Seventh and Tenth Circuits had taken no discernible position on the issue).

33. 383 U.S. 1 (1966). United States v. Adams, 383 U.S. 39 (1966).

34. Even though Justice Clark enphasized that $\S 103$ was the basis of the three-part test, he noted that the statute had not in any way altered the standard of patentability. It was "intended inerely as a codification of judicial precedents embracing the Hotchkiss condition . . . " Graham, 383 U.S. at 19.

35. See, eg., 1 D. Dunner, J. Gambrell, M. Adelman \& R. Lipsey, Patent Law Perspectives $\S 2.6[2 .-1-2]$, at 2-414 (1970 \& rev. 1988) ("Confirmation that [\$ 103] was wiping out the dread disease [of the old standard of invention] . . . seemed clearly established with Justice Clark's disposition of the case."); Rich, Laying the Ghost of the Invention Requirement, in WITHERSPOON, NoNobviousNess, supra note 19 at 1:501, 1:514 ("The nost iniportant question answered in Graham was whether Seetion 103 replaced 'invention' as a test for patentability, so that it is legally dead. The answer is 'Yes'."); see also Edell, supra note 28, at 106-07 (quoting Rich, supra).

36. Graham, 383 U.S. at 17. Sone observers appear to think that the Graham decision, like most of the events leading up to replacenient of the invention requireinent, was the product of the patent bar rather than outside institutious such as Congress or the courts. See, e.g., 1 Hearings Before the Commission on Revision of the Federal Court Appellate System (Second Phase), 93rd Cong., 2d Sess. 266 (1974) ("Hruska Commission") (testimony of Professor Irving Kayton, George Washington University, that the Graham decision was "a classic because [Justice Clark's] law clerk was a patent lawyer"). 
The decision marked the beginning of a new era in patentability, signifying the end of the confusing reign of Hotchkiss v. Greenwood. The patent bar concluded hopefully that the new standard of nonobviousness was here to stay. ${ }^{37}$

Thus the modern interpretation of nonobviousness turns on the Graham three-part test, requiring a judge to: (1) determine the state of the "prior art" before the imvention; (2) assess the ordinary level of skill in the inventor's field; and (3) examine the differences between the invention and the prior art. ${ }^{38}$ The Federal Circuit has made Graham-along with the secondary considerations discussed in the next section-the cornerstones of nonobviousness.

Arguably, by emphasizing Graham, the Federal Circuit has had to ignore several subsequent Supreme Court cases. ${ }^{39}$ These post-Graham cases, however, involved the tangential issue of special requirements for

37. See, e.g., D. DunNer, supra note 35, at 2-414; see also Kayton, This Year (1966) in Patent Law, 35 GEO. WASH. L. REv. 720, 721 (1967).

38. Graham, 383 U.S. at 17. Regarding the second part of the test, recent cases have held that the "skilled person in the art" means those responsible for most of the inventions in an industry. See, e.g., Orthopedic Equip. Co. v. Urited States, 702 F.2d 1005, 1011-12, 217 U.S.P.Q. (BNA) 193, 198-99 (Fed. Cir. 1983); Jacobsen Bros. Inc., v. United States, 512 F.2d 1065, 1070-71, 185 U.S.P.Q. (BNA) 168 (Ct. Cl. 1975) (adopting opinion originally published in 184 U.S.P.Q. (BNA) 181, 185); see also Environmental Designs, Ltd. v. Union Oil Co., 713 F.2d 693, 696, 218 U.S.P.Q. (BNA) 865, 868 (Fed. Cir. 1983), cert. denied, 464 U.S. 1043 (1984), where the court provided a list of factors relevant to a determinatiou of the level of skill in the art:

(1) educational level of the inventor;

(2) type of problems encountered in the art;

(3) prior art solutions to the problems;

(4) rapidity with which innovations are made;

(5) sophistication of the technology; and

(6) educational level of active workers in the field.

Cf. Ebert, Superperson and the Prior Art, 67 J. PAT. OFF. Soc'Y 657 (1985) (proposing that courts' presumption that skilled artisan knows everything in a field should be restricted by taking account of cognitive limitations of real people).

39. The Supreme Court decided two patent cases after Graham that referred to the old invention test, but both involved the distinct issue of "combination patents." Despite some problematic language in these cases, the patent bar concluded that they did not signify any retrenchment from the principles of Graham. The Court in these cases reaffirmed the evasive "synergism" test for combination patents, which required an unexpected result or effect to flow from a combination of old components or techniques. If the combination failed to exhibit any properties beyond what might be expected, no patent would issue. See Sakraida v. Ag Pro, Iuc., 425 U.S. 273 (1976); Anderson's-Black Rock, Inc. v. Pavemeut Salvage Co., 396 U.S. 57 (1969).

In Anderson's-Black Rock, the invention at issue was a paving machine containing a heating element to make smooth seams between adjoining strips of pavement. The Supreme Court invalidated the patent on the machine because the aggregation of old teehniques lacked synergisn: The new combination worked just as one would predict, given what was known about its individual conponents. 396 U.S. at 62-63. Sakraida presented similar facts. The patent covered a customized barn for dairy cows, with sloped floors and water storage tanks to make waste cleanup simpler. 425 U.S. at 274. The Supreme Court reiterated the synergism principle in these words:

Though doubtless a matter of great convenience, producing a desired result in a cheaper and faster way, and enjoying conmercial success, the [pateutee] "did not produce a "new or different function' ... within the test of validity of combination patents." Anderson'sBlack-Rock Paventent Co. [396 U.S.] at 60 ... These desirable benefits "without invention 
so-called combination patents. Their effect on the nonobviousness requirement in general is therefore somewhat uncertain. Even more importantly, the Federal Circuit has rationalized and stabilized the law in this area by einphasizing Graham. The three-part test seems to make too much sense to abandon it because of the subsequent cases.

II

\section{COMMERCIAL SUCCESS AND OTHER SECONDARY CONSIDERATIONS}

\section{A. Origins of the Secondary Considerations}

As we have seen, the Court in Graham structured a three-part test for determining patentability. In addition, the Court expressly approved the use of "secondary" or "objective" considerations; that is, it authorized courts to look at evidence outside the mtrinsic features of the invention and focus on the real-world circumstances surrounding its origin and commercialization. ${ }^{40}$ Courts had already begun to consider these factors in determining patentability before the Graham case. Over time, this approach grew in popularity; today nonintrinsic evidence is referred to as the "secondary" or "objective" considerations, and it occupies an increasingly important place in nonobviousness determinations. While secondary considerations vary, the ones courts most cominonly examine are the commercial success of the invention (the inost inportant secondary consideration), the extent of hicensing, immediate copying by competitors, failure of others to make the same invention, and a long-felt need for the invention. ${ }^{41}$

will not make patentability." A. \& P. Tea Co. v. Supermarket Corp., 340 U.S. [147] at 153

....

Id. at 282-83.

The reference to the $A$. \& $P$. case was especially disappointing to those who saw Graham as the end of antipatent sentiment in the Supreme Court, since $A$. \& $P$. was widely thought to represent the inost unreasonable application of the synergisin requiremeut. Some patent lawyers even feared that the Court was once again establishing a very high standard of patentability for all inventions. See, e.g., 1 D. Dunner, J. Gambrell, M. Adelman \& C. Lipsey, Patent Law Perspectives $\S 2.6[2 .-1-1]$, at $2-414$ to $2-415$ (1986) (" $A \& P$ represented the culınination of subjective, hindsightridden and inconsistent judicial determinations of what is "an invention" "). Even more frustrating for patent lawyers, the decisive impetus behind the drafting of $\S 103$ had been the desire to obviate the effects of the A.\&P. decision. See Rich, Congressional Intent-Or, Who Wrote the Patent Act of 1952?, in WITHERSPOON, NoNOBVIOUSNESS, supra note 19, at 1:1, 1:7-1:8.

40. Graham v. John Deere, 383 U.S. 1, 17-18 (1966).

41. See 2 D. ChISUM, supra note $19, \S 5.05$. Chisuin, in keeping with other commentators, also adds a number of less significant factors to the list of secondary considerations that courts have contemplated at one time or another, including: ( 1 ) invention produced results that were unexpected by those in the art, or that ran contrary to the tcachings of the prior art; (2) progress of the patent application through the Patent Office; and (3) praise for the invention from those skilled in the art. Id.; see also Harris, Apparent Federal Circuit Standards for Weighing Nonobviousness Argument that Prior Art Reference Teaches Away from Present Invention, 70 J. PAT. \& TRADEMARK OFF. Soc'y 79 (1988); Walker, Objective Evidence of Nonobviousness: The Elusive Nexus Requirement (Part I), $69 \mathrm{~J}$. 
A significant number of Supreme Court cases decided after Hotchkiss v. Greenwood in 1850 touch on the secondary considerations. From the first decision that mentions them in $1876^{42}$ until the 1930s, the Court gave these considerations a generally favorable reception. Where more than one objective factor was present-for example, commercial success and failure of others to make the same imvention-the Court tended to uphold the patent agamst a challenge that it lacked invention. ${ }^{43}$ This was especially true where the patentee's product displaced those of competitors. ${ }^{44}$

Usually commercial success was the most important secondary consideration in the Court's opimion. ${ }^{45}$ The Court, however, was less than clear concerning what type of evidence-for example, sales data or market share-was needed to estabhish commercial success. ${ }^{46}$ Moreover, several cases that did mention success treated its relevance inconsistently. For example, while some cases from the 1890 s gave commercial success a himited role, using it only to "tip the scale" when other facts regarding patentability were equally balanced, ${ }^{47}$ another case from the same decade

Pat. \& TRademark OFF. Soc'y 175, 175 (1987) [hereinafter Walker, Nexus Part $I$ ]. In the past, courts considered the near simultaneous invention by multiple mventors proof that an invention was obvious under 35 U.S.C. $\S 103$, but more recent decisions have called this assumption into question. Compare 2 D. Chisum, supra note $19, \S 5.05[7]$ (near simultaneous solution tends to show the solution was obvious) with Environmental Designs, Ltd. v. Union Oil Co., 713 F.2d 693, 698 n.7, 218 U.S.P.Q. (BNA) 865, 869 n.7 (Fed. Cir. 1983) (virtually simultaneous making of same invention does not preclude patentability), cert. denied, 464 U.S. 1043 (1984).

42. See, e.g., Sinith v. Goodyear Dental Vulcanite Co., 93 U.S. 486, 494-96 (1876); Goodyear Tire \& Rubber Co. v. Ray-O-Vac Co., 321 U.S. 275, 279 (1944).

43. See Diamond Rubber Co. v. Consolidated Rubber Tire Co., 220 U.S. 428, 441 (1911); Krementz v. S. Cottle Co., 148 U.S. 556, 560-61 (1893); Topliff v. Topliff, 145 U.S. 156, 164 (1892). Equities, of course, sometimes played a role as well. An extreme example of the Court's concern with the equities of a case was in Smith, 93 U.S. at 489-92, where the Court recounts in detail the inventor's heroic struggle to bring a better pair of dentures to the American consumer: "His ill health interfered with his working successfully in the line of his profession, and his fainily was subjected to great privations. He borrowed, sometimes, small sums to purchase underclothing for himself." Id. at 491.

44. See Eibel Process Co. v. Minnesota \& Ontario Paper Co., 261 U.S. 45, 56 (1923); Minerals Separation Ltd. v. Hyde, 242 U.S. 261, 270 (1916); Carnegie Steel Co. v. Cambria Iron Co., 185 U.S. 403, 442-43 (1902); Magowan v. New York Belting \& Packing Co., 141 U.S. 332, 343 (1891); Loom Co. v. Higgins, 105 U.S. 580, 591 (1882).

45. See, e.g., Goodyear Tire \& Rubber Co. v. Ray-O-Vac Co., 321 U.S. 275, 279 (1944); Potts v. Creager, 155 U.S. 597, 609 (1895); Grant v. Walter, 148 U.S. 547, 556 (1893); Krementz v. S. Cottle Co., 148 U.S. 556, 560-61 (1892); The Barbed Wire Patent, 143 U.S. 275, 292 (1892); Smith v. Goodyear Dental Vulcanite Co., 93 U.S. 486, 495-96 (1876).

46. See, e.g., Potts v. Creager, 155 U.S. 597, 609 (1894) (evidence that device has gone into general use and displaced other similar devices is sufficient to confirm patentability); Grant $v$. Walter, 148 U.S. 547, 556 (1893) (patented device gone into general use is evidence of utility); The Barbed Wire Patent, 143 U.S. 275, 292 (1892) (crediting the patent applicant with presenting practical purpose to public, who "eagerly seized upon" it); $c f$. McClain v. Ortmayer, 141 U.S. 419 (1891) (coininercial success attributable to advertising).

47. See, e.g., Potts v. Creager, 155 U.S. 597, 609 (1895); Grant v. Walter, 148 U.S. 547, 556 (1893). 
took the opposite view, stating, in dictuin, that success was "always relevant" to the issue of patentability. ${ }^{48}$ Despite this difference, however, the early cases imvolving commercial success were mostly consistent; they relied on commercial success in finding patents valid.

The Courts' treatment of secondary factors changed after the 1930s, when the antimonopoly sentiments of the New Deal began to find expression in the Supreme Court's statements about the monopolistic effects of patents. ${ }^{49}$ Between 1931 and 1976, the Court invalidated the vast majority of patents that came before it, including all but two that were supported with secondary consideration evidence. ${ }^{50}$ One statement in a 1949 case, echoed in several subsequent opimions, exemplifies the Court's view of secondary considerations during this period: "Where . . invention is plainly lacking, commercial success caimot fill the void."51

48. Keystone Mfg. Co. v. Adams, 151 U.S. 139, 143 (1894) (upholding a patent on a cornhusking machine, stating that general use-commercial success-"is always of importance, and is entitled to weight, when the question is whether the machme exhibits patentable invention").

49. See, e.g., Great Atl. \& Pac. Tea Co. v. Supermarket Equip. Corp., 340 U.S. 147 (1950) (patent struck down for lack of invention); Jungerson v. Ostby \& Barton Co., 335 U.S. 560 (1949) (striking down patent for lack of invention); id. at 572 (Jackson, J., dissenting) ("[T] he only patent that is valid is one which this Court has not been able to get its hands on."); Cuno Eng'g Corp. v. Autonatic Devices Corp., 314 U.S. 84, 91 (1941) (adopting higher standard of invention, based on patents and copyrights clause of the Constitution, and stating in dictum that "a flash of creative genius" is required for an invention to be patentable).

Justice William O. Douglas seemed especially suspicious of patents. See, e.g., Automatic Radio Mfg. Co. v. Hazeltine Research, Inc., 339 U.S. 827, 839 (1950) (Douglas, J., dissenting) ("But what worse enlargeinent of monopoly is there than the attachment of a patent to an unpatentable article? When we consider the Coustitutional standard [of invention], what greater public harm than that is there in the patent system ... ?"); see also Baun, The Federal Courts and Patent Validity: An Analysis of the Record, 56 J. PAT. OFF. Soc'Y 758, 773 (1974) ("With the coming of the New Deal ... the political climate became less hospitable to the patent system."); W. HAMILTON, PATENTS aND Free ENTERPRISE, Monograph No. 31 (Tenp. Nat'l Economic Comm.), 77th Cong., 1st Sess. (1941) (pointing to corporate abuses of patents and stressing system's contribution to monopoly).

50. According to figures presented in Baum, supra note 49, the Court considered fifty-nine patent cases between 1931 and 1973. It invalidated patents in forty-nine, or 83\%, of these cases. Id. at 777. The two cases after 1973 also resulted in rulings of invalidity. See Sakraida v. Ag Pro, Inc., 425 U.S. 273 (1976); Dann v. Johnston, 425 U.S. 219 (1976). Many of these cases included sccondary consideration evidence of patentability; in soine, it was merely disregarded, see, e.g., Paramount Publix Corp. v. American Tri-Ergon Corp., 294 U.S. 464, 474-76 (1935) (invalidating patent despite evidence of commercial success); Altoona Publix Thcatres, Inc. v. Anerican TriErgon Corp., 294 U.S. 477, 487-88 (1935) (same); while in others, it was discarded in sweeping language, see infra note 51 and accompanying text.

The two exceptions were Goodyear Tire \& Rubber Co. v. Ray-O-Vac Co., 321 U.S. 275, 279 (1944) (upholding patent partly on basis of long-felt need, supported by showing of commercial success), and United States v. Adams, 383 U.S. 39 (1966), decided together with Graham v. John Deere Co., 383 U.S. 1 (1966) (upholding validity of patent where prior art "teaches away" from patentee's solution, and where invention achieved surprising results, but noting wide scale adoption of patentee's invention and its commercial success).

51. Jungersen v. Ostby \& Barton Co., 335 U.S. 560, 567 (1949); see also Sakraida v. Ag Pro, Inc., 425 U.S. 273, 282 1976) ("Though doubtless ... enjoying conımercial success," patented item did not rise to the level of invention.); Great Atl. \& Pac. Tea Co. v. Supermarket Equip. Corp., 340 U.S. 147, 153 (1950) ("Commercial success without invention will not make patentability."); Cuno 
Notwithstanding the Court's general hostility toward patents, Graham provided at least one bright spot. ${ }^{52}$ Even though the Court invalidated the patent in Graham, it explicitly approved the use of secondary considerations in conjunction with its three-part test for nonobviousness: "secondary considerations . . . might be utilized to give light to the circumstances surrounding the origin of [the invention]," the Court said; "[A]s indicia of obviousness or nonobviousness, these inquiries may lave relevancy." 53 Despite this approval, however, in several subsequent cases the Court reeinpliasized that at least one secondary consideration, cominercial success, could not establish patentability by itself. ${ }^{54}$ Thus in the last two cases decided before the formation of the Federal Circuit, the Court was careful to prevent technical obviousness from being submerged by the secondary considerations. ${ }^{55}$

\section{B. The Federal Circuit and Secondary Considerations}

Federal Circuit opimions give the impression that Graham was the last Supreine Court case to mention secondary considerations. This no doubt stems in part from the fact that unlike Graham, subsequent cases liave not contained a clear statement of the nonobviousness test; but it also reveals tlie court's intention to put its own stainp on patent law. The court lias openly disparaged lower court opimions referring to the postGraham cases, ${ }^{56}$ and lias even elevated the secondary considerations of

Eng'g Corp. v. Automatic Devices Corp., 314 U.S. 84, 94 (1941); accord Boyer, Commercial Success as Evidence of Patentability, 37 FORDHAM L. REv. 573, 585 (1969) (of the 180 patent cases decided by federal courts between 1942 and 1951, only 60 express approval of commercial success as an indication of patentability).

52. 383 U.S. 1 (1966). See supra notes 33-39 and accompanying text for a detailed discussion of the case.

53. Graham, 383 U.S. at $17-18$.

54. Sakraida, 425 U.S. at $282-83$.

55. See H. Ullrich, Standards of Patentability for EuRopean Inventions 85-86, 89-91 (IIC Studies in Industrial Property and Copyright Law No. 1, 1977) (summarizing state of U.S. law in comparative survey of patentability standards).

56. See Stratoflex, Inc. v. Aeroquip Corp., 713 F.2d 1530, 218 U.S.P.Q. (BNA) 871 (Fed. Cir. 1983). In his discussion of the lower court's opinion, Chief Judge Markey, writing for the court, made this illunimating statenient:

[The judge below] naade findings on secondary considerations but said she did not include then in her analysis because she believed the claimed inventions were plainly obvious and "those matters without invention will not nake patentability" [quoting from Anderson's Black Rock, Inc. v. Pavement Salvage Co., 396 U.S. 57, 63 (1969), which was cited by the trial judge] and should be considered only in a close case. That was error.

The error may have arisen from the circuity of the slogan oft-cited as a basis for exclusion [of such evidence]. In the slogan as here stated: "those nuatters" is a synonynu for "evidence of nonobviousness;" the issue is "nonobviousnesness" not "invention;" and patentability here is a synonym for "nonobviousness." Thus the slogan reads "evidence of nonobviousness without nonobviousness will not make nonobviousness."

Id. at 1539, 218 U.S.P.Q. at 879; see also Kansas Jack, Inc. v. Kuhn, 719 F.2d 1144, 1150, 219 U.S.P.Q. (BNA) 857, 861 (Fed. Cir. 1983) (lower court statenient that "commercial success without 
Graham to a fourth element of the test for nonobviousness. ${ }^{57}$ If the basis for the Federal Circuit's imterpretation of Supreme Court precedent is unclear, the result is not. The secondary considerations have become more important. In some cases, for example, commercial success (still the most important secondary consideration) has been the decisive factor supportimg patentability. ${ }^{58}$

The change has come swiftly, if rather quietly. In principle, the new court merely "inherited" the case law of its predecessor courts, the Court of Customs and Patent Appeals (the "CCPA") and the old Court of Claims. ${ }^{59}$ But even a cursory look at the decisions of its predecessors reveals that neither court went nearly as far as the Federal Circuit has gone in enhancing the importance of commercial success and other secondary factors. ${ }^{60}$

To grasp the inagnitude of the Federal Circuit's doctrinal innova-

invention will not make patentability" was "flawed") (citing Stratoflex). In neither case did the Federal Circuit cite the Supreme Court opinion from which the trial court had drawn its language.

57. See Bausch \& Lomb, Inc. v. Barnes-Hind/Hydrocurve, Inc., 796 F.2d 443, 446-47, 230 U.S.P.Q. (BNA) 416, 419 (Fed. Cir. 1986) (Secondary considerations are one of the "four inquiries mandated by [the] Graham [decisionl."), cert. denied, $108 \mathrm{~S}$. Ct. 85 (1987); see also Cable Elec. Prods., Inc. v. Genmark, Inc., 770 F.2d 1015, 1026, 226 U.S.P.Q. (BNA) 881, 881 (Fed. Cir. 1985) (evidence on secondary factors must be considered even when the thrce Graham indicia point clearly to one conclusion); Simmons Fastener Corp. v. Illinois Tool Works, Inc., 739 F.2d 1573, 1575, 222 U.S.P.Q. (BNA) 744, 746 (Fed. Cir. 1984) (inquiry under Graham includes reviewing evidence of secondary factors, when present), cert. denied, 471 U.S. 1065 (1985); Stratoflex 713 F.2d at 1539, 218 U.S.P.Q. at 879 (Fed. Cir. 1983) (under Graham, obviousness inquiry must include secondary factor evidence, with each giveu "its appropriate weight").

58. See infra notes 95-104 and accompanying text.

I do not mean to suggest that the Supreme Court is no longer the last word on matters of patent law. The operational fact, however, is that one of the Federal Circuit's primary concerns is patent cases; the Supreme Court very rarely takes a patent case. In the October 1986 Term, the Court vacated and remanded one opinion from the Federal Circuit. Dennison Mfg. Co. v. Panduit Corp., 475 U.S. 809 (1986), vacating and remanding 774 F.2d 1082, 227 U.S.P.Q. (BNA) 337 (Fed. Cir. 1985), cert. denied, 107 S. Ct. 2187 (1987). It was the first time the Supreme Court had passed on a substantive issue in patent law since the Federal Circuit's formation in 1982. Beforc that, the last patent case decided by the Court was Diamond v. Chakrabarty, 447 U.S. 303 (1980) (patentability of micro-organism). While it is too early to tell whether the Supreme Court will continue to pay so little attention to Federal Circuit decisions, it is perhaps worth noting that historically the Supreme Court has felt some obligation to oversee the development of patent law, if only infrequently. See Harris, Prospects for Supreme Court Review of the Federal Circuit Standards for Obviousness of Inventions Combining Old Elements, 68 J. PAT. \& TRAdEMARK OFF. SOC'Y 66, 66 (1986).

59. See Lever, The New Court of Appeals for the Federal Circuit (Part I), 64 J. PAT. OFF. Soc'Y 178, 178 (1982). The Federal Circuit adopted as its own the precedents of the CCPA and Court of Claims in South Corp. v. United States, 690 F.2d 1368, 1370, 215 U.S.P.Q. (BNA) 657, 658 (Fed. Cir. 1982).

60. The CCPA, for example, initially refused to admit evidence of commercial success unless the question of patentability-that is, nonobviousness-was a close one. See, e.g., In re Sola, 77 F.2d 627, 630 (C.C.P.A 1935); In re Farrand, 49 F.2d 1035, 1038 (C.C.P.A. 1931); In re Ackenbach, 45 F.2d 437, 440 (C.C.P.A. 1930). Later cases withdrew somewhat from this position, but still expressed a guarded skepticism about commercial success. See In re Felton, 484 F.2d 495, 500, 179 U.S.P.Q. (BNA) 295, 299 (C.C.P.A. 1973); In re Tiffin, 443 F.2d 394, 400, 170 U.S.P.Q. (BNA) 88, 93 (C.C.P.A. 1971). 
tions in this area, it is important to understand the full range of the court's secondary considerations jurisprudence. This section reviews the current state of the law in both its substantive as well as its evidentiary and procedural aspects. To illustrate the Federal Circuit's impact, however, it will be useful to understand the history of the court itself.

\section{Origins of the Federal Circuit}

The Federal Circuit was created by the Federal Courts Inproveinent Act of 1982.61 It was the product of a long debate over the need for a specialized appellate court to handle patent cases. ${ }^{62}$ Those arguing for a court of special jurisdiction pointed to the inconsistent and sometimes confused opinions of the regional circuits, ${ }^{63}$ while others expressed fear that a specialty court would be captive to the patent bar and would therefore fail to serve the wider social interest. ${ }^{64}$ Of course, proponents of a specialized court did hope to get a court that was more pro-patent as well as inore consistent. ${ }^{65}$

The Federal Courts Improvement Act was a comproumse solution. It gave the Federal Circuit jurisdiction not only over patent appeals, but also over appeals froin the U.S. Claims Court, the Court of International Trade, and the Merit Systein Protection Board, among others. ${ }^{66}$ The court was originally staffed not only with several patent-experienced judges froin the old CCPA, but also with nonpatent judges from that court and the Court of Claims. ${ }^{67}$ Moreover, presumably to prevent the patent-experienced judges from dominating patent cases, the Act

61. Pub. L. No. 97-164, $§ 101,96$ Stat. 25 (codified in scattered sections of 28 U.S.C. (1982 \& Supp. III 1986)).

62. See Lever, supra note 59, at 186-197 (history of the Act).

63. Id. at 197-200.

64. See, e.g., Commission on Revision of THE Federal CoURt ApPellate System, STRUCTURE AND INTERNAL PROCEDURES: RECOMMENDATIONS FOR CHANGE (1975), reprinted in 67 F.R.D. 195, at 234-36 ("[T] he Coinmission has concluded that, on balance, specialized courts [including one for patents] would not be a desirable solution either to the problems of the national law or . . . to the problems of regional court caseloads." Id. at 234); Rifkind, A Specialized Court for Patent Litigation: The Danger of a Specialized Judiciary, 37 A.B.A. J. 425 (1951) (advocating that judges be immersed in all aspects of the law, not forced into the sterility of a specialized bench); $c f$. Rifkind, The Romance Discoverable in Patent Cases, 37 J. PAT. OFF. Soc'y 319 (1955) (arguing that patent cases are no more complex or uninteresting than any other litigation).

65. Between 1921 and 1973 the circuit courts found nearly two-thirds of adjudicated patents invalid. Baum, The Federal Circuits and Patent Validity: An Analysis of the Record, 56 J. PAT. OFF. Soc'y 758, 760 (1974). In some circuits, courts practically never upheld patents. See id. at 762 (Between 1961. and 1973, the Eighth Circuit invalidated 89\% of patents).

66. Federal Courts Improvement Act of 1982, $\S 127,28$ U.S.C. 1295 (1982).

67. Id. $\S 165,28$ U.S.C. $\S 44$ note (1982) (on continued service of judges). To msure the continuation of this balance, the Federal Courts Improvement Act "suggest[ed] that the President, in nominating individuals to judgeships on the [CAFC and U.S. Claims Court] . . select froin a broad range of qualified individuals." Id. $\S 168,28$ U.S.C. $\S 44$, note (1982) (on appointment of judges). 
requires judges to rotate among panels so that all judges "sit on a representative cross-section of the cases heard."68 Finally, the Act contains a number of provisions designed to insure uniformity in the Circuit's opinions, and perhaps thereby reduce the influence of the patent judges: These include allowing panels of more than three judges, ${ }^{69}$ and permitting circuits to hire "technical advisors" to help with consistency checks. $^{70}$

Even with these safegnards, however, the Federal Circuit appears to be a "pro-patent" court. Between 1982 and 1985, the court invalidated only forty-four percent ${ }^{71}$ of the patents it adjudicated on appeal from trial courts, a inarked contrast to the old invalidation rate of approximately sixty-six percent. ${ }^{72}$ Perhaps more importantly, patent lawyers believe the court favors patentees-and presumably advise their clients accordingly. ${ }^{73}$ These changing perceptions indicate that at a practical

68. Id. § 103(b)(3), 28 U.S.C. § 46(b) (1982).

69. Id.; see, e.g., C.R. Bard, Inc. v. Schwartz, 716 F.2d 874, 219 U.S.P.Q. (BNA) 197 (Fed. Cir. 1983) (court considered it important that decision was by five judge panel).

70. Federal Courts Improvement Act of 1982, $\S 120($ b)(1), 28 U.S.C. $\S 715$ (1982). This provision applies to all the circuits, but in the Federal Circuit at least one key function of the technical advisors is to insure that issued opinions do not conflict with others the court has made. See Rich, Columbia Law School Julius Silver Program in Law, Science and Technology-Inaugural Lecture, 68 J. PAT. \& TRAdemark OfF. Soc'y 604, 617 (1986). The court also circulates all opinions prior to publication; any judge can ask for revisions if she believes the opinion is inconsistent with circuit precedent. Id. As a final check on consistency, the circuit occasionally rehears a case en banc. U.S. Court of Appeals for the Federal Circuit, Internal Operating Procedures § 27(b) (1983).

71. This figure is derived from data presented in Dunner, The Court of Appeals for the Federal Circuit-Its First Three Years: Introduction, 13 Am. INTELlectual Prop. L. Ass'N Q.J. 185, 18788 (1985) (Tables 1-3). The data cover cases decided through October 1985, and my figurc includes only cases dealing with the most common patent issues, that is, novelty and loss of right to patent, 35 U.S.C. $\S 102$ (1982), nonobviousness, id. $\S 103$ (1982), and adequacy of the inventor's disclosurc in his patent, id. $\S 112$ (1982). Where the Federal Circuit vacated a trial court's finding of invalidity, I coimted this as a finding of validity. Like Baum, supra note 65 , I did not include in my calculations appeals from the Patent and Trademark Office. Note, however, that although Baum did not include the Federal Circuit's predecessor, the CCPA, in the list of courts he studied, some decisions of the District of Columbia Circuit included in his figures were probably appeals from decisions made by administrative tribunals in the Patent Office. Note that since the vast majority of Patent Office decisions finding invalidity are upheld by the Federal Circuit $(86 \%)$ the overall invalidity rate for the Federal Circuit jumps to $66 \%$ when these cases are included in the calculation. Dunner, supra, at 187-188. It is also worth noting that for cases decided under $\S 103$, the nonobviousness requirement, the Federal Circuit affirmed $86 \%$ of district court decisions finding patents valid, but only $60 \%$ of district court decisions finding patents invalid. Dunner, supra, at 87, table 1.

72. See Baum, supra note 65 , at 760 (reporting that from 1935 to 1974 , appeals court validity rate was approximately $30 \%$ ).

73. See, e.g., Mangels, Federal Circuit Court is Spurring A Quiet Revolution in the Patent Field, Nat'l L.J., Aug. 24, 1987, at 24, col. 1; Conferences: Protection for High Technology Reviewed at Patent Law Conference, 30 Pat. Trademark \& Copyright J. (BNA) 682, 683 (Oct. 31, 1985) (reporting New York patent attorney's impression that "[t]he CAFC seems to be a plaintiff's court, $\ldots$ in that it tends to adopt a pro-patent position, ... [since] somewhere between 60 to $70 \%$ of all patent claims before the court are held valid, and [in] that infringement is found in anywhere from 80 to $90 \%$ of the cases."); Mintz, The Federal Circuit is Cleaning Up Patentability Standard: The 
level, respect for patents is probably growing.

\section{Substantive Aspects of the Secondary Considerations}

The Federal Circuit has made real changes in patent law doctrine. In particular, the court has begun to reshape the way commercial success and the other secondary factors are used in determining whether an invention is obvious.

\section{a. Commercial Success}

Federal courts consider commercial success the inost important secondary factor. Both in appeals from the Patent Office and in challenges to invalidate patents, commercial success often proves decisive in establishing nonobviousness, especially in conjunction witl other factors. ${ }^{74}$ The court has ruled that success is always admissible as relevant to the question of nonobviousness. ${ }^{75}$

For commercial success to be persuasive, a patentee must do more than show sales or market share data for lier patented product. (Although, under some older cases, this was enough). ${ }^{76}$ Today the patent applicant must show lier product's sales or market share in relation to other products in the market, and demonstrate its comparative success to the court. ${ }^{77}$ Occasionally, the court will examine otlier measures of

Nonobviousness Requirement, L.A. Daily J., July 2, 1985, at 4, col. 3; see also Banner, The Creation of the Federal Circuit Court of Appeals and the Resulting Revitalization of the Patent System, 50 ALB. L. REV. 585, 590 (1986) (secondary factors are essential in the process of strengthening patents). The impression that patents are being given greater protection has also been reported in the business press. See Perry, The Surprising New Power of Patents, ForTune, June 23, 1986, at 57; Schmitt, Business and the Law: Judicial Shift in Patent Cases, N.Y. Times, January 21, 1986, at D2, col. 1 (citing Kodak-Polaroid patent hitigation, which resulted in inassive damage award and injunction for Polaroid, as the "most prominent examplc of an increasingly pro-patent sentiment in American courts").

74. See, e.g., Allen Archery, Inc. v. Browning Mfg., 819 F.2d 1087, 1092, 2 U.S.P.Q.2d (BNA) 1490, 1493 (Fed. Cir. 1987) (commercial success evidence considered in patent challenger's attempt to prove the patentee's invention was obvious); In re Sernaker, 707 F.2d 989, 996-997, 217 U.S.P.Q. (BNA) 1, 78 (Fed. Cir. 1983) (cominercial success must be considered in appeals from the Patent Office); Walker, Objective Evidence of Nonobviousness: The Elusive Nexus Requirement (Part II), 69 J. Pat. \& Trademark OFF. Soc'ycFN 230 (1987) [HeReINafter Walker, Nexus Part II] (discussing both Patent Office appeals and infringement cases).

75. See infra note 136 and accompanying text.

76. See Magnus \& Easterman Co. v. United Can Fastener Corp., 61 F.2d 3, 5, 14 U.S.P.Q. (BNA) 79, 81 (6th Cir. 1932) (patented product comprised $90 \%$ of coinpany's sales, establishing commercial success.)

77. Vandenberg v. Dairy Equip. Co., 740 F.2d 1560, 1567, 224 U.S.P.Q. (BNA) 195, 199 (Fed. Cir. 1984) (raw sales not enough); see also D. DuNNer, J. GAMBrell, M. ADELMAN, R. LIPSEY, \& B. Lewris, Patent Law Perspectives § 2-6[6.-1], at 2-62.7 (2d ed. 1988).

However, the Federal Circuit has affirmed a number of cases where the trial court appeared to consider only raw sales or market share data. See, eg., Windsurfing Int'l, Inc. v. AMF, Inc., 613 F. Supp. 933, 227 U.S.P.Q. (BNA) 927 (S.D.N.Y. 1985), modified on other grounds, 782 F.2d 995, 228 U.S.P.Q. (BNA) 562 (Fed. Cir. 1986); Ralston Purina Co. v. Far-Mar Co, 586 F. Supp. 1176, 1223, 
comparative success, such as whether the invention in question displaced prior inventions or surpassed the sales volume of competing products, ${ }^{78}$ whether the invention led to an increase in the patentee's market share, ${ }^{79}$ or whether it justified an extraordinary unit price. ${ }^{80}$ Of course since many of these factors practically define conimercial success, they do not present much of an additional barrier to the patentee trying to establish patentability.

Once proof of commercial success is conpetently presented, the patentee must demonstrate sonie link between that success and the product's patented features. But the Federal Circuit differs from its predecessors over just how strong that link niust be.

One predecessor, the CCPA, initially demanded proof of a strong link, requiring that it must be "positively clear ... that the commercial success asserted was the direct result of the umique characteristics of the claimed invention. . .."81 The Federal Circuit, following indications in some later CCPA cases, ${ }^{82}$ has softened this requirement considerably by demanding that a patentee show only a "nexus" between the commercial success and the patented invention. ${ }^{83}$ In contrast to the former "direct result" standard, the nexus standard simply requires some connection between the invention and the success. ${ }^{84}$ Although it is difficult to pin

222 U.S.P.Q. (BNA) 863, 900 (D. Kan. 1984), modified on other grounds, 772 F.2d 1570, 227 U.S.P.Q. (BNA) 177 (Fed. Cir. 1985).

78. See, e.g., Vandenberg, 740 F.2d at 1567, 224 U.S.P.Q. (BNA) at 199; Orthopedic Equip. Co. v. All Orthopedic Appliances, Inc., 707 F.2d 1376, 1382, 217 U.S.P.Q. (BNA) 1281, 1285 (Fed. Cir. 1983); Andis Clipper Co. v. Oster Corp., 481 F.Supp. 1360, 1378-79, 206 U.S.P.Q. (BNA) 23, 39 (E.D. Wis. 1979); see also supra note 44 (older Supreme Court cases with similar holdings).

79. Vandenberg, 740 F.2d at 1567, 224 U.S.P.Q at 199; Kansas Jack, Inc. v. Kuhn, 719 F.2d 1144, 1151, 219 U.S.P.Q. (BNA) 857, 861 (Fed. Cir. 1983).

80. Cable Elec. Prods. Inc. v. Genmark, Inc., 770 F.2d 1015, 1026-27 (Fed. Cir. 1985); see also Farmhand, Inc. v. Lahman Mfg. Co., 192 U.S.P.Q. 749, 761 (D.S.D. 1976), aff'd, 568 F.2d 112, 196 U.S.P.Q. (BNA) 597 (8th Cir. 1978).

81. In re Heldt, 433 F.2d 808, 812-13, 167 U.S.P.Q. (BNA) 676, 679 (C.C.P.A. 1970) (emphasis added).

82. See, e.g., Solder Removal Co. v. United States Int'l Trade Comm'n, 582 F.2d 628, 637, 199 U.S.P.Q. (BNA) 129, 137 (C.C.P.A. 1978) (using a nexus test).

83. See, e.g., Windsurfing Int'l Inc. v. AMF, Inc., 782 F.2d 995, 999-1000, 228 U.S.P.Q. (BNA) 562, 564-66 (Fed. Cir.), cert. denied, 106 S. Ct. 3275 (1986); Pentec, Inc. v. Graphic Controls Corp., 776 F.2d 309, 315, 227 U.S.P.Q. (BNA) 766, 769-70 (Fed. Cir. 1985); Vandenberg v. Dairy Euip. Co., 740 F.2d 1560, 1567, 224 U.S.P.Q. (BNA) 195, 199; Simmons Fastener Corp. v. Illinois Tool Works, Inc., 739 F.2d 1573, 1575, 222 U.S.P.Q. (BNA) 744, 774-76 (Fed. Cir. 1984), cert. denied, 471 U.S. 1065 (1985).

84. Compare this to the standard in a 1974 Court of Claims decision, Jacobson Bros. v. United States, 184 U.S.P.Q. (BNA) 181, 187 (Ct. Cl. Trial Div. 1974) ("Since . . . commercial success must be shown to be attributable [to the imvention] . . . it was incumbent on [plaintiff] to show that it was [the patented features of the invention], at least in substantial part, that made his device a success ...") (emphasis added), aff'd 512 F.2d 1065, 185 U.S.P.Q. (BNA) 168 (Ct. C1. 1975). Walker phrases the current Federal Circuit standard as follows: "[T]he proponent of a nexus must show that any extraneous factors do not overshadow the claimed features ..." as causative agents leading to commercial success. Walker, Nexus Part $I$, supra note 41 , at 183 . This captures an important 
down the exact differences between the standards, ${ }^{85}$ it is clear that they lead to different outcomes in some (and perhaps many) cases. ${ }^{86}$

In addition to weakening the standard, the "nexus" test masks underlying inconsistencies in the court's decisions. To take just one example, ${ }^{87}$ consider a pair of recent decisions discussing commercial success as proof of nonobviousness. In Windsurfing Int'l, Inc. v. $A M F$, Inc. ${ }^{88}$ the court upheld a lower court's finding that plaintiff's patented sailboard was nonobvious. The patent challenger introduced substantial evidence that factors other than the sailboard's patented sail booin joint-such as sales of unpatented accessories, extensive advertising, and unpatented features-contributed to the sailboard's cominercial success. ${ }^{89}$ The trial court, relying heavily on evidence of success and other secondary factors, held that the success went "well beyond the effect" " of these nonpatent factors. ${ }^{90}$ The patentee, in other words, had successfully established a nexus.

Yet in another case presenting quite similar facts, Pentec, Inc. v. Graphic Controls Corp., 91 the Federal Circuit upheld a district court's determination that there was no nexus. In Pentec, the inventor of a holding arm for automatic graphic chart pens introduced evidence of substantial commercial success. The patent challenger countered with evidence that the success was attributable to nonpatent features, specifically: (1) the patentee's established market leadership; (2) advertising and proinotion; and (3) other unpatented features of the pen. ${ }^{92}$ In rejecting the patentee's claim that there was a nexus, the court hinted at a much higher standard of proof for a nexus, noting: "[I]t cannot be said that the coinmercial success here inay not have been due in large part to 'other eco-

nuance in the recent cases: While the patentee must rebut alternative causes; the patented features cannot be "overshadowed" unless challenger introduces evidence of these other causes. This comes close to being a presumption that success is a result of the patented features. See infra note 171 and accompanying text.

85. See Walker, Nexus Part I, supra note 41, at 180-83 ("It is difficult to glean anything other than the most amorphous of rules from such a hodgepodge of holdings and such minimal guidance from the Federal Circuit." Id. at 182). But the uncertainty does not preclude Walker from finding that in the wide realm of nonobviousness, "[o]bjective evidence of nonobviousness has become an extremely inportant factor" upon which the practitioner "cannot place too much emphasis ...." Walker, Nexus Part II, supra note 74, at 246.

86. But see In re Heldt, 433 F.2d at 812-13, 167 U.S.P.Q. (BNA) 679 (commercial success evidence not specific enough to overcome obviousness); Pentec, Inc., 776 F.2d at 315-16, 227 U.S.P.Q. at 770-71, (commercial success evidence was specific, but other evidence of preexisting market leadership destroyed the nexus).

87. For other examples, see Walker, Nexus Part I, supra note 41, at 180-83.

88. 782 F.2d 995, 228 U.S.P.Q. (BNA) 562 (Fed. Cir. 1986).

89. Id. at 1000,228 U.S.P.Q. at 565.

90. Id. (citing Windsurfing Int'l, Inc. v. AMF, Inc., 613 F. Supp. 933, 949, 227 U.S.P.Q. (BNA) 927, 939 (S.D.N.Y. 1985)).

91. 776 F.2d 309, 227 U.S.P.Q. (BNA) 766 (Fed. Cir. 1985)

92. Id. at 316,227 U.S.P.Q. at 770. 
nomic and commercial factors unrelated to the technical quality of the patented subject matter." "93 One is left to wonder what standard the Pentec court would require to prove a nexus; the court surely avoided announcing one. Although distinctions can no doubt be drawn between these cases, there is no clear rationale for the divergent decisions, nor has the scant secondary literature suggested one. ${ }^{94}$

Partly as a result of the malleable nexus standard, the court in some cases has used commercial success and other secondary factors to override strong evidence that an invention was obvious. One example is Alco Standard v. Tennessee Valley Authority. ${ }^{95}$ There, the Federal Circuit upheld a patent primarily on the basis of commercial success evidence even though its subject matter-a sensing device for testing structural weaknesses in generator turbine blades-played only a small part in Alco's overall generator testing service. Alco's service procedure included site visits, testing, and interpretation of test data. As Judge Giles Rich pointed out in his dissent, the technical achievement described in Alco's patent consisted of a new way to pick up vibrations in the generator turbine blades. As this was only one small part of the overall package offered by Alco, Judge Rich concluded that Alco had not proved a nexus between the patent and Alco's success in selling its service. ${ }^{96}$ Nevertheless, a majority of the court found the patent valid, relying exphicitly on the commercial success of Alco's service to overcome strong indications of obviousness. ${ }^{97}$

The Federal Circuit has also increased the importance of commercial success as an imdicator of nonobviousness by narrowing the defenses that can be used to offset a showing of success. Prior to the creation of the Federal Circuit, nnany Supreme Court and courts of appeals decisions cited several factors that could offset a patentee's showing of commercial success. These mcluded extensive advertising by the patentee, ${ }^{98}$ superior

93. Id. (quoting Cable Elec. Prods. Inc. v. Genmark, Inc., 770 F.2d 1015, 1027, 226 U.S.P.Q. 881, 888 (Fed. Cir. 1985)).

94. See, e.g., supra note 85. Walker does find certain conclusions may improve a patentee's showing of nexus, proposing a "significant contribution" standard with no overshadowing "extraneous factors." Walker, Nexus Part I, supra note 41, at 183.

95. 808 F.2d 1490, 1 U.S.P.Q.2d (BNA) 1337 (Fed. Cir. 1986).

96. Id. at 1504, 15081 U.S.P.Q.2d at 1350 (Rich, J., dissenting); see also, e.g., Textile Mach. Works v. Louis Hirsch Textile Mach., Inc., 302 U.S. 490 (1938) (success attributable to nonpatented features); American Sterilizer Co. v. Sybron Corp., 614 F.2d 890, 205 U.S.P.Q. (BNA) 97 (3d Cir.), cert. denied, 449 U.S. 825 (1980) (same).

97. Alco, 808 F.2d at 1500-01. 1 U.S.P.Q. at 1344-45. The court also relied on long-felt need in upholding the patent. Id.

98. See, e.g., McClain v. Ortmayer, 141 U.S. 419, 428 (1891) (referring, in opinion invalidating patent in spite of commercial success, to testimony that patentee's increased sales resulted in part because he "made the manufacture of [his product] a specialty, that he made them of superior quality, advertised them in the most extensive and attractive manner, and adopted means of pushing them upon the market, and thereby largely increased the extent of their sales"); see also Lee 
distribution and marketing, ${ }^{99}$ general business acumen, ${ }^{100}$ and evidence that success was a result of unpatented features of the product. ${ }^{101}$ Courts had treated these factors as alternative explanations for the commercial success of a patented product, in effect severing the causal link between the technical merits of the underlying invention and its success in coinmerce.

The Federal Circuit has downplayed two of these factors: advertising and marketing advantages. Although never stating that these factors are insufficient as a matter of law to offset commercial success, the court has found them unconvincing in a number of cases. ${ }^{102}$ The Federal Circuit's disregard of advertising strongly differs from prior cases which had often found extensive advertising budgets a compelling reason to disregard commercial success. ${ }^{103}$

Through substantive changes in the definition of, and defenses to, a showing of commercial success, the Federal Circuit has transforined commercial success fron1 a tiebreaker to a virtual trump card. Moreover, since the Supreme Court rarely grants certiorari in patent cases, these Federal Circuit decisions represent major, and likely long lasting, changes im the importance of commercial success. ${ }^{104}$

Blacksmith, Inc. v. Lindsay Bros., Inc., 605 F.2d 341, 347, 203 U.S.P.Q. (BNA) 211, 212-13 (7th Cir. 1979) (Pell, J. dissenting); Ashland Oil Inc. v. Delta Oil Prods. Corp., 587 F. Supp. 1406, 212 U.S.P.Q. (BNA) 508 (E.D. Wis. 1981) rev'd in part on other grounds, 685 F.2d 175, 216 U.S.P.Q. (BNA) 857 (7th Cir. 1982), cert. denied, 460 U.S. 1081 (1983); Hewes \& Potter, Inc. v. Myerson, 17 U.S.P.Q. (BNA) 418, 420 (2d Cir. 1933).

99. See, e.g., McClain, 141 U.S. at 428 (1891).

100. See, e.g., Paramount Publix Corp. v. American Tri-Ergon Corp., 294 U.S. 464 (1935).

101. See, e.g., Sakraida v. Ag Pro, Inc., 425 U.S. 273 (1976). It is a well-established principle of British patent law that general acceptance of a patented invention does not indicate nonobviousness when it is attributable to features outside the scope of the patent clains. See, e.g., Martin \& Biro Swan v. Millwood, Pat. Cas. 125, 134 [1956] (H.L.). In the Biro case the House of Lords found that the patentee's claims described only the ink dehivery systein for a ball point pen, and not the entire ball point concept, which was already well-known in the penmaking art. The court thus attributed the commercial success of the pen to unpatented features and discarded it as irrelevant. Id. The Federal Circuit has adopted this reasoning in certain cases. See, e.g., Pentec, Inc. v. Graphics Controls Corp., 776 F.2d 309, 227 U.S.P.Q. (BNA) 166 (Fed. Cir. 1985); In re Vamco Machine \& Tool, Inc., 752 F.2d 1564, 1577 n.5, 224 U.S.P.Q. (BNA) 617, 625 n.5 (Fed. Cir. 1985).

102. See, e.g., Hybritech, Inc. v. Monoclonal Antibodies, Inc., 802 F.2d 1367, 1382, 231 U.S.P.Q. (BNA) 81, 91 (Fed. Cir. 1986) (rejecting evidence that success resulted froin extensive advertising); Alco Standard Corp. v. Tennessee Valley Auth., 808 F.2d 1490, 1500-01, 1 U.S.P.Q.2d (BNA) 1337, 1344-45 (Fed. Cir. 1986) (rejecting evidence that success stemmed from marketing advantages). But see Pentec, 776 F.2d at 315-17, 227 U.S.P.Q. at 770-76 (finding no nexus between the adinitted success and the patent features, noting patentee's preexisting market leadership).

103. See cases cited supra note 98. Emphasis on advertising budgets may well have been misguided. Economists, emphasizing that all advertising is not created equal, suggest that the content of the advertising may be as important as its volume. See Benham, The Effect of Advertising on the Price of Eyeglasses, 15 J.L. \& ECON. 337 (1972); Boyer, Informative and Goodwill Advertising. 56 Rev. Econ. \& Statistics 541 (1974). See generally R. Schmalensee, The Economics of ADVERTISING 49 (1972) (concise review of the extensive economic hiterature on advertising).

104. See supra notes $69-70$ and accompanying text (description of Federal Circuit procedures 


\section{b. Other Secondary Factors}

Even before the Federal Circuit was formed, courts relied on a number of objective factors other than commercial success. Although commercial success remains the most important secondary factor in the Federal Circuit's jurisprudence, the others continue to play a supporting role. For the most part, the other factors can be classified as follows: (a) hicensing to other firms; (b) long-felt need for the invention; (c) failure of others to make the invention; and (d) copying of the invention. ${ }^{105}$ The most important secondary factor after commercial success is licensing. Businesses often license their own patented technology for use by other firms, and courts have long treated hicenses as an important secondary consideration in determining whether an invention is obvious. ${ }^{106}$ This is especially true when the likelihood of a strong and valid patent is the only apparent motivation on the part of the licensee to take the license. ${ }^{107}$

A recent Federal Circuit case, In re Sernaker, provides a good exainple of the use of hicensing evidence to prove a patent's validity. ${ }^{108}$ In Sernaker, the patentee had invented a type of embroidered emblem patch and a simplified process for attaching patches to garments. The patentee, citmg extensive commercial success and licensing activity, appealed the Patent Office Board of Appeals' rejection of his application. The Court held in his favor, stating that the Patent Office must consider

for insuring consistency). But cf. Deurson Mfg. Co. v. Panduit Corp., 475 U.S. 809 (1986), vacating 774 F.2d 1082, 227 U.S.P.Q. (BNA) 337 (Fed. Cir. 1985), discussed infra at notes $147-49$ and accompanying text. Since the Federal Circuit reviews its own opinions for consistency, other judges on the circuit may find it difficult to downplay the significance of commercial success in future cases.

105. In some cases, the Federal Circuit has standardized its terminology, thereby eliminating a label for a factor, but not the factor itself. See Walker, Nexus Part II, supra note 74, at 236-40 (reviewing cases on "acquiescence in the industry" subsumed in Federal Circuit cases under "licensing"). However, with respect to at lcast one factor, near-simultaneous invention, the Federal Circuit has failed to adopt prior case law. Decisions im some older cases invoked simultaneous imvention by a number of firms as "objective evidence" that a patented invention was obvious. See 2 D. Chisum, supra note $19, \S 5.05$ [7]. The Federal Circuit has declared that this is no longer to be considered as proof of obviousness. See Environmental Designs, Ltd. v. Union Oil Co., 713 F.2d 693, 698 n.7, 218 U.S.P.Q. 865, 867 n.7 (Fed. Cir. 1983), cert. denied, 464 U.S. 1043 (1984). This position has been criticized-for good reason. See Walker, Nexus Part II, supra note 74, at 243; Note, $A$ Critique of the Use of Secondary Considerations in Applying the Section 103 Nonobviousness Test for Patentability, 28 B.C.L. REv. 357 (1987) (arguing that only those secondary considerations probative of the inventor's state of mind at the tinie of the imvention-namely long-felt need, licensing, and near sinultaneous invention-ought to be relevant to nonobviousness).

106. See, e.g., Coltman v. Colgate-Palmolive-Pcet Co., 104 F.2d 508, 511, 41 U.S.P.Q. (BNA) 380, 383 (7th Cir. 1939); see also John Thropp's Sons Co. v. Seiberling, 264 U.S. 320 (1924); Walker, Nexus Part II, supra note 74, at 236-40. Many commentators characterize this form of evidence as "industry acquiescence," because it is thought to represent a form of deference and respect for the patented technology by those in a position to assess its merits. See 2 D. CH1SuM, supra note 19, $\$ 5.05$ [3], at 5-262 For a critique of sone of the assumptions inherent in this view, see infra notes 257-74 and accompanying text.

107. See Walker, Nexus Part II, supra note 74, at 239.

108. 702 F.2d 989, 217 U.S.P.Q. (BNA) 1 (Fed. Cir. 1983). 
secondary considerations (including licensing) at the time an application is filed, just as a court must consider them in a later suit between a patentee and a challenger. ${ }^{109}$ Among the secondary considerations, the court found licensing especially convincing: "Despite tlie fact that a patent has not yet issued, [the patentee] has been able to license his invention. [His] licensees lave sold millions of the emblems ... [and have] helped revitalize a depressed embroidery industry . . .."110

The Federal Circuit has recognized, however, that many factors other than valid patents can influence a firm's decision to take a license. Where a licensee has other inotivations-especially a desire to avoid litigation, or a need to license a package of technology including the patent at issue-licenses have not been as effective in establishing patentability. ${ }^{111}$ In Stratoflex, Inc. v. Aeroquip Corp., for example, the patentee introduced two licenses into evidence to prove that its pressurized fluid tubing for airplane engines was not obvious. ${ }^{12}$ The court was not convinced. It noted that one license was in settlement of a Patent Office interference proceeding between the patentee and another patent applicant. The other license involved a number of separate patents and a trademark, making it impossible to determine whetlier the patent at issue in the case had substantial value by itself. ${ }^{113}$ In another case, the court recognized that a wide variety of nontechmical considerations often enter into licensing transactions: "[Licensing] programs are not infallible guides to patentability. They soinetimes succeed because they are mutually beneficial to the licensed group ...." 114

In addition to licensing evidence, a patentee can strengthen her case for validity by relying on another secondary factor-a showing that her invention meets a long-felt need. An invention that fills a long-expressed need, the reasoning goes, must not be obvious, or it would liave been invented before. ${ }^{15}$ The long duration of the need demonstrates that

109. Id. at 996-97, 217 U.S.P.Q. at 7-8.

110. Id.

111. See Walker, Nexus Part II, supra note 74.

112. 713 F.2d 1530, 1539218 U.S.P.Q. (BNA) 871, 879 (Fed. Cir. 1983).

113. Id.

114. EWP Corp. v. Reliance Universal, Inc., 755 F.2d 898, 907-08, 225 U.S.P.Q. (BNA) 20, 26 (Fed. Cir.), cert. denied, 106 S. Ct. 131 (1985).

115. See, e.g., Walker, Nexus Part II, supra note 74, at 230-33. Some cases illustrate a basic tension between long-felt need and the presumption, for purposes of 35 U.S.C. $\S 103$, that an inventor las complete knowledge of all relevant prior art in her field. See, e.g., EWP Corp., 755 F.2d at 908, 225 U.S.P.Q. at 20 (Davis, J., concurring) (criticizing majority opimion for not clarifying that relevant, though obscure, prior art describing similar invention obviates the secondary consideration of long-felt need for the patentee's invention). However, in one decision, the Federal Circuit implied that any invention fulfilling a long-felt need would be patentable per se, making it unnecessary for a court carefully to examine prior art. Hodosh v. Block Drug Co., Inc., 786 F.2d 1136, 229 U.S.P.Q. (BNA) 182 (Fed. Cir. 1986), rev'g 226 U.S.P.Q. (BNA) 645 (D.N.J. 1985), cert. 
other inventors had ample time to try to fill it. ${ }^{116}$

An excellent example of the use of long-felt need to prove patentability is W.L. Gore \& Assoc.'s v. Garlock, Inc., ${ }^{117}$ which centered on a patent for the "wonder material" Gore-tex. The unique property of Gore-tex is that it remains waterproof while "breathing," that is, while letting air pass through. Gore-tex is therefore perfect for a wide variety of applications, ranging from outdoor wear to artificial arteries. In the litigation challenging the Gore-tex patent, the inventor introduced evidence on the long-felt need for Gore-tex's coinbination of properties. He showed, among other thimgs, that the U.S. Army had long expressed a desire for a breathable yet waterproof fabric. The Court found this evidence persuasive: "Considering the long-felt need for [such] products and the obvious commercial advantage to be gained by ineeting that need, it is reasonable to conclude tliat the claimed products of . . . [Gore's] patent would not have been obvious . . .."118

Commentators have often noted that long-felt need requires a key inference to effectively prove patentability: the court must infer that the patentee's competitors, faced with the same market pressures, were contemporaneously trying to produce a similar invention. ${ }^{119}$ Introducing another form of secondary factor evidence-the failure of others-eliminates the need for this speculation; it proves directly what is only proved imdirectly with long-felt need. Consequently, courts, including the Federal Circuit, have often rehed on evidence of the failures of others to buttress a holdimg that an invention is not obvious. ${ }^{120}$

A recent Federal Circuit case, Dow Chemical Co. v. American Cyan-

denied, 107 S. Ct. 106 (1986). Judge Rich, writing for the court, reversed a trial court opinion invalidating a patent, stating:

That secondary considerations are not considered unless there is evidence that those in the industry knew of the prior art is a non sequitur. Evidence of secondary considerations is considered independently of what any person knows about the prior art. These considerations are objective criteria ....

Id. at 1144, 229 U.S.P.Q. at 188 (emphasis in original). The trial court had concluded: "Had persons of ordinary skill in the pertinent arts known of these references, the court is persuaded, such long-standing need would have long ago been fulfilled, rendering copying unnecessary and coinmercial success merely continuous." 226 U.S.P.Q. (BNA) at 656 (footnote omitted). The Federal Circuit's decision has been criticized by a leading commentator. 2 D. Chisum, supra note $19, \S 5.05[1]$, at 5-248 n.12.

116. See infra note 248 and accompanying text (classic decisions by Judge Learned Hand on the length of time the need must be felt).

117. 721 F.2d 1540, 220 U.S.P.Q. (BNA) 303 (Fed. Cir. 1983), cert. denied, 469 U.S. 851 (1984).

118. Id. at 1555,220 U.S.P.Q. at 315.

119. See, eg., 2 D. Ch1sum, supra note 19, $§ 5.05[1]$; Walker, Nexus Part II, supra note 74, at 234-36.

120. See, e.g., Dow Chemical Co. v. American Cyanamid Co., 816 F.2d 617, 622, 2 U.S.P.Q.2d (BNA) 1350, 1354-55 (Fed. Cir. 1987), cert. denied, 108 S. Ct. 149 (1987); Panduit Corp. v. Dennison Mfg. Co., 774 F.2d 1082, 1099, 227 U.S.P.Q. 337, 348-49 (Fed. Cir. 1985), vacated on other grounds, 106 S. Ct. 1578 (1986). 
amid Co., ${ }^{121}$ illustrates how courts weigh the failure of other firms in analyzing patentability. At issue was the validity of Dow's patent on a process for converting acrylontrile, an inexpensive source inaterial, into acrylamide, a coinpound that forms the foundation for commercially inportant polymers. Among the objective evidence Dow introduced to prove that its process was not obvious were the unsuccessful atteinpts of other firms-including American Cyanamid-to perfect the process despite investing considerable sums in research and developinent directed towards this end. "Cyanamid," the Court concluded, "tried but failed to develop the claimed invention and copied it instead." 122 As this conclusion shows, the failed efforts of a skilled coinpetitor often demonstrate the nonobviousness of an invention better than any other objective evidence. ${ }^{123}$

Fimally, evidence that other firms copied the patentee's invention, especially when accoinpanied by evidence that those firms tried and failed to inake the imvention on their own, can usually-though not always-contribute significantly to a showing of nonobviousness. ${ }^{124}$ The court, however, is not always persuaded by evidence of copying. In Vandenberg v. Dairy Equipment Co. the patentee submitted uncontroverted proof of direct copying by the patent challenger, whose product "differ[ed] from [the patentee's] system only in a few insignificant particulars."125 Nevertheless, partly based on evidence froin the patent challenger that its employees had independently developed a similar design, ${ }^{126}$ the court gave short shrift to the patentee's copying evidence and invalidated the patent. This stands in stark contrast to the court's oft-repeated maxim that "copying a [patented] invention, rather than one

121. 816 F.2d 617, 2 U.S.P.Q.2d (BNA) 1350 (Fed. Cir. 1987).

122. Id. at 622, 2 U.S.P.Q.2d at 1355; see also Hercules, Inc. v. Exxon Corp., 497 F. Supp. 661, 680, 207 U.S.P.Q. (BNA) 1088, 1104 (D. Del. 1980) ("[One company's] researchers worked for more than four years before realizing the suitability of bridge-ringed hydrocarbons [the patented technique at issue] .... That so many companies conducted parallel research without making the same discovery further demonstrates the unobviousness of the invention.").

123. See infra notes $242-56$ and accompanying text.

124. See, e.g., Dow Chemical Co., 816 F.2d at 6222 U.S.P.Q. at 1355; Cable Elec. Prods., Inc. v. Genmark, Inc., 770 F.2d 1015, 1026-27, 226 U.S.P.Q. (BNA) 881, 888 (Fed. Cir. 1984); Vandenberg v. Dairy Equip. Co., 740 F.2d 1560, 1567, 224 U.S.P.Q. (BNA) 195, 199 (Fed. Cir. 1984). Dictum in one case suggests that more firms than just the patent challenger must copy the patentee's invention Pentec, Inc. v. Graphic Controls Corp., 776 F.2d 309, 317, 227 U.S.P.Q. (BNA) 766, 771 (Fed. Cir. 1985); see also Cable Elec. Prods, Ine, 770 F.2d at 1028, 226 U.S.P.Q. at 889 (more than the mere fact of copying by an accused infringer is needed to affect a deterinination on the obviousness issue). Other cases, however, have upheld patents on evidence of copying by the challenger alone. See, e.g., Dow Chemical Co., 816 F.2d 617.

125. 740 F.2d 1560, 1564, 224 U.S.P.Q. (BNA) 195, 197 (Fed. Cir. 1984).

126. Id. at 1567, 224 U.S.P.Q. at 199 (evidence consisted of testimony by the challenger's employees that they had drawn up a preliminary sketch of a similar design that only incorporated the dimensions of the patentee's device). 
within the public doinain, is indicative of nonobviousness." 127 Such an inconsistent position exacerbates the conflict between discouraging infringement of valid patents and encouraging challenges to questionable patents-an important policy tension running throughout patent law. ${ }^{128}$

\section{Secondary Factors: Evidentiary and Procedural Aspects}

The shift in the Federal Circuit's evidentiary and procedural treatment of the secondary factors provides perhaps the inost telling measure of the growing influence of these factors. The Federal Circuit has expanded the law to accommodate secondary factors in three main areas: (1) burden of proof; (2) relevance versus weight of the secondary factors; and (3) standard of review of lower court decisions.

\section{a. Burden of Proof}

Patent disputes arise in two contexts-patent appeals and patent challenges-each of which carries with it a slightly different burden of proof. Where a patent examiner rejects an application as obvious, the patentee can appeal the decision to an adininistrative tribunal within the Patent Office. ${ }^{129}$ The Office has the burden of establishing a prima facie case that the invention was obvious. Once inet, the burden shifts to the patentee. ${ }^{130}$ The shifting of the burden is justified by the presumption that the patentee possesses the facts pertaining to the secondary considerations. ${ }^{131}$ Under a similar rationale, where a private party in court challenges a patent, the burden remains with the patentee throughout the trial. ${ }^{132}$ In both proceedimgs, the patentee is required to establish soine connection between secondary consideration evidence and the patented features of her product or process. ${ }^{133}$ This is the function of the nexus

127. Windsurfing Int'l, Inc. v. AMF, Inc., 782 F.2d 995-1000, 228 U.S.P.Q. (BNA) 562, 565 (Fed. Cir. 1986), cert. denied, 106 S. Ct. 3275 (1986).

128. See, e.g., Lear, Inc. v. Adkins, 395 U.S. 653, 162 U.S.P.Q. (BNA) 1 (1969) (refusing to enforce license agreement provision prohibiting licensee from challenging the validity of the licensed patent, on the grounds that the law should encourage challenges to patents). See genterally MALCHUP, ECONOMIC REVIEW, supra note 2, at 26-29 (describing basic policy tensions in patent law). Cf. R. Nelson, Institutions Supporting Technical Change in Industry 6 (Nov. 1986) (unpublished manuscript on file with the California Law Review) (discussing both the economic necessity for means to insure that $R \& D$ investment can be recouped via legal protection and the importance of imitation and dissemination of R\&D-related information throughout industry-what the author calls the "public vs. private faces of technology").

129. See, e.g., In re Old, 229 U.S.P.Q. (BNA) 196 (Pat. \& Trademark Off. Bd. of Pat. App. \& Interferences 1985). An interference is a proceeding among two or more patent applicants to determine who made a particular invention first.

130. Id. at $199-200$.

131. See Walker, Nexus Part $I$, supra note 41 , at 178-80.

132. Atlas Powder Co. v. E.I. Du Pont de Nemours \& Co., 750 F.2d 1569, 1573, 224 U.S.P.Q. (BNA) 409, 411 (Fed. Cir. 1984).

133. Id. On the other hand, once the patentee has made out a prima facie case establishing a nexus-generally by proving that the item disclosed and claimed in the patent has achieved 
requirement described in our earlier discussion. One slould bear in mind one key point from tliat discussion: Although the patentee has the burden of proving secondary factors, slie will often easily establish the minimal causal link of the nexus requirement, making these factors potent additions to her case for nonobviousness. Whether they will be decisive additions is difficult to predict. We have seen $\mathrm{m}$ our discussion of the Windsurfing and Pentec cases tliat the Federal Circuit's nexus standard is hardly a model of clarity. ${ }^{134}$

\section{b. Weight versus Relevance}

Not only has the Federal Circuit created an uncertain nexus standard, it lias addressed another evidentiary question bearing on the secondary factors: Whether the cliallenger's counter-evidence undercuts the relevance of the secondary consideration, and hence its admissibility, or whether it merely detracts from the weight of that consideration. The Graham case left this question unanswered for nearly twenty years.

Prior to the Federal Circuit's creation, courts had held that proof of a causal link between secondary factors and patented features was a precondition to admission of secondary factors. ${ }^{135}$ The Federal Circuit clarified the relevancy issue in Stratoflex, Inc. y. Aeroquip Corp. when it said: "It is jurisprudentially inappropriate to disregard any relevant evidence .... Thus evidence arising out of the so-called 'secondary considerations' must always when present be considered en route to a determination of obviousness."136 After the Stratoflex case, the only open issue is how much weight a court should give the evidence of secondary considerations.

The Federal Circuit has stated that commercial success, and indeed all the secondary factors "may be the most pertinent, probative, and revealing evidence available," and that they "should when present always be considered an integral part of the analysis." 137 The court has also

success-the burden shifts to the challenger to rebut this prima facie case. Demaco Corp. v. F. von Langsdorff Licensing, Ltd., 7 U.S.P.Q.2d (BNA) 1222, 1226 (Fed. Cir. 1988); Diversitech Corp. v. Century Steps, Inc., 7 U.S.P.Q.2d (BNA) 1315, 1318 (Fed. Cir. 1988); cf. Emery, Patent Law: Obviousness, Secondary Considerations, and the Nexus Requirement, 1986 ANN. REV. AM. L. 117, 140 (expressing support for rule requiring patent challenger to carry the burden of proof in disproving the existence of a nexus).

134. See supra notes 87-94.

135. See, e.g., In re Felton, 484 F.2d 495, 500-01, 179 U.S.P.Q. (BNA) 295, 299 (C.C.P.A. 1973) (secondary considerations admissible because affidavits from industry professionals on advantages of the design established nexus between invention and success); In re Caveney, 386 F.2d 917, 923, 155 U.S.P.Q. (BNA) 681, 686-87 (C.C.P.A. 1967) (evidence of commercial success can be admitted only after establishing a nexus between it and the invention under review).

136. 713 F.2d 1530, 1538, 218 U.S.P.Q. (BNA) 871, 879 (Fed. Cir. 1983). See Davis, Patents and Commerical Success in the U.S. Federal Circuit, 3 INTELL. Prop. L.J. 291, 303 (1988) (praising this position).

137. W.L. Gore \& Assoc., Inc. v. Garlock, Inc., 721 F.2d 1540, 1555, 220 U.S.P.Q. (BNA) 303, 
stated, "That evidence is 'secondary' in time does not mean that it is secondary in importance."138 Several Federal Circuit judges have waged a prolonged cainpaign to discredit the "secondary" label that the Supreine Court assigned to these factors in Graham. These judges, including Federal Circuit Chief Judge Harold Markey, contend that the term "secondary" is at least "unfortunate," if not coinpletely ineaningless. ${ }^{139}$ More importantly, the Court has begun to refer to the secondary factors as one of "the four inquiries mandated by Graham."140 There is simply no doubt that the Federal Circuit, through subtle changes in the standard for introducing these factors and in weighing these factors once introduced, has elevated them, when present, to a central place in the law of patentability. ${ }^{141}$

314 (Fed. Cir. 1983), cert denied, 469 U.S. 851 (1984); see also Custom Accessories, Inc. v. JeffreyAllan Indus., 807 F.2d 955, 960, 1 U.S.P.Q.2d (BNA) 1196, 1199 (Fed. Cir. 1986) (same, but cautioning that absence of objective evidence of secondary factors is not fatal to patentability). The Federal Circuit has left no doubt that it believes this evidence to be relevant. Where a patentee's competitors are alleged to be selling products that are copies of the patentee's product, the patentee is allowed to use competitors' sales data as proof of commercial success. This applies even to competitors who are not parties to an infringement action. Truswal Systems Corp. v. Hydro-Air Eng'g, Inc., 813 F.2d 1207, 2 U.S.P.Q.2d 1034 (Fed. Cir. 1987) (holding that sales data of nonparty is relevant evidence and therefore may be the subject of a discovery order or subpoena). But see American Standard, Inc. v. Pfizer, Inc., 828 F.2d 734, 3 U.S.P.Q.2d (BNA) 1817 (Fed. Cir. 1987) (ruling sales data of nonparty not discoverable in the case at bar) (criticized in a partial dissent by Judge Pauline Newman, stating that "this court reached a different conclusion on similar facts in Truswal ...") Id. at 747, 3 U.S.P.Q.2d at 1826 (Newınan, J., dissenting).

138. Truswal, 813 F.2d at 1212, 2 U.S.P.Q.2d at 1038.

139. See Markey, Why Not the Statute?, 65 J. PAT. OFF. Soc'Y 331, 338-39 (1983) ("the misnamed 'secondary considerations' "); see also Federico, Further Comments and Observations on the Origin of Section 103, in WITHERSPOON, NONOBV1OUSNESS, supra note 19, at 1:301-1:305, 1:305 ("[T]he use of the word 'secondary' with respect to considerations which may enter into the determination seeins unfortunate."); Rich, Laying the Ghost of the "Invention" Requirement, 1 AM. PAT. L.A.Q.J. 26, 38 (1972) ("There is just one unfortunate word in [Graham's secondary factors] passage: 'secondary.' I don't think it should be given any weight thougl sone courts seem to have done so ...."). But see Edwards, That Clumsy Word "Nonobviousness"!, 60 J. PAT. OfF. Soc'Y 3, 11 (1978) ("I do not agrec [with Judge Rich] that Federal Courts have the right to ignore or overrule .... [I]t clearly is the Supreme Court of the United States which is final authority on interpretation of both federal statutory and Constitutional law"). One coinmentator has inade an attempt to reconcile these two views. Chisum, Address before the AIPLA Annual Meeting, AM. INTELL. Prop. L. Assoc. BULL. 618, 620-21 (1984) ("[The] considerations are secondary not because they are secondary in importance [but] because they are relevant through a process of inference to the ultinate technical issue of nonobviousness [and being] relevant through a chain of inference, their force may be weakened for a variety of reasons."); see also Truswal Systems Corp. v. Hydro-Air Eng'g, Inc., 813 F.2d 1207, 2 U.S.P.Q.2d 1034, 1038 (Fed. Cir. 1987).

140. Bansch \& Loinb, Inc. v. Barnes-Hind/Hydrocurve, Ine., 796 F.2d 443, 446, 230 U.S.P.Q. (BNA) 416, 418 (Fed. Cir. 1986) (emphasis added), cert. denied, 108 S. Ct. 85 (1987); see also supra note 57. Commentators have begun to pick up this theme. See Emery, supra note 133, at 141 (referring to the Federal Circuit's superior test for nonobviousness, a "one-step, four-part obviousness test").

141. Truswal, 513 F.2d at 1212, 2 U.S.P.Q.2d at 1038. 


\section{c. Standard of Review}

Theoretically, the Federal Circuit, like other federal appellate courts, may overrule only legal conclusions and "clearly erroneous" findings of fact. While this degree of power would seem to limit the court's ability to disturb findings of fact related to commercial success, the Federal Circuit has in fact practiced a double standard where findings of commercial success are concerned. ${ }^{142}$ In its pubhished opinions so far, the court has apparently never questioned a lower court's finding of commercial success, nor has it ever appeared to question a finding that such success is attributable to the patented features of the invention. ${ }^{143}$ In fact, the Federal Circuit has affirmed lower court opinions that lackcd evidence linking commercial success to the patented invention. ${ }^{144}$

On the other hand, where a trial court has refused to find commercial success, or found it attributable to causes other than the patented features of the invention, the Federal Circuit has carefully examined the evidence adduccd at trial. On a number of occasions the Federal Circuit

142. The following remarks by one of the court's senior members, Judge Giles Rich, sheds soine light on the way one Federal Circuit judge views trial findings:

One of the things that changed in the transition from CCPA to CAFC [the Federal

Circuit] is much greater emphasis in the new court on standard of review .... In the CCPA, we were not reviewing trials, and Rule 52(a) was not applicable. Or if it was, we ignored it. Reviewing the PTO Boards [Patent and Trademark Office Boards of Patent Appeals], our attitude was we reversed them if they were wrong.... I also inust say that I have great difficulty in the distinction between an alleged fact being wrong and being "clearly erroneous," and I seem to remember a learned colleague saying "It doesn't matter, if you want to upset the fact finding, you just have to use the magic words."

Rich, Thirty Years of This Judging Business, 14 AM. INTELL. Prop. L.A.Q.J. 139, $148-49$ (1986); cf. Note, A Proposal to View Patent Claim Nonobviousness from the Policy Perspective of Federal Rule of Civil Procedure 52(A), 20 Mich. J.L. REF. 1157 (1987) (concluding that appellate court workload reduction policy of Rule 52(a) is undercut by Federal Circuit's rule that nonobviousness finding is reviewable as a legal eonclusion of the trial court).

143. See, e.g., Windsurfing International, Inc. v. AMF, Inc., 782 F.2d 995, 999, 228 U.S.P.Q. (BNA) 562, 565 (Fed. Cir. 1986) (finding that trial court did not inpermissibly credit evidence of coinmercial success); King Instrument Corp. v. Otari Corp., 767 F.2d 853, 859 n.3, 226 U.S.P.Q. (BNA) 402, 406 n.3 (Fed. Cir. 1985) ("While there was no specific finding of nexus between the evidence of commercial success and the claimed invention we inay properly assume that this evidence entered into the district court's consideration under the correct standard." (citation omitted)); Bio-Rad Laboratories, Inc. v. Nicolet Instrunnent Corp., 739 F.2d 604, 641, 222 U.S.P.Q. (BNA) 654, 660 (Fed. Cir.) (presuming, based on evidence presented, that jury found nexus), cert. denied, 469 U.S. 1038 (1984).

144. See, e.g., Simmous Fastener Corp. v. Illinois Tool Works, Inc., 739 F.2d 1573, 1574-75, 222 U.S.P.Q. (BNA) 744, 746 (Fed. Cir. 1984), rev'g 560 F. Supp. 1277, 218 U.S.P.Q. (BNA) 547 (N.D.N.Y. 1983), cert. denied, 471 U.S. 1065 (1985). In Simmons, the trial court had invalidated a patent on a screw anchor used to attach screws inside refrigerators. The trial court had found the patented invention obvious on its face and scarcely considered secondary consideration evidence. 560 F. Supp. at 1292, 218 U.S.P.Q. at 560 . The Federal Circuit reversed and remanded with the admonition that the secondary considerations are always relevant. Nevertheless, the court noted that certain statenents by the trial court amounted to a finding that the required nexus was present. 739 F.2d at 1575, 222 U.S.P.Q. at 746 . Thus, the Federal Circuit determined that a trial court which did not even admit secondary consideration evidence had found a nexus. 
has reversed trial courts that completely ignored commercial success. ${ }^{145}$ Although the Federal Circuit does not always reverse decisions invalidating patents on successful inventions, ${ }^{146}$ it appears to scrutinize more closely decisions rejecting evidence of success than those accepting it. This parallels its mcreased willingness to overturn trial court decisions invalidating patents.

The Federal Circuit's intense scrutiny of lower courts' findings of commercial success led to the only occasion so far when the Supreme Court has vacated one of the Federal Circuit's opimions. In Dennison Mfg. Co. v. Panduit Corp. ${ }^{147}$ the Federal Circuit reversed a trial court decision invalidating a patent for obviousness. The Supreme Court vacated and remanded the Federal Circuit opinion, stating that it was unclear whether the trial court's findings had been deeined clearly erroneous or whether the Federal Circuit had reversed the trial court as a matter of law. ${ }^{148}$ On remand, the Federal Circuit reinstated its decision $\mathrm{m}$ an opinion emphasizing that obviousness was a question of law, although necessarily based on certain findings of fact. ${ }^{149}$ Allowing the appellate court to consider facts in this manner apparently preserves the authority of the Federal Circuit without overtly undercutting the tradi-

145. See, e.g., Uniroyal, Inc. v. Rudkin-Wiley Corp., 837 F.2d 1044, 1053-54, 5 U.S.P.Q.2d (BNA) 1434, 1440 (Fed. Cir. 1988) (reversing trial court's invalidation of patent on truck air deflector; rejecting trial court's conclusion that success of device was due to energy crisis, not to nexus with invention) rev'g in part, aff'g in part, vacating in part, and remanding sub.nom. Saunders v. Air-Flo Co., 435 F. Supp. 298, 196 U.S.P.Q. (BNA) 168 (N.D. Ind. 1977); Hybritech, Inc. v. Monoclonal Antibodies, Inc., 802 F.2d 1367, 231 U.S.P.Q. (BNA) 81 (Fed. Cir. 1986), rev'g. 623 F. Supp. 1344, 227 U.S.P.Q. (BNA) 215 (N.D. Cal. 1985); Simmons Fastener Corp. v. Illinois Tool Works, Inc., 739 F.2d 1573, 222 U.S.P.Q. (BNA) 744 (Fed. Cir. 1984), rev'g, 560 F. Supp. 1277, 218 U.S.P.Q. (BNA) 547 (N.D.N.Y., 1983), cert. denied, 471 U.S. 1665 (1985) (see supra note 144).

146. See In re Vamco Machme \& Tool, Inc., 752 F.2d 1564, $1577 \&$ n.5, 224 U.S.P.Q. (BNA) 617, 625 \& n.5 (Fed. Cir. 1985); Litton Systems, Inc. v.Whirlpool Corp., 728 F.2d 1423, 1440-42, 221 U.S.P.Q. (BNA) 97, 107-09 (Fed. Cir. 1984) (same re: design patent); Aktiebolaget Karlstads Mekaniska Werkstad v. United States Int'1 Trade Comm'n, 705 F.2d 1565, 217 U.S.P.Q. (BNA) 865, 870-73 (Fed. Cir. 1983). In fact, the Federal Circuit has close to a perfectly "even" record of affirming and reversing trial courts-a fact of which the court is well aware. See Markey, Second Annual Federal Circuit Judicial Conference: State of the Court, 104 F.R.D. 210, 211 (1985) (presentation by Chief Judge Markey citing an unnamed study published that year, probably Dunner, Introduction to Articles in Symposium of the First Three Years of The United States Court of Appeals of the Federal Circuit, 13 AM. INTELL. Prop. L.A.Q.J. 185, 187 Table I (1985)); supra note 71. Of course, the reversal rate is not nearly as inportant as which cases are reversed, nor even as important as what general signals are sent to trial courts, patentees, and other inventors. If potential patent challengers shy away from bringing declaratory actions or performing research in fields where commercially successful inventions are prevalent, the impact of the doctrinal shift in the Federal Circuit will be felt just as strongly as if the court held in favor of the patentee in most cases. In this sense it is the untried cases that may be most significant.

147. 475 U.S. 809 (1986), vacating 774 F.2d 1082, 227 U.S.P.Q. (BNA) 337 (Fed. Cir. 1985).

148. Id. at 811 . If the Federal Circuit's reasoning reached neither of these levels, the decision would be in error.

149. 810 F.2d 1561, 1566, 1 U.S.P.Q.2d (BNA) 1593, 1595-96 (Fed. Cir. 1987). For a critique of this reasoning, see Note, supra note 142 . 
tional importance of the factinder in patent cases. This approach to the question predates the Federal Circuit, however. ${ }^{150}$

Since juries generally favor patentees, ${ }^{151}$ appeals of jury decisions present a special case. In these cases, the Federal Circuit has shown little desire to change the law. In keeping with older cases, ${ }^{152}$ the Federal Circuit has held that special interrogatories are required to plumb the basis of jury decisions concerning obviousness. ${ }^{153}$ Likewise, the court continues the established practice of reviewing jury instructions to make sure they conform to current doctrine regarding secondary factors and the nexus requirement. ${ }^{154}$

In sum, the Federal Circuit has thoroughly transformed commercial success, indeed for that inatter all secondary factors, froin minor to major components in the nonobviousness determination. Building on the ainbiguous Supreme Court case law, the Federal Circuit has enhanced the substantive importance of these factors, while at the same time reducing evidentiary and procedural obstacles to their use. Whether this transformation has been based on solmd principles, and whether the court has carried it out in the most reasonable fashion, are discussed in Section III.

III

\section{ANALYTICAL AND ECONOMIC APPROACHES TO THE SECONDARY CONSIDERATIONS}

The Federal Circuit's decisions on commercial success send a strong and clear message to the lower courts: The patent systein seeks to reward innovation, so take seriously all indications of commercial success. The message rings with the echoes of the court's founding princi-

150. See, e.g., Tights, Inc. v. Acme-McCrary Corp., 541 F.2d 1047, 1060, 191 U.S.P.Q. (BNA) 305, 313 (4th Cir. ), cert. denied, 429 U.S. 980 (1976); see also Comment, Nonobviousness in Patent Law: A Question of Law or Fact, 18 WM. \& MARY L. REv. 612 (1977) (arguing that nonobviousness should be a question of pure fact). The Federal Circuit's law and fact analysis has been justified on the grounds that it allows quick resolution of patent validity without necessitating that cases be remanded to the trial court; Note, Panduit Corp. v. Denison Manufacturing Co.: De Novo Review and the Federal Circuit's Application of the Clearly Erroneous Standard, 36 AM. U.L. REv. 963 (1987). Additionally, some commentators have pointed out that the court is more expert in patent law than trial courts, and thus should be permitted to resolve "mixed" questions of law and fact in order to fulfill its statutory mandate of stabilizing patent law. R. Dreyfuss, The Federal Circuit: A Case Study in Specialized Courts 55 (February 10, 1988) (unpublished article on file with the California Law Review).

151. See Baldo, Juries Love the Patent Holder, ForBES, June 17, 1985, at 147.

152. See Walker, Nexus Part I, supra note 41, at 186.

153. See, e.g., Structural Rubber Prods. Co. v. Park Rubber Co., 749 F.2d 707, 720, 223 U.S.P.Q. (BNA) 1264, 1274, (Fed. Cir. 1984); Perkin-Elıner Corp. v. Computervision Corp., 732 F.2d 888, 893, 221 U.S.P.Q. (BNA) 669, 673 (Fed. Cir.), cert denied, 469 U.S. 857 (1984).

154. Walker, Nexus Part I, supra note 41, at 186-87. 
ple-to make patent doctrines more predictable and thereby foster technological innovation.

On its surface then, commercial success is a valuable factor on which to base patent decisions: First, it is "objective" evidence, which forins the foundation of a predictable doctrine; second, it ensures that a patent will issue when the very thing the patent system seeks to encourage-innovation-has taken place. Nonetheless, commercial success inay be an inappropriate factor in patent decisions, because it relies upon indirect evidence, and because it assumes a simphistic conceptual model of innovation.

\section{A. Commercial Success and the Long Inferential Trail}

Commercial success is a poor indicator of patentabihty because it is indirect; it depends for its effectiveness on a long chain of inferences, and the links in the chain are often subject to doubt. This was one of the central imsights of a seminal article on patentability written in 1966 by Edmund Kitch. ${ }^{155}$ Kitch argued that commercial success was an unreli-

155. Kitch, supra note 24 at 330-35 (critiquing the reasoning of Note, Subtests of "Nonobviousness": A Nontechnical Approach to Patent Validity, 112 U. PA. L. REV. 1169 (1964) (cited in Graham v. John Deere Co., 383 U.S. 1, 18 (1966)), on the relevance of circumstantial evidence of patentability). Even after more than twenty years, this is still the most thoughtful and comprehensive statement of the role of the secondary considerations. For other articles on the probative value of the secondary factors, mostly aimed at patent practitioners, see Bender, Griffen \& Lipsey, Patent Decisions of the United States Court of Appeals for the Federal Circuit: The Year 1985 in Review, 35 AM. U.L. REv. 995, 1008-09 (1986) (emphasizing the Federal Circuit's heavy weighing of secondary considerations and its caution in appraising their nexus to the merits of invention); Hartung, "Prior Art": The Undefined Key to Section 103 of the 1952 Patent Act, 32 DRAKE L. REV. 703 (1982-1983) (advocating clearer definition of "prior art"); McClung \& Bliss, So-Called "Secondary Considerations" Related to the Nonobviousness of an Invention, 26 1DEA 95 (1985) (reviewing various perspectives regarding the relative importance of secondary factors); Mintz \& Racine, Anticipation and Obviousness in the Federal Circuit, 13 AM. INTELL. Prop. L.A.Q.J. 195, 217 (1985) ("the relevance of so-called 'secondary considerations' . . . has been emphatically endorsed by the Federal Circuit"); Walker, Nexus Part I, supra note 41, at 188 (discouraging use of bald evidence of coinmercial success and other indicia in nexus analysis); Walker, Nexus Part $I$, supra note 74, at 247 (same for other secondary indicia, such as long-felt need and failure of others); Note, A Critique of the Use of Secondary Considerations in Applying the Section 103 Nonobviousness Test for Patentability, 28 B.C.L. REv. 359 (1987) (arguing for linitation of secondary considerations to those which are probative of the state of mind of a person having ordinary skill in the art); Note, Patent Law: Doctrinal Stability-A Research and Development Definition of Invention is Key, 20 VAL. U.L. REV. 653 (1986) (criticizing the definition of invention as gleaned from $\S 103$ of the Patent Act). For a sampling of pre-Federal Circuit articles and notes, see Boyer, Commercial Success as Evidence of Patentability, 37 FORDHAM L. REV. 573 (1969) (reviewing divergcnt approaches to success and extolling its value as index of invention); Note, The Standard of Patentability-Judicial Interpretation of Section 103 of the Patent Act, 63 CoLUM. L. REV. 306 (1963) (suggesting adoption of objective "indicia of invention" to stabilize the law); Comment, $A R e$ examination of the Problem of Nonobviousness and Patent Validity, 4 GoNz. L. REV. 65 (1968) (advocating elevation of secondary considerations to status of primary indicia); Note, Subtests of "Nonobviousness": A Nontechnical Approach to Patent Validity, 112 U. PA. L. REV. 1169 (1964) (arguing for consideration of nontechnical indicia of nonobviousness). 
able indicator of nonobviousness. To illustrate his point, Kitch identified four inferences a judge must make to work backward from evidence of market success to a conclusion of patentable invention:

First, that the commercial success is due to the innovation. Second, that ... potential commercial success was perceived before its development. Third, the potential commercial success having been perceived, it is likely that efforts were made [by a number of firms] to develop the improvement. Fourth, the efforts having been made by men of skill in the art, they failed because the patentee was the first to reduce his development to practice. ${ }^{156}$

With only the fact that one company has successfully innovated as a starting point, a court is asked to reconstruct a long series of events and, more importantly, to decide how much of the final success is attributable to each factor introduced along the way. Each inference is weak, because there are almost always several explanations why a product was successful or why other firms missed a market opportunity. ${ }^{157}$ Only the last piece of the puzzle - the failure of others independently to produce this innovation-is indisputably established. This "objective evidence" requires an extraordinary job of factual reconstruction.

Despite the cogency of this attack, Kitch lias simce clianged his position in a later article where lie describes a new theoretical explanation for the workings of the patent system. ${ }^{158}$ In this second article, Kitch argues that the patent systein operates much like the mineral riglits claiming system used in public lands in the western Umited States during the latter part of the nineteenth century. ${ }^{159}$ A patent, according to this "prospect theory," is like a mining claim. It gives its liolder the riglit to control the future development of a property-which in the case of patents is a useful idea. It is within this broad reappraisal of the patent system that Kitch shifted his position on commercial success. He uses the prospect function to explain a number of patent law's more puzzling features, including the use of commercial success:

The fact that a product or process within the terms of the patent claim is commercially successful tells the court that the patent serves as the foundation for a series of now valuable contract rights. By announcing that the subsequent value of those rights will be taken into account if the patent leads to a successful product, the court increases the security of the investment process necessary to maximize the value of the patent. ${ }^{160}$

The prospect theory is a significant contribution to the theoretical

156. Kitch, supra note 24, at 332 .

157. Id.

158. Kitch, The Nature and Function of the Patent System, 20 J.L. \& EcoN. 265, 283 (1977).

159. Id. at 266 .

160. Id. at 283 . 
literature on patents ${ }^{161}$ because it goes beyond the orthodox view of patents as a reward for the completion of a specific invention. ${ }^{162}$ It recognizes that most patents come at the beginning of a long process leading from conception to innovation. By emphasizing the creation of property riglits in the future development path of the invention, that is, in the myriad potential apphications of the invention claimed in the patent, the prospect theory fundamentally shifted the temporal focus of patent theory from ex post analysis to consideration of the ex ante effects of patents as incentives to invent and mnovate. Rather than characterizing a patent as a reward for completing a project, Kitch sees it as an incentive to complete the project, secure in the knowledge that the property rights granted by the patent make one safe from theft of, and encroachment on, the project's central ideas.

Despite its appeal, the prospect theory has had its share of critics. The criticisms center on the fact that the law grants only limited rights to future applications of the imvention claimed im a patent. ${ }^{163}$ The scope of patent protection depends primarily on the precise language of the patent claim or claims, which is usually limited by both prior related patents and prior unpatented technology. ${ }^{164}$ Consequently, far from holding exclusive rights over the future development of his invention, a patentee is sometimes forced to take a license from another inventor who has improved on the patentee's own imvention-a case of so-called "blocking patents." 165 These limitations to the scope of patents, as well as empirical evidence on the very limited economic benefits that fiow from the

161. See DeBrock, Market Structure, Innovation and Optimal Patent Life, 28 J.L. \& ECON. 223, 225-26 (1985).

162. This function had been emphasized by some of the older accounts of the workings of the patent system. See, e.g., MACHLUP, EcoNOMIC REVIEW, supra note 2, at 23 (reviewing views of nineteenth century European economists who envisioned patents as a "reward by monopoly").

163. See, e.g., F.M. SCHERER, supra note 16; Beck, The Prospect Theory of the Patent System and Unproductive Competition, 5 RES. L. \& ECON. 193 (1983) (patent law does not protect all or even many future developments of a technology).

164. See, e.g., Noonan, Understanding Patent Scope, OR. L. REV. 717, 723-25 (1986). The Patent Office narrows a patentee's claims in a give-and-take procedure. The impact of such "claims limitations" on subsequent infringement suits is that an aceused infringer can escape liability by proving that her invention is within a category of technology that the patentee "disclaimed." Such a disclaimer usually comes in response to an objection by the Patent Office that the patent claim is too broad-that is, that it would encompass technology in the prior art, or that it claims more than the patent apphicant has really invented. Id. at 724.

165. See, e.g., Marcom Wireless Tel. Co. v. DeForest Radio Tel. \& Tel. Co., 236 F. 942 (S.D.N.Y. 1916), aff'd, 243 F. 560 (2d Cir. 1917) (patent on evacuated container having two electrodes (the diode) was infringed by improvement patent on triode; since latter necessarily contained two diodes, triode patentee required to take license from diode patentee to use diode invention, and diode patentee required to take hicense to use the improvement); 1 P. RosENBERG, Patent LAw Fundamentals $\$ 1.03$ at 10-11 (2d ed. 1986 \& Supp. 1987); see also Special Equip. Co. v. Coe, 324 U.S. 370, 382, 64 U.S.P.Q. (BNA) 525, 531 (1945); Hartford-Empire Co. v. United States, 323 U.S. 386, 431-32, 64 U.S.P.Q. 18, 38 (1945). 
average patent, ${ }^{166}$ led one critical economist to state that the prospect theory is "little influenced by any concern for reality." 167

Aside from this more general criticism, the prospect theory has a very specific fault: its unsupported transformation of commercial success into a crucial indicator of patentability. Kitch argues that commercial success signals that "the patent serves as the foundation for a series of now valuable contract rights."168 By emphasizing the market value of an invention, Kitch discards any worry about the inferential links between market success and patentability; the fact that the invention has commercial value means it is patentable. The prospect theory thus highlights one key patent policy - that of rewarding inventors by "increas[ing] the security of the investment process"- -at the expense of another policy, disclosure.

The prospect theory's single-minded concern with the value of the transactions surrounding an invention, rather than with the invention itself, assumes away questions about the underlying technology. Many transactions involve trade secrets and know-how, for example, but the mere existence of transactions seems a poor rationale for elevating to patentable status those trade secrets and items of know-how that happen to be involved im market transactions. After all, the qualities that have traditionally made something patentable arise not out of the innovation's value in private exchange (though this may be considerable), but out of the value the invention's disclosure confers on society at large-that is, out of its contribution to the stock of technological knowledge. Once the

166. See Mansfield, Patents and Innovation: An Empirical Study, 32 MGMr. ScI. 173, 174 (1986) (in only two of the twelve industries studied was "patent protection . . . . judged to be essential for the development or introduction of $30 \%$ or more of the inventions [made in a given year]"). The Mansfield study accords with other findings that only a few patents are highly valuable. See, e.g., Schankerman \& Pakes, Estimates of the Value of Patent Rights in European Countries During the Post-1950 Period, 96 Econ. J. 1052, 1074 (1986); cf. F.M. SCHERER, supra note 16, at 440 ("D]uring the 1970s the number of patents issued . . . ranged between 70,000 and 81,000 per year. Most covered inventions of shight technological and economic significance, but in any given year there are likely to be a thousand or so inoderately to extremely important inventions patented.").

167. F.M. SCHERER, supra note 16, at 447 n.30. This is an overstatement; Kitch did, after all, raise our level of sophistication in understanding how the reward function works. The critique, however, rings true in at least one important respeet: The prospect theory fails to recognize that in the usual case a patent circumscribes a fairly sinall corner of technology. The inventor's "prospect" is usually narrow, hemmed in on all sides by the claims of other inventors, and the limitations of his own insight. Although occasional "pioneer" patents are broad enough to cover a substantial range of inprovements to a technology, these are rare. See e.g., Continental Paper Bag Co. v. Eastern Paper Bag Co., 210 U.S. 405 (1908) (basic patent on folded paper bag aecorded wide scope against infringers). But see, e.g., Texas Instruments, Inc. v. United States Int'l Trade Comm'n, 805 F.2d 1558, 231 U.S.P.Q. (BNA) 833 (Fed. Cir. 1986) (refusing to find infringentent despite pioneering status of basic electronic calculator patent at issue). A typical patent covers different embodunents of the invention it discloses, but this is a far cry from coverage of the future development path of the technology, as the prospect theory implies.

168. Kitch, stupra note 158, at 283. 
focus returns to the invention's technical merits, the spurious inferential connection between success and significant technical advance becomes obvious, and one is thrown back to Kitch's original insight: Given this weak connection, patentability should not turn on commercial success.

Despite the fundamental defects in the inferential reasoning behind commercial success, it is a highly siginicant determmant of patentability in the Federal Circuit. It is therefore critical to study the effects of the Federal Circuit's changes in the law of secondary factors. In particular, we must examine how they will square with the traditional emphasis of the patent system on technical achievement, and the policies of disclosure and reward, and also what kinds of inventions they will encourage. Consideration of some economic research and theory is a logical first step in this evaluation.

\section{B. An Economic Critique of Commercial Success}

The first objection is that commercial success only signals that there has been an invention; it does not establish this fact directly. ${ }^{169}$ As described above, ${ }^{170}$ this objection led Edmund Kitch to criticize the use of commercial success on the occasion of the Supreme Court's Graham decision in 1966. The inferences he identified are its primary weakness; if a commercially successful innovation occurs at the end of a long chain of events, a judge-armed only with the fact of success-must reconstruct the causative elements that led to that success.

In addition to the long inferential trail needed to link commercial success with patentability, the use of this evidence also assumes an overly simplistic model of innovation. In reconstructing the events from invention to commercial success, a judge rehes on an implicit inodel of innovation, in which several firms perceive equally the market needs, they race to innovate, and the firm whose invention succeeds in the market is declared the winner/patentee. Of course, the model provides for alternative scenarios. A court could find, for example, that an invention was successful because of unpatented features, or because of the patentee's dominant position in an industry. Even in these cases, however, the analysis begins by testing the facts agamst the implicit model. Consequently, although the burden of proving facts is on the patentee, she is granted what amounts to a quasi-presumption of patentability because of the framework dictated by the commercial success doctrime. Moreover, as we have seen, this quasi-presumption appears to exercise considerable influence on the outcome of cases in the Federal Circuit. ${ }^{171}$

169. See, eg., Rich, Laying the Ghost of the Invention Requirement, 1 AM. PAT. L.A.Q.J. 26 (1972). (It has, accordingly, often been called "circumstantial evidence" of invention.).

170. See supra notes $155-65$ and accompanying text.

171. See supra note 73 and accompanying text. 
The preceding analysis requires that we consider the accuracy of the model implicit in the commercial success doctrine. How much do we know about the innovation process, and does it support or undercut the model? While patent cases provide a good deal of ad hoc discussion of these issues, we must go beyond the cases for systematic answers to our questions. This takes us to the economic study of innovation.

\section{Schumpeter and the Economic Study of Innovation}

In this section we will revisit the intellectual pedigree of the economics of innovation. The reason is simple: to understand the relevance of innovation economics to a critique of commercial success, we must first understand what this branch of economics is all about.

The study of innovation-what it is, how it comes about, and what its effects are-has long been an active branch of economics. Today it is carried on largely in the shadow of the late Joseph Schumpeter, the Austrian-American economist whose unorthodox theory of economic growth was based on the importance of technological innovation. ${ }^{172}$ To summarize somewhat brutally, Schumpeter advanced three related principles concerning innovation: (1) capitalist economies are characterized by a continuous process of "creative destruction," in which innovative technologies and organizational structures constantly threaten the status quo; (2) technological innovation provides the opportunity for temporary monopoly profits, and the pursuit of these profits has spurred the tremendous growth of the Western economies; and (3) because of the expense of conducting research, large firms are necessary to keep the engine of capitalist change going. Therefore, despite its advantages in terins of shortterin social welfare, an mdustry structure that encourages competition among many small firms is not the best structure for fostering technological innovation. ${ }^{173}$

172. For an assessment of Schumpeter's place in the development of economics, see $\mathbf{P}$. Dasgupta, The Theory of Technological Competition, in NEw Developments in THE ANALysis of MARket STructure 519 (J. Stiglitz \& G. Mathewson eds. 1986). Professor Dasgupta states: "Economists are prone to having hero-figures. In the economics of technological change, Joseph Schumpeter continues to reign as the undisputed godfather." Id. at 519.

173. See J. Schumpeter, Capitalism, SOCIALISM, AND Democracy 81-106 (3d ed. 1950). For a good summary of the basic tenets of the Schumpeterian approach, see R. NELSON \& $\mathrm{S}$. WINTER, supra note 2, at 275-81; F.M. SCHERER, supra note 2, at vii-x.

The "Schumpeterian approach" which I describe comes mainly from his later work. There is a good deal of tension between this approach and that of his earher writing, in which he tended to emphasize the importance of small entrepreneurs in the innovation process, J. SCHUMPETER, THE THEORY OF ECONOMIC DEVELOPMENT 132-33 (1934), and of "swarming imitators" in imiovation and growth, 1 \& 2 J. SCHUMPETER, Business CyCles: A THEORETICAL, HistoriCAL AND Statistical ANALYsis (1939). For a recent article concluding that the "older" Schumpeter of ThE THEORY OF ECONOMIC DEVELOPMENT, supra, more accurately describes the birth and growth of the biotechnology industry, see Kenney, Schumpeterian Innovation and Entrepreneurs in Copitalism: A Case Study in the U.S. Biotechnology Industry, 15 RES. PoL'Y 21 (1986). 
These three principles have exercised a powerful influence on the study of innovation. Since Schumpeter's time, many scholars have devoted a significant amount of energy to testing his hypotheses. ${ }^{174}$ Although a number of those hypotheses have been inodified and refined over time, Schumpeter's commitment to a vision of economics based on technological innovation has endured.

Despite its miportance in conteinporary econoinics, however, the Schumpeterian perspective has not received any sustained attention froin legal scholars, ${ }^{175}$ perhaps because those scholars interested in economics have focused most of their attention on inicroeconoinic inodeling. ${ }^{176}$ Yet the Schumpeterian perspective seeins well-suited for studying the legal rules-particularly patent laws-that influence innovation. Therefore, while a sinall body of legal literature addresses the economic effects of the patent systein, ${ }^{177}$ this Article explicitly adopts a Schuinpeterian

174. For an overview of work in this area, see M. KAMlEN \& N. Schwartz, MARKeT STRUCTURE AND INNOvATION 49-104 (1982). Kamien and Schwartz conclude that the main finding of empiricists who have tested Schumpeter's central hypothesis (a theoretical link between firm size and innovation) is that a high degree of monopoly power is unrelated to disproportionately large research expenditures. In fact, the consistent finding is that an intermediate degree of industry concentration produces the highest volume of research and development spending. Id. at 104.

175. Soine antitrust scholars have touched on eleinents of the Schumpeterian literature when commenting on the relationship between patent and antitrust law. See, e.g., Kaplow, The PatentAntitrust Interface: A Re-assessment, 97 HARv. L. REV. 1815, 1822 (1984); Ginsburg, Antitrust, Uncertainty, and Technological Innovation, 24 ANTITRUST BULL. 635, 644-46 (1979) (noting lack of progress in testing Schumpeterian hypothesis regarding the idcal industry structure for innovation, and calling for further study); see also Brodley, The Economic Goals of Antitrust: Efficiency, Consumer Welfare and Technological Progress, 62 N.Y.U. L. REv. 1020 (1988). In addition, a recent article on proteetion of coinputer software touched on soine broad Schumpeterian themes. See Menell, Tailoring Legal Protection for Computer Software, 39 STAN. L. REV. 1329 (1987).

176. The use of formal microeconomic models has proved persuasive in several areas of the law, antitrust being perhaps the inost notable. See, e.g., R. POSNER, ANTITRUST LAW (AN ECONOMIC Perspective) 8-18 (1976) (discussing the microeconomic model of monopoly).

177. See, e.g., Kitch, supra note 158; Beck, supra note 163 (both discussing the prospect theory and its application to the patent systein); see also The Economics of Patents and Copyrights, 8 RES. L. \& ECoN. passim (1986) (especially articles by Kiteh, Priest, and Cheung); Yu, Potential Competition and Contracting in Innovation, 24 J.L. \& ECON. 215 (1981); cf. DeBrock, supra note 161 (summarizing various theoretical treatments of optmial patent life).

George Priest of Yale Law School has severely criticized the entire literature on the optimal scope and term of patents. Priest, What Economists Can Tell Lawyers About Intellectual Property, 8 RES. L. \& ECON. 19, 20 (1986). He contends that law and economics works best when there is consensus on the goals to be served by a legal rule. Id. at 22-23. For example, in criminal law or environmental law, where there is common agreement on the goal (less crime and pollution), the only remaining issue is how best to achieve it. He argues that this is not the case with patent law, because no one agrees on whether more invention is necessarily good. Id. at 22 . He also asserts that "the hiterature [on patents] has taught us almost nothing," because it is not based on sound empirical research. Id. at 20.

Priest's criticisms are, however, not applicable to this Article. To the extent that my paper assumes a consensus on the goals of the patent system-first, to reward meritorious invention; second, to foster the diffusion of new teehnology; and third, to coordinate subsequent development (Kitch's "prospect function")--it escapes this criticism, since these are precisely the kinds of goals shared by criminal law and enviromnental law theorists. Note also that I rely heavily on empirical 
framework for its analysis.

The patent system, as we saw above, rewards invention directly, and innovation only indirectly. Economists since Schumpeter have distinguished between the two, ${ }^{178}$ normally describing an "invention" as a technical idea that can lead to a new product or that can be used to solve an industrial problein. They reserve the term "innovation" for the introduction of a new technology-in the usual case, the arrival of an invention in commercialized form on the market. ${ }^{179}$

Economists thus use the terms invention and innovation as they are understood by students of the patent systein. Although a few economists have distinguished between "major" innovations (for example, the steam engine or hight bulb) and "mmor" ones, the Schumpeterian tradition typically does not rely on such a distinction. ${ }^{180}$ In fact, the major/mmor distinction is both conceptually problematic and largely irrelevant for purposes of understanding how and why new products are introduced. Therefore, given the consistency in terminology, we can safely apply economic studies of innovation to our analysis of patent standards.

In our critique of the secondary factors, we will look at two hines of Schumpeterian economic analysis, one theoretical and the other empirical. The theoretical work strongly challenges the miphicit model of innovation contained in the commercial success doctrime. It demonstrates that there are many situations where competing firms have sound economic reasons to eschew innovation opportumities. Likewise, the imphicit model underlying commercial success reflects the erroneous assumption that firms often have a great deal of information about what consuiners deinand. As a consequence of this assuinption, a successful innovation may represent something other than a techirical coup and hence it is a poor proxy for the presence of a patentable techincal advance.

Empirical research supports several general conclusions from the

work in assessing the commercial success doctrine; see infra notes 205-15 and accompanying text. Finally, it should be emphasized that Priest directs his criticism primarily at relatively simple microeconomic models of how the patent system works and at more sophisticated but highly limited models of optimal patent life. The Schumpeterian perspective used in this Article is an explicit atteunt to escape from some of the restrictions of the conventional microeconomic approach, for example, its rehance on simplifying assumptions to construct manageable models of equilibrium and optimization. See generally C. FreEMAN, supra note 2, at 105-08 (arguing that numerous factors difficult to capture with simple models of rationality affect firm behavior); R. NELSON \& S. W1NTER, supra note 2 (constructing an evolutionary model of technical change frec of a number of simplifying assumptions). Also, perhaps most importantly, I have chosen to attack a simgle patent doctrine, rather than to construct yet another analytical model of the overall functioning of the patent system.

178. See R. Nelson \& S. Winter, supra note 2, at 263.

179. See supra note 3 and accompanying text.

180. See C. Freeman, supra note 2, at 57; H. Passer, The Electrical Manufacturers, 1875-1900 (1953) (Edison's light bulb); N. Rosenberg, Perspectives on Technology 9-45 (1976); F.M. Sclierer, Invention and Innovation in the Watt-Boulton Steam Engine Venture, in INNOVATION AND GROWTH: SCHUMPETERIAN PERSPECTIVES 8 (1984). 
theoretical work on innovation. Specifically, a number of studies of successful innovations highlight the critical importance of an innovating firm's sensitivity and responsiveness to the inarket. User education, service, and field support are all critical to the success of an innovation, yet they are largely unrelated to the underlying technical advance embodied in the innovation itself. A sinple conclusion follows from the Schumpeterian literature on innovation: The relative importance of nnarket-related factors, as opposed to sheer technical superiority, demonstrates the fallacy of relying on evidence of coinmercial success to prove nonobviousness.

\section{Models of Innovation as a Race}

\section{a. An Overview}

The first econonic theory we must consider shares the implicit model's assuinption that technological innovation results from a race among firms; the fimish line a firm seeks is a single, identifiable innovation whose advantages are clear to all otler firms in an industry. These studies model a firm's decisions about how mucli money and effort to expend in reaching the goal, given their expectations about rivals' research, the benefits of being first, and the benefits, if any, of being second. For reasons noted earlier, these assumptions appear to be somewhat unrealistic and hence the models only approximate how innovation actually occurs. ${ }^{181}$ However, to the extent that these nodels err, they err in favor of the implicit nodel of innovation we have discussed; that is, they tend to simplify reality in a way that is entirely consistent with the assumptions of that implicit model. Since their conclusions nevertheless undercut the imphicit model's faith in the usefulness of commercial success, they highlight the limitations of the model and hence of commercial success itself.

Although we will consider only one particular inodel of innovation, it is important to remember that there are in fact a whole family of such models, and a good deal of variety among thein. Even so, in broad out-

181. See infra notes $183-88$ and accompanying text. That the models are stylized becomes apparent when one considers the enormous differences among innovation processes in different industries and the (somewhat related) differences in the importance of patents to various industries. On this latter point, see Levin, A New Look at the Patent System, 76 AM. Econ. Rev. (PAP. \& Proc.) 199, 200 (1986); R. Nelson, S. Winter \& A. Klevorick, Results of Patent Survey, June, 1984 (unpublished manuscript on file with the California Law Review) (reporting, on basis of several thousand questionnaires, interindustry differences in the relative importance of patents, trade secrets, early entry, and other protective devices). Again, however, as with the invention/innovation distinction, the patent system forces us to oversimplify our analysis of the real world because of its identical treatment of inventions $\mathrm{m}$ all industries. Perhaps this should not be so. Nevertheless, since it is, for the time being at least, we will have to be content with stylized and thus assumption-specific models for our analysis. 
line these inodels do share several common features: ${ }^{182}$ First, coinpetition among potential innovators is modeled as a race; that is, there is a recognizable goal toward which firms coinpete. Second, devoting more resources (money, time, equipment) can accelerate the completion date of an innovation project. Third, there is some monetary reward for finishing first, although it may im some cases be sinaller than the reward to one who is second (that is, an imitator). Fourth, and finally, these models assume that firms inaximize profits; although this is subject in some cases to constraints on information and other conditions. Ultimately, this literature is unified by its focus on how profits, costs, and the intensity of rivalry affect the speed of development of a given imrovation.

With these general points in mind, we turn now to a specific example of an iumovation race model.

\section{b. The Kamien and Schwartz Model}

Economists Morton Kamien and Nancy Schwartz constructed a fairly simple matheinatical model of multi-firm races to produce innovations. Their goal was to examine the effect of varying levels of competition on the rate and direction of innovation. In order to do this, they took into account the costs and rewards of imitating as well as iimovating. ${ }^{183}$ Even in the simplest form of their model, where firms know that a given innovation can be achieved at a certain cost, Kamien and Schwartz conclude that profit-maximizing firms may choose to be imitators ratlier than innovators. They assume that eacli firm lias the techin-

182. The points that follow are taken from an overview of race models in M. KAMIEN \& N. SCHWARTZ, supra note 174, at 105-12. For a sampling of important contributions to this topic, see Dasgupta \& Stightz, Uncertainty, Industrial Structure, and the Speed of R\&D, 11 BELL J. ECON. 1 (1980) (studying the consequences of competition on invention and innovation); Lippunan \& McCardle, Dropout Behavior in R\&D Races with Learning, 18 RAND J. EcoN. 287 (1987) (analyzing the conditions prior to an invention's discovery which cause a firm to drop out of the race after investing in R\&D); Loury, Market Structure and Innovation, 93 Q.J. EcoN. 395 (1979) (formulating a inodel in which all firms' mvestments in R\&D are made under conditions of both market and technical uncertainty); Scherer, Research and Development Resource Allocation Under Rivalry, 81 Q.J. ECON. 359 (1967) (atteinpting to predict the market structure conditions inost conducive to rapid technological progress). One inportant aspect of these models is their emphasis on the "common pool problem." This is a shorthand description of what happens when too many firms are trying to exploit a common resource; the theory is that the incentives facing the firms cause them to expend inore money on developing the resource than is socially optinal. This theory was originally applied to coininon resources such as schools of fish but has been extended to include patentable technology. See Wright, The Economics of Invention Incentives: Patents, Prizes, and Research Contracts, 73 AM. ECON. REv. 691, 693-95 (1983). While the common pool concept has linitations, it is relevant in one respect: If patents actually do produce excessive spending, then courts should be wary of granting questionable patents based on cominercial success, because doing so encourages firms to engage in wasteful races over relatively insignificant inventions.

183. See M. KAMIEN \& N. SchwarTZ, supra note 174 , at 107 . This model is very assuinptionspecific. It offers little insight in situations where a new firm is considering entering a inarket, or where an established firm does not know of potential rivals and hence cannot make accurate assessments of the chances of rival entry. 
cal capability required to innovate, so that the only benefit from actually innovating is increased market share. ${ }^{184}$ At the saine time, they also assume that innovators incur certain costs that imitators might avoid. ${ }^{185}$ Among these are costs associated with spending now rather than later (because of the time value of money) and inefficiencies that result when a firm compresses its research effort to win the race. ${ }^{186}$ Importantly, Kamien and Schwartz do not say that a second firm can lower research costs by directly copying the innovator's research. The advantages come instead from the efficiency gained when research is spread over a longer period of time. ${ }^{187}$

Another critical feature of the Kamien and Schwartz model is that it incorporates the notion of opportumity costs. Specifically, the model assumes that some potential innovators would replace existing products with new ones, thereby sacrificing a known revenue stream for prospective benefits such as gains in market share or higher margins. ${ }^{188}$ This valuable feature allows us to focus on a potential innovator's assessinent of economic feasibility. The model is further simplified by assuming that all firms know which inventions are technically possible, and that a given invention can be achieved with a known level of resource expenditure. Although these assumptions do not reflect the true complexity of many invention project decisions, they do focus attention on one critical coinponent of the decision process often overlooked by both students of the patent systein and patent lawyers: market strategy, as opposed to technical feasibility.

The Kamien and Schwartz model's recognition of opportunity costs

184. Id. at $112-13$.

185. Id. at 116 .

186. In this respect, Kamien and Schwartz follow F.M. Scherer's theoretical work on the "timecost tradeoff," as refined by the empirical studies of Scherer and Edwin Mansfield, who found that firms traded time against expense when making research expenditure decisions. See E. MANSFIELD, J. RAPAPORT, J. SCHNEE, S. WAGNER \& M. HAMBURGER, RESEARCH AND INNOVATION IN THE MODERN CORPORATION 126-56 (1971); M.J. PECK \& F.M. SCHERER, THE WEAPONS ACQUISITION Process: AN ECONOMIC ANALYSIS (1962); F.M. Scherer, supra note 2, at 59-61, 120-23 (summarizing early views on time vs. cost tradeoff, 1952-1963, and subsequent developments). The imderpinnings of the time-cost tradeoff were questioned by Richard Nelson in 1961. He postulated that firms set as their objective either time or cost minimization, and that their decisions did not conform to the continuous trade-off function posited by Scherer. See Nelson, Uncertainty, Learning, and the Economics of Parallel Research and Development Efforts, 43 REV. OF ECON. \& STATISTICS 351,362 (1961).

187. Since inclusion of direct copying in the model would amount to an assumption that no legal protection was available to the innovator, it would be awkward to use this model in a paper on patents.

188. See M. KAMIEN \& N. SchwARTZ, supra note 174, at 113. This well-known phenomenon is sometimes called "cannibalism," for the effect of eating into an established market with a new product. See, e.g., Rumelt, Theory, Strategy, and Entrepreneurship, in THE CompetrTIVE Challenge: Strategies for Industrial InNovation and Renewal 137, 149 (D. Teece ed. 1987). 
supplies a framework for analyzing several key situations. A firm will decide not to innovate-even though it has the technical know-how to do so-whenever the firm's revenue from existing products is high enough to offset the risk of being preempted by an innovator. ${ }^{189}$ The level of this risk is determined by the individual firm's assessment of the probability of preemption by an innovator. ${ }^{190}$ Smce each firm makes its own subjective a priori determination of that risk, the model accounts for the possibility that a firm might guess wrong. ${ }^{191}$

A firm that underestimates the likelihood or speed of rival entry will lose the race to the market. When a firm guesses incorrectly about the revenue from an innovation versus existing products, it will lose market

189. In terms of the basic Kamien and Schwartz model, and with apologies to those not interested in calculus, the situation facing the firm deciding whether or not to innovate looks like this:

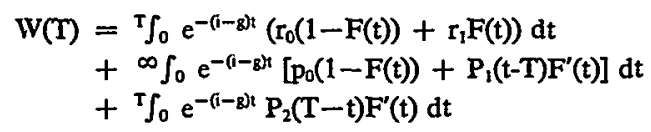

M. KAMIEN \& N. SCHWARTZ, supra note 172 , at 116 .

Where:

$W(T)=$ the firm's expected profit stream

$\mathrm{t} \quad=$ a moving time variable, i.e., any moinent in time

$\mathrm{T}=$ time at which the firm innovates

e $\quad=$ base of natural logarithm; 2.71828 (refiects assumption of exponential revenue growth)

i $=$ firm's discount rate

$\mathrm{g} \quad=$ industry growth rate

$r_{0}=$ firm's revenues prior to introduction of innovation

$r_{1} \quad=$ firm's revenues after rival introduces its innovation

$F(t)=$ firm's assessment of likelihood that one of its rivals will have introduced its innovation by tine $t$; thus, $(1-F(t))$ is the probability tliat rivals have not introduced innovation

$\mathrm{p}_{0}=$ firm's fiow of receipts from introduction of innovation until introduction of rival's innovation

$P_{1} \quad=$ firm's capitalized stream of receipts after both its and its rival's innovations; a lump sum reflecting revenue in the mature years of the project's life

$F^{\prime}(t)=$ probability density of rival entry; this ineans the cumulative probability that one of the firm's rivals will introduce an innovation in the next moinent

$\mathbf{P}_{2} \quad=$ firm's capitalized stream of receipts after it imitates rival's innovation; again, a lump sum reflecting revenue through the end of the product's life

Kamien and Scliwartz go on to explain that:

To understand this, note that so long as the firm lias not introduced a new product (i.e., $t$ $<T$ ), the firm gets $e^{\beta T} r_{0}$ if no rival has innovated by $t$ (probability 1-F(t)) and gets $e^{s t} r_{1}$ if a rival has done so by $t$ (probability $F(t)$ ). If the firm innovates but its rivals lave not done so (probability $1-F(t), T t$ ), it gets $e^{s t} p_{0}$. It gets a stream worth $e^{s t} P_{1}(t-T)$ if it was first but an initator appears at $t$ (probability density $F^{\prime}(t), t>T$ ). Finally, the firm gets a stream worth $e^{8 T} P_{2}(T-t)$ at $T$ as follower if a rival innovates first at $t$ (probability density $F^{\prime}(t), t$ $<\mathrm{T}$ ).

Id. If you have followed things this far, it is easy to see how certain values for $x_{0}, r_{1}$, and $F(t)$ make innovating unprofitable, despite the availability of the technical know-how to do so. Thus, if the model is correct, it can be used to describe situations where an obvious invention is passed over, and a rival firm innovates. In these eases, a commercially successful innovation should not be used as proxy for an underlying invention; coinmercial success is a bad indicator of a patentable (nonobvious) invention.

190. Id. at 114 .

191. Id. 
share to the innovator. In the latter case, the firm has simply made a bad estimate of the commercial prospects of the innovation. ${ }^{192}$ It should be noted that the model also envisions situations where a firm guesses correctly about the prospective revenues from an innovation, but still chooses not to innovate because of high current revenues on existing products. ${ }^{193}$

By separating a firm's revenue predictions from its assessment of technical feasibility, the Kamien and Schwartz model lends analytical rigor to the skepticism some judges ${ }^{194}$ have felt intuitively: sometimes firms decide not to innovate; they do not always try and fail. When this is true, the commercial success standard points a court in the wrong direction. In cases where competitors choose not to innovate, the elaborate inferences that the commercial success doctrine demands of the factfinder are not warranted, and commercial success evidence falsely indicates patentability. In other words, the implicit model of innovation embodied in the doctrine fails to reflect accurately the realities of the marketplace.

\section{A Dynamic Model Of Innovation}

Two otlier economists, Ricliard Nelson and Sidney Winter, have designed a model which, altlough it differs in many respects froin innovation race models, highlights many of the same weaknesses in the commercial success doctrine's implicit model of innovation. Nelson and Winter simulate interfirm research and development (R\&D) rivalry over time as part of a much more complex attempt to model what Scliumpeter called "the perennial gale of creative destruction"195 - the constant

192. This is not a rare phenomenon. In the 1920s the German chemical combine IG Farben offered to sell all of its synthetic rubber patents to the international rubber cartel, believing that the natural product would retain its major price advantage. Needless to say, they were wrong. See $C$. Freeman, supra note 2, at 62. See generally L. NASbeth \& G. RAY, The Diffusion of New INDUSTRIAL PROCESSES (1974) (stressing the haphazard and subjective nature of firms' ex ante estimates of the profitability of an innovation).

193. See, e.g., Baldwin \& Childs, The Fast Second and Rivalry in Research and Development, 36 So. ECON. J. 18, 21-22 (1969). The authors argue that a firm with monopoly power, because of its reputation and ability to distribute, will be favored as an imitator. Their theory has intuitive appeal as I write this Article on my IBM PC. See also Katz \& Shapiro, R\&D Rivalry with Licensing or Imitation, 77 AM. ECON. REV. 402, 415 (1987) (sets out a model of R\&D races, concluding that industry will develop major innovations only if the costs of postdevelopment licensing or imitation are prohibitive); Lippman \& McCardle, Dropout Behavior in R\&D Races with Learning. 18 RAND J. ECON. 287, 289 (1987) (game theoretic model of innovation race incorporating notion that the value of an identical innovation may be different for different firms depending on such factors as marketimg strength). Still, many economists have identified very substantial advantages attaching to innovators ("first movers"). See F.M. SCHERER, supra note 2, at 62-63, and sources cited therein (summarizing the first mover literature and its response to the Baldwin and Childs thesis).

194. See, e.g., supra notes 49-51 and accompanying text.

195. J. SCHumpeter, CAPITAlism, SOCIALISM AND Democracy 84 (3d ed. 1950). 
dynamic forces of innovation and competition. ${ }^{196}$ Their computer simulations avoid analysis based on equilibrium, maximization, and optimization, replacing these with notions of limited rationality in decisionmaking and a constant searcl for innovations.

Nelson and Winter's model is based on firms' pursuit of individualized research strategies. Unlike the race models, this model does not assume perfect knowledge about research projects or their feasibility. Instead the model pictures firms as organizations that adopt suboptimal "search strategies" when pursuing research. These strategies are essentially a series of guesses about the most promising technologies a firm might explore to meet its goals. Over time, the market "selects" for the most successful strategies; the firms that adopt the strategies survive and are perpetuated. Like its biological analogue, this evolutionary process can presumably be affected by random processes, including lucky guesses and research serendipity. ${ }^{197}$

Whereas the inodel of innovation underlying the commercial success doctrine assumes that many firms perceive market needs and then race to innovate, Nelson and Winter's model (based on certain einpirical work) ${ }^{198}$ depicts a competitive environment in which firms stress differing R\&D criteria and vary their behavior depending on their experience and the messages they receive from the inarket. Thus, because search strategies differ, one firm's promising technology might not appeal to anotlier, even though both firms believe the technology itself is feasible.

The coinpetitive environment described by Nelson and Winter las two important features. First, the invention-innovation distinction is deeinpliasized. ${ }^{199}$ Their inodel assumes that firms plan their research strategy in response to botl business and technical risks: "If the innovation is to persist and expand in use, the firm must find a new product or

196. Actually, a number of recent theoretical articles on $R \& D$ races construct models based on game theory to simulate "dynamic" interactions among firms. However, even these models are concerned with finding a set of equilibria such that the goals of one firm and the behavior and strategy of other firms produce predictable results-in effect a series of equilibria points, dependent on other firms' behavior. See, e.g., M. KAMIEN \& N. SchwarTZ, supra note 174, Chapter 5; Grossman \& Shapiro, Dynamic R\&D Competition, 97 EcoN. J. 372 (1987).

197. See R. NELSON \& S. WiNTER, supra note 2, at 246-72.

198. See M. Kamien \& N. SchWARTZ, supra note 174, at 58-64; R. NELSON \& S. WiNTER, supra note 2, at 202-05.

199. Nelson and Winter in fact criticize Schumpeter's original version of it as "much less useful than it used to be." R. NELSON \& S. WinTER, supra note 2, at 263. They are not alone in making this point. See, e.g., P. Dasgupta, supra note 172, at 519-20 (criticizing Schumpeter's "obsession with the act of innovation"). Nathan Rosenberg has also questioned attempts by historians to identify the year when certain inventions were first conceived and reduced to practice. Rosenberg, Problems in the Economist's Conceptualization of Technological Innovation, in PERSPECTIVES ON TECHNOLOGY 71 (1976); cf. Menell, Tailoring Legal Protection for Computer Software, 39 STAN. L. REV. 1329, 1337-38 (1987) (discussing interrelationship of mnovation and diffusion in making a product socially valuable). 
process profitable to produce or employ . . .."200 Second, firms differ widely in their approaches to research and development and their preferences for innovation or imitation. The model assumes that firms "cannot hope to find optimal strategies;" instead, firms employ "rather mechanical procedures ... for quickly narrowing the focus to a small set of alternatives and then homing in on proimsing elements within that set."201 Those procedures may result from the nature of the technology itself (in which case they are said to incorporate the "natural trajectory" of the technology), from individual firms' experience, or from both. ${ }^{202}$ As a result, each firm's search procedure reflects its own experience and preferences regarding both technical feasibihity and market receptivity.

Froin this brief sketch, it should be apparent that the Nelson and Winter model provides a more coinplete view of innovation decisions than the imphicit inodel of the courts in patent cases, which systematically minimizes the importance of busmess factors. Under the dynamic evolutionary inodel, a firm's search procedures may cause it to disregard a technological possibility because of its development costs or commercial prospects. ${ }^{203}$ Firms, acting on incomplete information, may leave the inarket open for another innovator, whose search procedure leads to a better guess. Finally, firms may simply wait to imitate the innovator. ${ }^{204}$ In any of these circumstances the model suggests that a court would be mistaken to infer a high level of technical achievement from an innovator's commercial success. Business considerations may be largely responsible for a successful innovation.

\section{Empirical Evidence on Innovation}

\section{Studies of Innovation}

Many features of the Nelson and Winter model are supported by

200. R. Nelson \& S. Winter, supra note 2, at 264; see also P. Stoneman, Economic ANalysis of Technological Change 13-27 (1983) (discussing importance of profitability in converting an invention into an innovation and then into a staple product).

201. R. NeLSON \& S. WINTER, supra note 2, at 255.

202. Id. at 258. Courts have recognized this principle. See, e.g., State Indus., Inc. v. Rheem Mfg. Co.,769 F.2d 762, 763, 227 U.S.P.Q. (BNA) 375 (Fcd. Cir. 1985) (speaking of the "natural evolution of the prior art").

203. R. NELSON \& S. WINTER, supra note 2, at 203, 255. An example of this is presented in Leinoff v. Louis Milona \& Sons, Inc., 726 F.2d 734, 739-40, 220 U.S.P.Q. (BNA) 845, 848-49 (Fed. Cir. 1986). The patentee had devised a method of inserting leather strips under the surface of fur coats, giving them the appearance of being striped. The patent was challenged for obviousness, but the Federal Circuit relied substantially on the suceess of the innovative coats and upheld the patcnts. Disputing the use of commercial success as evidence of nonobviousness, competitors of the patentce contended that the invention had never occurred to them; they had always assumed that natural fur was preferred by the consumer. The court found this argument unpersuasive. But see id. at 743, 220 U.S.P.Q. at 852 (Nies, J., dissenting).

204. See R. NELSON \& S. WINTER, supra note 2, at 212. 
empirical studies of the innovation process, ${ }^{205}$ which have found that successful innovations usually spring from a combimation of product development and market knowledge. Rarely does a successful innovation result from one of these two factors alone. ${ }^{206}$ Differences in the way firms explore these combinations lead to different innovational approaches and, ultimately, different degrees of success.

For example, a number of studies led by British economist Christopher Freeman point in this direction. ${ }^{207}$ Freeman's group studied a large number of successful innovations in Great Britain. By comparing pairs of successful and unsuccessful innovations, they found that successful innovators incorporated a detailed understanding of consumer needs into their product development and marketimg plans. ${ }^{208}$ Of the differences between success and failure, Freeman states that

[t] hose which came through most strongly were directly related to marketing. In some cases they might be regarded as obvious, but the case studies showed that even the most obvious requirements were sometimes ignored. Successful attempts were distinguished frequently from failure by greater attention to the education of users, to publicity, to market forecasting and selling... and to the understanding of user requirements. ${ }^{209}$

205. See id. at 202-05 (citing K. PAvitr, The CONDITIONS FOR Success IN TECHNOLOGICAL InNOVATION (1971)); C. FReEMAN, supra note 2, at 124; M. KAMIEN \& N. SCHWARTZ, supra note 174 , at 202-05.

206. Of course, knowledge of the market can often find its way into the technical side of product developinent; a inarket-aware innovation is not necessarily a minor technical advance. However, with a inarket-sensitive product the inere fact of success says nothiug about the relative contributions of inarket knowledge and technical superiority. Moreover, since economic research tells us that successful innovations are inost often highly market-sensitive, conunercial success aloue is an enigma, emanating froin two sources in unknown (and perhaps unknowable) proportions. See generally Mowery \& Rosenberg, The Influence of Market Demand Upon Innovation: A Critical Review of Some Recent Empirical Studies, in INSIDE THE BLACK Box: TECHNOLOGY AND ECONOMICs 193, 228-35 (N. Rosenberg ed. 1982) (narket demand and technological opportunity each necessary but individually insufficient for innovation). The Rosenberg \& Mowery article was written in response to sonie research suggesting that nuarket deniand was the critical stilnulus behind innovation. See, e.g., J. SCHMOOKLER, INVENTION AND ECONOMIC GROWTH (1966). Recent work suggests that industry lifecycles nay play a role in the relative inportance of "demand-pull" and "technology-push" factors. See Walsh, Invention and Innovation in the Chemical Industry: DemandPull or Discovery-Push?, 13 Res. PoL'y 211 (1984).

207. The studies are described and sumnarized in C. Freeman, supra uote 2, at 113. In addition, many examples froin economic history support the conclusions of these studies. For instance, Nathan Rosenberg, a gifted historian of invention and innovation, found that Thomas Edison supplemented his technical research by naking a very thorough study of the gas industry. According to Rosenberg, Edison believed that he had to understand the existing inarket for illumination if he hoped to revolutionize it. As Rosenberg states, Edison "deliberately patterned many of his practices upon those of the gas industry. Edison's commercial genius resided in an extremely shrewd awareness of those respects in which innovation called for continuity as well as discontinuity." Rosenberg, supra note 199, at 75 (footnote omitted).

208. C. FREEMAN, supra note 2, at 124.

209. Id. By contrast, several variables that measured aspects of technical sophistication were found to be irrelevant to the success of innovations. There was, for example, no relationship between 
Several other empirical studies support Freeman's conclusion. For example, a group of economists at the University of Manchester concluded that "technological innovation ... nuust involve synthesis of some kind of need with sone kind of technical possibility."210 Likewise, after a survey of unsuccessful innovations in Canada, a group of researchers concluded that "[m]ost of the entrepreneurs were unable to see the linkage between product innovation and narketing innovation .... Most of the new product development was carried out and implemented before any attempt was niade to assess the niarket potential and the costs of penetrating the narket."211

A detailed study of 203 new products by R.B. Cooper and E.J. Kleinschmidt of the McMaster University Business School in Canada revealed a similar pattern. ${ }^{212}$ Although Cooper and Klemschmidt found that "product advantage" was the most miportant determinant of success, they also discovered that this variable had a number of dimensions. Typically, product advantage was present when an innovation had unique features for the custoner, was of higher quality than competitive products, and was perceived as superior to competitive products in some respect. ${ }^{213}$ Most importantly for our purposes, they found that "technological characteristics of the product, such as the use of new or advanced technology, product innovativeness, and the role of industrial design do not appear to influence [the] Fimancial Performance [variables in their study]."214 In other words, there was not necessarily any strong relation-

the academic qualifications of technical researchers and the chances of success. Nor was the number of scientists and engineers on the innovating firm's board of directors a useful predictor of success (although in almost every case there were some engineers or scientists on the board). Id. at 117, 123.

210. J. Langrish, M. Gibbons, W. Evans \& F. Jevons, Wealth from KNOWledge 57 (1972).

211. Litvak \& Maule, Managing the Entrepreneurial Enterprise, 37 Bus. Q. 42, 46-47 (1972); see also C. FREEMAN, supra note 2, at 127-29.

212. Cooper \& Kleinschmidt, New Products: What Separates Winners from Losers?, 4 J. ProD. INNov. MGMT. 169 (1987) [hereinafter New Project Products] (deseribing Project "New Prod," study of 203 successful and unsuccessful innovations); Cooper \& Kleinschmidt, What Makes a New Product A Winner: Success Factors at the Project Level, 17 R\&D MGMT. 175 (1987) [hereinafter Success Factors] (same study); see also Cooper, The Dimensions of Industrial New Product Success and Failure, 43 J. MkTG. 93 (Summer 1979).

213. New Products, supra note 212, at 176, Table 2; Success Factors, supra note 212, at 182 ("The most important product variables [that correlate with] Financial Performance are [first, whether] [t]he product was superior to competitive products in the cyes of the customer").

214. Success Factors, supra note 212 , at 182 . This conclusion is borne out by a recent study of successful innovations that analyzes the conditions under whieh a pioneer or first mover in a new technological field will succeed over subsequent entrants, as well as those situations wherc the subsequent entrants (or "poachers") will succeed. When Entering Growth Markets, Are Pioneers Better than Poachers?, Business Horizons, Mar.-Apr. 1986, 27, 29-30 (pioneers won in seven out of twelve cases, including Sony's Walkman, Litton's microwave oven, and GE's Sentry home smoke detector; "poachers" won in other ficlds, including Matsushita's VCR (over pioneer Sony) and Texas Instruments' calculators (over pioneers Bomar and Cannon)); see also Calantore, di Benedetto \& Mcloche, Strategies of Product and Process Innovation: A Loglinear Analysis, 18 R\&D MGMT. 1, 1 
ship between technical achievement (that is, invention) and a commercially successful innovation. In many cases, then, the inferential link between success and patentability-the presence of a significant technical advance-is weak. Thus, this research appears to undercut one of the chief assumptions behind the use of conimercial success to establish patentability.

In summary, the various empirical studies agree that successful new products are launched with detailed knowledge of market conditions. Although technological enhancements are by no means insignificantindeed, sonie of the studies assume appreciable advances in technol$\mathrm{ogy}^{215}$ - the researchers consistently emphasize the inarket-orientation of successful new products. These conclusions cast doubt on the rehability of comniercial success as an indication of nonobvious imvention. They suggest that it is not differences from the prior art in the field, but rather other factors-such as the skill with which technology is embedded in new products together with deft marketing-which determine that an innovation will be successful. Accordingly, before relying on commercial success as proof of true invention, courts should carefully review all the market-side factors attending the innovation by examining evidence of market sensitivity in product design and dehvery (for example, service), as well as market stimulation (imcluding advertising and proinotions).

\section{Selected Cases: Further Empirical Support}

A review of some actual cases will illustrate some of the themes we have been discussing. Several pre-Federal Circuit cases illustrate that some courts are sensitive to the nontechnical causes of commercial success highlighted in the economic hiterature on innovation. In Shelco $v$.

(1988) ("Soine firms have been particularly successful utilizing a strategy of borrowing innovative product and process ideas developed externally and applying them to serve their inarket segments better.") (citations omitted). Note that in some cases, the subsequent entrants may simply be better at translating the underlying invention into a workable, cost-effective product. $C f$. Ginn \& Rubinstein, The R\&D/Production Interface: A Case Study of New Product Commercialization, $3 \mathrm{~J}$. PROD. INNOV. MGMT. 158 (1986) (study of "scale up" efforts at a major chemical coinpany relating to three product innovations concluding that communication between product developinent and manufacturing departments is key to successful scale up).

215. This is the case with the study reported by Freeman. See C. FREEMaN, supra note 2, at 114-15. It is also interesting that Freeman found that patents were alinost always obtained, but only one failure attributed the lack of success to its rivals' patent status. Id. at 117. Thus, at least to the extent that the granting of a patent dernonstrates soine technical advance, Freeman's findings further deinonstrate that market-side factors are at least as inportant as, if not inore inportant than, technical features in the success of an innovation. And there is soine evidence that in Great Britain (where Freeman's studies were carried out), patents inay refleet teehnical advance, at least insofar as British courts are careful to limit their use of commercial success as an indicator of patentability. See J. Bochnovic, The Inventive Step: Its Evolution in Canada, the United Kingdom, AND THE UNITED STATES 72-75 (1982) (cominercial success carries weight in British courts only when accompanied by evidence of others' failure to solve the problem). 
Dow Chemical Co., for instance, the trial court recognized the impact of market-related factors on the commercial success of the invention. ${ }^{216}$ In this case, Shelco accused Dow of infringing Shelco's patent on a formula for oven cleaner. In support of the patentability of its invention, Shelco presented evidence of substantial commercial success. Dow countered with evidence that it had developed an almost identical formula but had hesitated to introduce it because of questions over its safety. The court found Dow's evidence convincing and held Shelco's patent invalid for obviousness. ${ }^{217}$ In keeping with the Nelson and Winter model, these firms pursued different search strategies based on their differing sensitivity to the extra risk inherent in the more caustic cleaning foam. Moreover, consistent with the predictions of the Kamien and Schwartz model, Dow already had an oven cleaner on the market, and therefore had less motivation to quickly introduce the new formula. Thus, the Shelco case aptly illustrates how commercial success may reflect market incentives and preferences rather than pure technical achieveinent.

In several other cases, courts have denied patents when a patentee's competitors had an insufficient incentive to commercialize a product, even though those competitors had determined that the product was technically feasible. ${ }^{218}$ One case, Bausch \& Lomb. Inc. v. Barnes-Hind/ Hydrocurve, Inc. ${ }^{219}$ is typical. Bausch \& Lomb had obtained a patent on a technique for marking contact lenses using a laser; the marks helped wearers distinguish the right lens from the left. Barnes-Hind introduced evidence that it had developed the same technology but had waited to introduce it until its sales increased enough to justify the expense of the

216. 322 F. Supp. $485,508,168$ U.S.P.Q. (BNA) 395, 414 (N.D. Ill. 1970), aff'd, 466 F.2d 613 (7th Cir.), cert. denied, 409 U.S. 876 (1972).

217. A strikingly similar tale is told by Christopher Freeman in his description of the development of pressure-intensive cracking processes in the petroleum industry. See C. FREEMAN, supra note 2, at 33-34. William Burton had invented a high-pressure process for Standard Oil in 1910, but fear of explosions on the site of the first plant made management wary, and so the introduction of the process was delayed. But in 1911 Standard Oil was split up by an antitrust decree, and one of the smaller Standard Oil companies was assigned the Burton patent. This coinpany immediately impleinented the invention. Id. at 33-34.

218. See Orthopedic Equip. Co. v. Umited States, 702 F.2d 1005, 1013, 217 U.S.P.Q. (BNA) 193, 200 (Fed. Cir. 1983) (appellant's failure to prove a long-felt need for his invention in industry explains why no other businessman had undertaken the relatively simple steps necessary to perfect the invention); Bally Mfg. Corp. v. D. Gottlieb \& Co., 222 U.S.P.Q. (BNA) 681, 686 (N.D. Ill. 1984) (oral opirion by Grady, J.) ("The incentive to convert over [to pinball machines with microprocessors] wasn't the greatest ineentive I have ever heard evidence about. The electromechanical machines were selling well ...."); see also Bausch \& Lomb, Inc. v. Barnes-Hind/ Hydrocurve, Inc., 226 U.S.P.Q. (BNA) 780, 783 (N.D. Cal. 1985), vacated on other grounds, 796 F.2d 443, 230 U.S.P.Q. (BNA) 416 (Fed. Cir. 1986), cert. denied, 108 S. Ct. 85 (1987), discussed infra at text accompanying note 219. But see Fromson v. Advance Offset Plate, Inc., 755 F.2d 1549, I557, 225 U.S.P.Q. (BNA) 26, 32 (Fed. Cir. 1985) (long publicity of alleged eeonomic rcward to miprover makes it "bizarre" to claim that the invention was obvious).

219. 226 U.S.P.Q. (BNA) 780, 783 (N.D. Cal. 1985), vacated on other grounds, 796 F.2d 443, 230 U.S.P.Q. (BNA) 416 (Fed. Cir. 1986), cert. denied, 108 S. Ct. 85 (1987). 
new technique. The district court accepted the evidence and found the patent invalid, recognizing that commercial success is not dispositive of nonobviousness without consideration of competitors' financial considerations, market position, and similar nontechnical factors.

In a recent Federal Circuit case, Hybritech, Inc. v. Monoclonal Antibodies, Inc. ${ }^{220}$ the patent challenger presented facts suggesting that extrinsic factors unrelated to the technical merits of the patentee's invention accounted for its commercial success. Yet, unlike the courts in Shelco and Bausch \& Lomb, the Federal Circuit downplayed the importance of these factors; it relied heavily on commercial success in upholding the validity of the patent. In Hybritech, the plaintiff accused Monoclonal Antibodies, Inc. ("MAb") of making and selling diagnostic test kits that infringed Hybritech's broad patent in the field. In response to MAb's defense that the patent was invalid for obviousness, Hybritech introduced evidence of commercial success. MAb followed a conventional strategy in defending against Hybritech's infringement suit, calling attention to Hybritech's ostensibly large advertising budget im an effort to attribute Hybritech's success to promotional skill rather than to the technical advantages of its products. As one might have predicted, this strategy did not succeed under the generous "nexus" standard. The Federal Circuit relied heavily on Hybritech's success to reverse the trial court and uphold the patent. ${ }^{221}$

Although the court found Hybritech's technology nonobvious, the evidence suggests that it was in fact an obvious extension of the prior art. The court virtually ignored the fact that there might have been another reason for Hybritech's early success: lack of a profit incentive for other researchers in the field. Hybritech's commercial success was the result not of its own original research but of its early commercially oriented apphication of well-understood scientific techniques. Hybritech was founded in 1978, and it began investigating commercial apphications of monoclonal techniques between 1978 and 1980, during the earliest stages of the biotechnology industry. ${ }^{222}$ At the time of its research, most of those "skilled in the art" were researcl scientists, not entrepreneurs. They clearly understood that inonoclonals were useful as lab assays, but they had no interest in adapting and scaling up the technique for use in

220. 802 F.2d 1367, 231 U.S.P.Q. (BNA) 81 (Fed. Cir. 1986), cert. denied, 107 S. Ct. 1606 (1987).

221. Id. at 1382-83, 231 U.S.P.Q. (BNA) at 92-93.

222. See M. KenNEY, BIOTEChNOLOGY: The UNIVERSITY-INDUSTR1AL COMPLEX 138 (1986). What Kenney calls "the gold rush atmosphere" of biotechnology startups began in 1979, by which time Hybritech had already set up its laboratories and begun experimenting. See Hybritech, $802^{\circ}$ F.2d at 1370. Thus Hybritech had a headstart-a significant one, given the rush of new firms into the industry. 
commercial diagnostic kits. ${ }^{223}$ As an early entrant in the field-and the earliest startup in monoclonal research ${ }^{224}$ - Hybritech had a head start in developing the technology for commercial applications.

The opinion of the trial court demonstrates that it was aware of Hybritech's market advantage. As the trial court noted, MAb produced a parade of notable scientists, all of whom testified that Hybritech's application of the monoclonal technique was obvious. ${ }^{225}$ Accordingly, the trial court explicitly discounted Hybritech's commercial success, saying that it "may well be attributed to the business expertise and acumen of [Hybritech's] personnel, together with its capital base and marketing abilities."226 Hybritech's early entry, and other experts' lack of interest in commercial apphications, are precisely the kind of nontechnical or market advantages so often associated witl a successful innovation. Unfortunately, it is also precisely the kind of factor overlooked by the Federal Circuit in its application of the commercial success doctrine. A careful and detailed analysis of these circumstances sliould have led the court to follow the trial court in discardimg the evidence of commercial success and loldmg that Hybritecli's invention was obvious. ${ }^{227} \mathrm{By}$ giving short shrift to these considerations, lowever, the court's reconstruction of the causes of success was incomplete, leading it to uphold a patent it slould liave invalidated.

The Federal Circuit demonstrated its insensitivity to the full range of causes behind commercial success in another case, Alco Standard Corp. v. Tennessee Valley Authority. ${ }^{228}$ In this case the Federal Circuit

223. See M. KENNEY, supra note 222, at 137.

224. The Nobel Prize-winning discoverers of monoclonals, for instance, had declined to patent their pioneering results. See G. Tortora, B. Funke \& C. Case, Microbiology: AN INTRODUCTION 448 ( 2 d ed. 1986).

225. 623 F. Supp. 1344, 1353, 227 U.S.P.Q. (BNA) 215, 221 (N.D. Cal. 1985).

226. Id.

227. The court did mention the "early leader" argument. See Hybritech, 802 F.2d at 1382-83, 231 U.S.P.Q. at 92-93. However, it dismissed the argument almost summarily, saying "it is clear to us on the entire record that the commercial success here was due to the merits of the claimed invention .... This is not the kind of merchandise that can be sold by advertising hyperbole." Id. at 1383-84, 231 U.S.P.Q. at 93. The court did not address the full breadth of MAb's argument at trial; $\mathrm{MAb}$ had argued that monoclonal antibodies were not readily available in 1979, and that Hybritech simply used its superior capital position and proprietary relationship with Abbot Labs, Inc. to access the necessary tools faster than anyone else. A trade press account of the trial argument quoted MAb's counsel as stating: " 'It wasn't because it wasn't obvious that no one did it . . . no one else could screen 150,000 clones to pick out the 1 or 2 best ones." Exclusivc Case Coverage, BioEngineering News, Sept. 5, 1985, at p.2, col.3; see also P. ClARK, Protection of Biotechnology-Related Intellectual Property: State of the Art, in ADVANCED TOPICS IN INTELLECTUAL Property MaNAGement, (1987) 175, 186 (Massachusetts Continuing Legal Education No. 87-111 Pub. ("The district court judge said that '[o]nce the scientific community had the monoclonal antibody, it was obvious and logical to ... use them in known assays. . . ' Many scientists and patent lawyers agree with this simple assessment of the Hybritech patent.").

228. 808 F.2d 1490, 1 U.S.P.Q.2d (BNA) 1337 (Fed. Cir. 1986), cert. dismissed, 108 S. Ct. 26 (1987). 
upheld the validity of a patent partly as a result of the patentee's strong showing of commercial success. Recall from our earlier discussion of the case, ${ }^{229}$ however, that the patentee's turbine testimg device was only a small component of its overall testing service, and that the firm's reputation for superior service was arguably the most important element in its success. Careful consideration of these facts should lave led the court to disregard Alco's commercial success, which was the result more of market sensitivity than technical invention. ${ }^{230}$ Instead, the court concluded that commercial success (among other secondary factors) strongly indicated the nonobviousness of the device's technical features, and the patent was upheld. ${ }^{231}$ Once again, the court overlooked an important alternative explanation for an imvention's commercial success, and as a result upheld a patent that it quite possibly should have invahdated.

Each of the above cases demonstrates deficiencies in the conceptual underpinnings of the commercial success doctrine. These deficiencies persist even when the Federal Circuit scrupulously applies its nexus requirement. For example, in each of the cases discussed above-Alco Standard, Shelco, and Hybritech-the innovator's success was based to some extent on the technical features of the underlying mvention. Therefore, in each case there was a nexus between the imvention and the commercial success. The problem is that in eacli case it was still unclear whether the invention was nonobvious at the time it was made. Altliough it is true that some new technical features were imcorporated into a successful product, the magnitude of the technical advance cannot be determined from the mere fact of success. In other words, the patentability of the invention cannot be comfortably inferred from the success of the innovation if that success results from an aggregation of botll market- and technology-related factors.

\section{IV \\ The Consequences of CurRent Secondary Factor DOCTRINES}

As the theoretical models reviewed above predict, and as the empirical studies confirm, commercial success is a poor indicator of significant technical advance. These infirmities appear on a number of levels. The theoretical hiterature, supported by empirical studies, points out that commercial success can result from a number of factors, only one of which is the technical superiority of the innovation. This finding weak-

229. See supra notes $95-96$ and accompanying text.

230. See supra notes $205-11$ and accompanying text (concerning role of market sensitivity in commercial success).

231. See supra notes $95-96$ and accompanying text. 
ens the first link described by Kitch ${ }^{232}$ in the inferential chain associated with commercial success. ${ }^{233}$ The economic literature, especially the Nelson and Winter "dynamic" model of firm competition, undermines the second link by illustrating situations where firms fail to realize the potential for a successful new product. Furthermore, in some cases firms with entrenched product hines have no incentive to pursue an invention even where it is apparent. Such inarket-related factors tend to weaken the third causal link. Finally, we have observed that the first firm on the scene is not always successful, so that in soine cases the firm that does achieve success with an innovation is not necessarily the first to perfect a particular invention. ${ }^{234}$

In sum it appears that the Federal Circuit has placed its faith in an unrehable indicator of patentability. The question remains, what does this cost us? Why should it be cause for concern?

\section{A. The Costs of Commercial Success}

There are real costs when patents are awarded or upheld simply on the basis of commercial success. The Patent Office and the courts reward firms for strategies, assets, and inarket conditions completely unrelated to technical advancement. For example, as the Hybritech case suggests, patent vahidity may turn on the (perhaps fortuitous) decision to adopt a rapid innovation strategy - a decision that may or may not be related to the presence of an underlying invention. Patentability doctrine should not rely so heavily on such nontechnical factors; the law should make the innovator's choice of strategy irrelevant. The patent system should invite a multiplicity of innovational strategies-speedy and slow, aimed at one market or another-while preserving the essence of the patent validity determination, technical nonobviousness.

When courts reward nontechnical factors, they produce a number of costly or inefficient consequences. For instance, the current patent standard, with its emphasis on early sales and market share, will tend to accelerate $R \& D$ spending in the early stages of the innovation process-a potentially costly side-effect. ${ }^{235}$ All otlier things being equal, it probably

232. See supra note 156 and accompanying text.

233. Id.

234. See supra note 214 , especially the article by Ginn \& Rubinstein.

235. See supra note 182 and accoinpanying text. Note also that some courts in the past, perhaps implicitly recognizing these costs, refused to consider evidence of coinunercial success where the patentee was simply the first to enter a rapidly expanding market. See, e.g., In re Heldt, 433 F.2d 808, 812, 167 U.S.P.Q. (BNA) 676, 679 (C.C.P.A. 1970) ("general market increase" discredits coinınercial success); Unity Mfg. Co. v. Int'1 Spotlight Corp., 57 F.2d 945, 946, 12 U.S.P.Q. (BNA) 379, 380 (7th Cir. 1932) (treinendous growth in number of autoinobiles led to increased sales in autoınobile accessories); Dubilier Condenser and Radio Corp. v. Aerovox Wireless Corp., 37 F.2d 657, 660, 4 U.S.P.Q. (BNA) 273, 276 (2d Cir. 1930) (growth in radio industry led to coinunercial success of patentee's condensors). The Federal Circuit has kept this idea alive, at least in dicta. See 
is beneficial to give an incentive for firms to innovate as quickly as possible. ${ }^{236}$ A success-oriented standard of patentability, however, tends to reward nontechnological assets that contribute to a firm's innovational success, such as a superior distribution system, a uniquely effective organizational structure, or access to more capital. ${ }^{237} \mathrm{~A}$ patent system that rewards firms for cultivating such assets is likely to create excessive social costs because these assets have historically been developed without the added stimulus of the state-created patent monopoly. ${ }^{238}$ Moreover, a standard which grants patents based on current profitability, revenues, and market share-in other words, commercial success-may also reward monopoly power by insulating firms from technological competition. ${ }^{239}$

Leinoff v. Louis Milona \& Sons, 726 F.2d 734, 746, 220 U.S.P.Q. (BNA) 845, 854 (Fed. Cir. 1984) (Nies, J., dissenting); In re Sneed, 710 F.2d 1544, 1551, 218 U.S.P.Q. (BNA) 385, 390 (Fed. Cir. 1983) (rising sales could be result of increasing popularity of flexible plastic pipe generally, rather than particular inethod of installation).

236. This argument is implicit, for instance, in Kitch's "Prospect Theory." See Kitch, supra note 158 , at 284 . Kitch argues that novelty alone would be an economically sufficient criterion of patentability. See also Direct Protection of InNovation, supra note 12.

237. This appears to be at least part of the Hybritech story; see supra notes 222-24 and accompanying text. In this coimection, David Teece has recently described the importance of such "coinplementary assets" to innovating firms who are trying to appropriate the full value of their innovations. Teece, Profiting from Technological Innovation: Implications for Integration, Collaboration, Licensing and Public Policy, 15 RES. POL'Y 285 (1986). He argues that where imitation of an innovation is easy-because of weak intellectual property protection, or technology that is cheap to duphicate, or both-an innovating firm must gain control over such coinpleinentary assets as distribution, service, and related know-how to appropriate the full value of its innovation. Id. at 290-92.

238. This point is implicit in part of Edmund Kitch's original (1966) economic analysis of the nonobviousness standard. See Kitch, supra note 24, at 301:

[A] patent should not be granted for an innovation uuless the innovation would have been unlikely to lave been developed absent the prospect of a patent. Unlike the novelty test, [nonobviousness] does not view the inducement of investment in production and marketing facilities, after the innovation has been devcloped, as an appropriate function of the patent system. These are costs that must be borne by everyone who wishes to market the innovation and if, in the face of competition, investors do not find the innovation an attractive prospect, that is because there are better uses for their capital elsewhere, not because the coinpetitive situation should be altered.

239. For a case where the court saw this danger, see Digitronics Corp. v. New York Racing Ass'n, 553 F.2d 740, 193 U.S.P.Q. (BNA) 577 (2d Cir.), cert. denied, 434 U.S. 860 (1977). In this case a Second Circuit panel invalidated Digitronics' patent on a solid-state data processing system for parimutuel betting on horse races. The court found the imvention obvious in light of the rapid replacement of electronechanical components with solid state electronics. It refused to be swayed by Digitronics' evidence of commercial success, finding that there were no competitors in this niche market. See also Pentec, Inc. v. Graphic Controls Corp., 776 F.2d 309, 227 U.S.P.Q. (BNA) 766 (Fed. Cir. 1985); Hewes \& Potter, Inc. v. Myerson, 64 F.2d 336, 17 U.S.P.Q. (BNA) 418 (2d Cir. 1933); Wahl Clipper Corp. v. Andis Chipper Co., 66 F.2d 162, 18 U.S.P.Q. (BNA) 179 (7th Cir. 1933). For a Schunpeterian discussion of the effects of monopoly power on innovation, sec $R$. NELSON \& S. WINTER, supra note 2, at 388-89; F.M. SCHERER, supra note 2, at 175 . Sonte patent opiuions lave also commented on the various sources of monopoly power, including tradentarks. See, e.g., Eskimo Pie Corp. v. Levous, 35 F.2d 120, 122, 3 U.S.P.Q. (BNA) 23, 25 (3rd Cir. 1929). For an argument that patents can be used strategically in some situations to perpetuate monopolies, 


\section{B. The Other Secondary Considerations}

Although commercial success is by far the most important secondary consideration in proving nonobviousness, ${ }^{240}$ the other secondary considerations-licensing, long-felt need, failure of others, and copy$\mathrm{mg}^{241}$-also can be quite influential. Consequently it is worth examining these factors to understand their legal rationale and economic effects, and to evaluate their strength as evidence of patentability.

\section{Failure of Others: The Legacy of Learned Hand}

Unlike commercial success, the failure of others to make an invention proves directly that parallel research efforts were under way at a number of firms, and tliat one firm (the patentee) won the race to a common goal. As long as the race was long enough and there was a clear winner, it is difficult to find fault with such evidence as proof of patentability. ${ }^{242}$ In fact, since the failure of others is often one of the inferential steps underlying the commercial success doctrine, it makes sense for

see Gilbert \& Newberg, Preemptive Patenting and the Persistence of Monopoly, 72 AM. ECON. REV. 514 (1982).

240. Cf. Boyer, Commercial Success as Evidence of Patentability, 37 FordHAM L. REv. 573 (1969).

241. See supra notes 74-128 and accompanying text; 2 D. Cusum, supra note $19, \$ 5.05[5]$ (1987 \& Supp. 1987); Walker, Nexus Part II, supra note 74. A form of objective evidence that often assisted patent challengers in the past was proof of "near simultaneous invention." See id. \$ 5.05[7]. But the Federal Circuit held in two cases that this is no longer to be considered, by itself, as a proof of obviousness. See Hybritech, Inc. v. Monoclonal Antibodies, Inc., 802 F.2d 1367, 1380 n.4, 231 U.S.P.Q. (BNA) 81, 91 n.4 (Fed. Cir. 1986) (rejecting showing of simultaneous invention on grounds that others developed invention after patentee filed for patent and that other secondary considerations are "adequate" to establish patentability), cert. denied 107 St. Ct. 1606 (1987); Environmental Designs, Ltd. v. Union Oil Co., 713 F.2d 693, 698 n.7, 218 U.S.P.Q. (BNA) 865, 869 n.7 (Fed. Cir. 1983), cert. denied, 464 U.S. 1043 (1984). But see In re Merck, 800 F.2d 1091, 231 U.S.P.Q. (BNA) 375 (Fed. Cir. 1986) (affirming Patent Appeals Board holding that patented invention was obvious, and noting with approval Board's reliance on simultaneous invention as proof of high level of skill in the art).

The notion that near simultaneous invention is a poor indication of nonobviousness has been criticized-for good reason. See Walker, supra note 74, at 243. For the same reason failure of others provides effective proof of nonobviousness, see infra text accompanying notes 242-56, simultaneous imvention provides effeetive proof that a particular problem's solution was obvious to a number of skilled practitioners in the art. See Concrete Appliance Co. v. Gomeroy, 269 U.S. 177, 184-85 (1925); Fred Whitaker Co. v. E.T. Berwick Indus., 551 F.2d 622, 194 U.S.P.Q. (BNA) 113 (5th Cir. 1977); 2 D. Chisum, supra note $19, \S 5.05[7]$.

242. Many judges have sung the praises of failure of others. Justice William R. Day of the Supreme Court said: "It may be safely said that if those skilled in the mechanical arts are working in a given field and have failed after repeated efforts to discover a certain new and useful improvcment, that he who first makes the discovery ... is entitled to protection as an inventor." Expanded Metal Co. v. Bradford, 214 U.S. 366, 381 (1909); see also Krementz v. S. Cottle Co., 148 U.S. 556, 560 (1893) (noting that failure of defendant firm to solve button manufacturing problem was indicative of patentability). Recently, the Federal Circuit has shown a willingness to consider such evidence but has at times appeared to relax one of the two elcments essential to establish it-actual parallel research. See Fromson v. Advance Offset Plate, Inc., 755 F.2d 1549, 225 U.S.P.Q. (BNA) 26 (Fcd. Cir. 1985) (competitor did not develop the product because it did not see the economic advantage). 
courts to adopt a rule of thumb requiring the patentee to prove failure of others before commercial success will be given substantial weight.

For failure of others to be persuasive, a patentee must establish two preliminary facts. First, there must actually be parallel research aimed at the same goal. If two runners are on tracks of differing length or terrain, they will not be in a true race. Second, the patented imvention must be the result of more than minimal research efforts; quick results by one firm, followed in rapid succession by the same discovery at other firms, would tend to show that the problem being solved was trivial. The winner should not be judged on the basis of a sprint. ${ }^{243}$ Although it is dangerous to make rigid rules, failure over a period of several years indicates that the problem's solution was nonobvious. No specific term should be set, however, because intensively researched problems might justify a shorter period. ${ }^{244}$ As long as the patentee shows that the invention resulted from a significant research effort, and other firms pursued similar research, failure of others will be a rehable.secondary consideration in the determination of nonobviousness.

Perhaps no judge was more convinced that failure of others is a rehable consideration than Learned Hand. Judge Hand's considerable influence extends throughout patent law, but he was especially ardent-and characteristically eloquent-in championing the secondary factors, ${ }^{245}$ which he usually referred to under the rubric of "the history of the art."246 Although references to commercial success appear in some of Hand's opinions, ${ }^{247}$ he reserved his most sweeping support for evidence of long-felt need and failure of others. ${ }^{248}$

Judge Hand's regard for the failure of others-and his skepticism

243. See Clark v. Wright Aeronautical Corp., 162 F.2d 960, 966 (2d Cir. 1947); Ruben Condenser Co. v. Copeland Refrigeration Corp., 85 F.2d 537, 541 (2d Cir. 1936), cert. denied, 300 U.S. 665 (1937). See generally P. Blaustein, Learned HaNd on Patent Law 107, 113-16 (1983) (magnitude and intensity of efforts by others were crucial to Learned Hand's treatment of failure of others evidence).

244. See P. Blaustein, supra note 243 , at $105-11$ (collecting cases on this topic decided by Learned Hand); see infra note 248.

245. See Godula, Judge Learned Hand and the Concept of Invention, 9 IDEA 159, 160 (1965). See generally P. BLAUSTEIN, supra note 243.

246. See, e.g., Condenser Corp. of America v. Micamold Radio Corp., 145 F.2d 878, 879 (2d Cir. 1944), cert. denied, 324 U.S. 861 (1945); Crone v. John J. Gibson Co., 247 F. 503, 507 (2d Cir. 1917).

247. The only case where commercial success appears to have made the definitive difference to Judge Hand is Reiner v. I. Leon Co., 285 F.2d 501, 503 (2d Cir. 1960) ("We are of course acutely aware of the constant reminders in the books that the sale of a patented device is not alone a measure of its invention, and we accept that conclusion. Nevertheless, great commercial success, when properly scrutinized, may be a telling circumstance.") (emphasis added), cert. denied, 366 U.S. 929 (1961). Cf. infra notes $249-51$ and accompanying text.

248. See, e.g., Hookless Fastener Co. v. G.E. Prentice Mfg. Co., 68 F.2d 940, 941 (2d Cir. 1934) (long-felt need and repeated failures); Todd Protectograph Co. v. Safe-Guard Check Writer Co., 291 F. 613, 614 (S.D.N.Y. 1923) (failure of others); Auto Pneumatic Action Co. v. Kindler \& Collins, 
about commercial success-shows through clearly in his opinions. Even "[a]mazing success," he wrote, is not enough. "[T] hat is not the test of the validity of a claim." 249 The nore reliable test, as he described it in Ruben Condensor Co. v. Aerovox Corp. ${ }^{250}$ requires consideration of a series of preliminary factors before relying on commercial success:

While it is always the safest course to test a putative invention by what went before and what came after, it is easy to be misled. Nothing is less reliable than uncritically to accept its welcoine by the art, even though it displace[d] what went before. If the machine or composition appears shortly after soine obstacle to its creation, technical or economic, has been removed, we should scrutinize its success jealously .... We should ask how old was the need; for how long could known materials and processes have filled it; how long others had unsuccessfully tried for an answer. If these conditions are fulfilled, success is a reliable touchstone $\ldots . .251$

Besides the analytical rigor it lends to the nonobviousness inquiry, evidence of the failure of others has another virtue: it is relatively easy to obtain. Almost all firms keep detailed records of their research to establish critical dates for patent priority. ${ }^{252}$ Patentees often investigate the

247 F. 323, 327-28 (2d Cir. 1917) (long-felt need and failure of others); Victor Talking Machine Co. v. Carl Lindstrom Co., 279 F. 570, 571 (2d Cir. 1913) (long-felt need).

Moreover, Judge Hand meant long-felt need; in cases where the need was shown to have been recognized for one to five years, he found it unpersuasive. See, e.g., Safety Car Heating \& Lighting Co. v. General Electric Co., 155 F.2d 937, 939 (2d Cir. 1946); Nagy v. L. Mundet \& Son, Inc., 101 F.2d 82,82 (2d Cir. 1939) ("It is not safe to assume, because a single manufacturer for a few years has not discovered an improvement, that it was beyond the powers of rather commonplace talent .... The case is much stronger for an invention when it appears at the end of a period of active competition among several manufacturers ...."). One exception was the case of a patent relating to a shock absorber, in which Hand thought the intense concentration of inventive activity in the field of auto mechanics made a five-year need signifieant. See Hartford v. Moore, 181 F. 132, 137 (S.D.N.Y. 1910) ("thousands and tens of thousands of skilled meclanics have become faniliar with the whole mechanism" of the auto).

249. Merit Mfg. Co. v. Hero Mfg. Co., 185 F.2d 350, 350 (2d Cir. 1950).

250. 77 F.2d 266 (2d Cir.), cert. denied, 296 U.S. 623 (1935).

251. Id. at 268 (emphasis added).

252. Firms keep detailed records of the conduct of specific experiments, the construction of prototypes, and other research activities, see, e.g., Hybritech, Inc. v. Monoclonal Antibodies, Inc., 802 F.2d 1367, 1376 (Fed. Cir. 1986) (review of "corroborating Hybritech laboratory notebooks, internal documents, and pertinent testimony"), because the Patent Office requires documentary proof of the dates of two key steps in the invention process-conception and reduction to practice. See Patent and Trademark Office, U.S. Dep't of Commerce, Manual of Patent EXAMINING Procedures $\S 715.07$ (5th ed. 1983 and rev. 1987) ("FACTS, not conclusions, must be alleged [to establish invention], and they must be shown by evidence in the form of exhibits . . . [which may include] sketches ... reproductions of notebook entries ... [and] supporting statements by witnesses ...."); see also CTS Corp. v. Piher Int'l Corp., 593 F.2d 777, 780, 201 U.S.P.Q. (BNA) 649, 651 (7th Cir. 1979) (noting "the unexplained absence of the kind of evidence we would normally expect to see in a case of this kind, viz., [defendant's] records of the development, testing, and production of the device [defendant] alleged it had reduced to practice before the [date of plaintiff's invention]"); cf. R. Hill, Section 103 and Trial Before a Jury-Views of a District Judge, in WITHERSPOON, NONOBVIOUSNESS, supra note 19, at 6:101, 6:108 ("Many patent suits involve a 
research records of a defendant charged with patent infringement, because these records are highly relevant to questions of infringement, ordinary skill in the art, and parallel research activities. ${ }^{253}$ Moreover, a patentee trying to prove failure of others will often describe the research efforts of firms other than the infringer. ${ }^{254}$ Finally, during its review of the patents and competitive products in the prior art, a court will often compare the inferior solutions to the problem in the prior art with the patentee's solution. ${ }^{255}$ Summarizing the availability of failure of others

situation in which the creator of the patented device or some other important witness has made notes, memoranda or other writing regarding past events, acts or transactions, about which he proposes to testify.").

253. See, e.g., Hercules, Inc. v. Exxon Corp., 497 F. Supp. 661, 678-80, 207 U.S.P.Q. (BNA) 1088, 1103-05 (D. Del. 1980) (reviewing plaintiff's trial exhibits and trial testimony describing in detail each step in defendant's research); see also State Indus., Inc. v. More-Flo Indus, Inc., 639 F. Supp. 937, 943 (E.D. Tenn. 1986) (citing, in prior invention discussion, two letters and four engineering progress reports describing origin and conduct of defendant's research program). Alternatively, courts can base a finding of noninfringement or obviousness on a review of the research efforts of the accused infringer. See, e.g., Beloit Corp. v. J.M. Voith GmbH, 626 F. Supp. 991, 999, 228 U.S.P.Q. (BNA) 785, 789-90 (E.D. Va. 1986), aff'd, 802 F.2d 471 (Fed. Cir. 1987) (describing parallel research efforts of accused infringer; held, no infringement due to structural differences between patented and accused devices); Akzo, N.V. v. E.I. du Pont de Nemours, 810 F.2d 1148, 1149-50, 1 U.S.P.Q.2d (BNA) 1704, 1706 (Fed. Cir. 1987) (describimg accused infringer's research efforts, which were remarkably similar to the patentce's, and accused infringer's conclusion that the resulting invention would be found obvious if it persisted in pursuing its patent apphication; held, plaintiff's identical patented invention was obvious). Evidencc of parallel research also surfaces when patentees investigate whether an accused infringer directly copied the patentee's product. See, e.g., Water Technologies Corp. v. Calco Ltd., 658 F. Supp. 961, 970 (N.D. IIl. 1986) (defendant, accused infringer, "had been working in the field of water purification and water disinfecting," and "was not able to prepare or make [the patentee's invention] until after he secured the knowledge to do so directly froin [the patentee's liccnsee]."); Lam, Inc. v. Johns-Manville Corp., 206 U.S.P.Q. (BNA) 452, 456 (D. Colo. 1979) ("Reviewing [defendant's] efforts, it is certain that it worked long and hard to come out with a commercially acceptable [version of patentee's invention] ... . but, prior to the iustant revelation defendant's people had after the [patentee's invention] was sketched by defendant's representative, defendant and its engineers failed to figure out a workable [version of the invention]."), aff'd, 668 F.2d 462, 213 U.S.P.Q. (BNA) 1061 (10th Cir., 1982) cert. denied, 456 U.S. 1007 (1982).

254. See, e.g., Uniroyal, Inc. v. Rudkin-Wiley Corp., 837 F.2d 1044, 1049, 5 U.S.P.Q. 2d (BNA) 1434, 1437 (Fed. Cir. 1988) (discussing inconclusive study by the University of Maryland to show that patentee's invention worked where others had tried and failed); Sante Fe-Pomeroy, Inc. v. P \& Z Co., 569 F.2d 1084, 1097, 167 U.S.P.Q. (BNA) 449, 452 (9th Cir. 1978) (group working on problem solved by patentec researched for two years without arriving at solution); Reeves Instrument Corp. v. Beckman Instruments, Inc., 444 F.2d 263, 272, 170 U.S.P.Q. (BNA) 74, 81 (9th Cir. 1971) (fifteen approaclies to problem solved by patentee had been tried, and a graduate student at M.I.T. had studied the problem in detail but failed to solve it) cert. denied, 404 U.S. 951 (1971); Studiengesellschaft Kohle mbH v. Dart Indus., Inc., 549 F. Supp. 716, 734-35, 216 U.S.P.Q. (BNA) 381, 393-94 (D. Del. 1982) (extensive review of third party-competitor research efforts), aff'd, 726 F.2d 724, 220 U.S.P.Q. (BNA) 841 (Fed. Cir. 1984); Hercules, Inc. v. Exxon Corp., 497 F. Supp. 661, 680, 207 U.S.P.Q. (BNA) 1088, 1105 (D. Del. 1980) (reviewing attempts by four research groups, including defendant and plaintiff's licensor, to solve problem).

255. Dow Chemical Co. v. American Cyanamid Co., 229 U.S.P.Q. (BNA) 171 (E.D. La. 1985), aff'd, 2 U.S.P.Q.2d (BNA) 1350 (1987) (parallel research demonstrated by defendant's efforts to develop and/or license a catalyst for producing acrylomide; held, defendant infringed plaintiff's patent by licensing infringing catalyst from third party); see, e.g., Under Sea Indus. Inc. v. Dacor 
evidence, one ex-patent practitioner, Judge Conner of the Southern District of New York, observed:

So in every case I tried, I looked desperately for evidence of trial and failure; if I found it, which I usually did, I hammered away at that one theme, almost to the disregard of everything else. And it succeeded to an amazing degree. ${ }^{256}$

Of course, an invention will not always follow the failure of others. However, one must keep in mind that failure of others is not a requirement for patentability-only a superior indicator. Where a patentee is truly the first in a field, the technical merits of her invention can be expected to speak for themselves. While the courts must be careful to examine the competitive environinent of even a pioneering invention, a breakthrough development in a new field should demonstrate nonobviousness even without any secondary consideration evidence. Thus a preference for evidence concerning failure of otliers, while providing a good benchmark of nonobviousness for the normal invention, will not be an obstacle to patentability in the case of a significant advance into an uncharted technological field.

In sum, the failure of others provides an analytically rigorous foundation for determining nonobviousness. Failure of others is also a practical measure because the evidence needed to establish it is readily accessible. Consequently, as Judge Learned Hand pointed out, it is an excellent indicator of patentability in many cases, because it directly addresses the issue at the core of the patent standard: the technical merits of an invention.

\section{Licensing By Competitors}

Evidence that a number of licensees have paid the patentee to gain access to an invention appears to say everything commercial success does, and maybe more: Since licensees often compete with, or at least participate in, the same industry as the patentee-licensor, their decision to pay the licensor royalties constitutes a special form of tribute. ${ }^{257}$ Indeed, many decisions use "acquiescence" as a synonym for "licensing."258 As the leading commentator on patent law has remarked, "The

Corp., 2 U.S.P.Q.2d (BNA) 1706, 1709 (N.D. I1l. 1987), aff'd, 833 F.2d 1551, 4 U.S.P.Q.2d (BNA) 1772 (Fed. Cir. 1987) (reviewing products introduced by other companies attempting to solve problem eventually solved with patentee's invention); Plasser American Corp. v. Canron, Inc., 546 F. Supp. 589, 595-96, 217 U.S.P.Q. (BNA) 873, 828-29 (D.S.C. 1980) (describing defendant's earlier products that included features attempting, but largely failing, to address problem solved by patentee); Rohm and Haas Co. v. Owens-Corning Fiberglass Corp., 196 U.S.P.Q. (BNA) 726, 73233 (N.D. Ala. 1977) (describing dissatisfaction in art with fiberglass based on earlier research).

256. Conner, Winning Patent Infringement Suits-The Art of Swimming Against the Tide, in WITHERSPOON, NONOBVIOUSNESS, supra note $19, \S 4: 402$.

257. See 2 D. ChIsum, supra note 19, § 5.05[3], at 5-261 (1987).

258. Id.; see, e.g., Tracor, Inc., v. Hewlett-Packard Co., 519 F.2d 1288, 1304, 186 U.S.P.Q. 
theory behind use of commercial acquiescence is that persons would not normally act in a fashion contrary to their economic interests unless convinced of the patent's validity."259

The view that licensing is a superior indication of nonobviousness reflects several unarticulated premises; none of them are self-evident, and some are flatly wrong. They are as follows: First, that licensing is always undertaken to enhance the licensee's productivity rather than for ulterior purposes, such as to avoid litigation with the patentee, or to maintain a tacit level of cooperation in the industry; second, that hicensees are technological equals and direct competitors of the licensor; and third, that licensees inherently prefer to make their own inventions and choose to hicense another firm's technology only when it einbodies a significant and therefore patentable advance.

As to the first assumption, courts have long recognized that it is unwise to read too mucli into a firm's decision to settle a lawsuit by hicensing patented technology. In John E. Thropp's Sons, Co. v. Seiberling, ${ }^{260}$ decided in 1924, the Supreine Court held that licensing evidence is not conclusive evidence of a patentable invention when a firm elects to license the patented technology rather than defend an infrimgement suit. The Court suggested that licensing inay well be the best course of action open to an accused infrimger, given the expense and uncertainty of patent litigation. ${ }^{261}$ A nuinber of decisions after Thropp's Sons, mcluding some

(BNA) 468 (7th Cir. 1975) ("[a]s evidence of commercial acquiesence in ... the patent, [four firms] have taken licenses ... "); Phillips Elec. \& Pharmaceutical Indus. Corp. v. Thermal \& Elec Indus., Inc., 450 F.2d 1164, 1175, 171 U.S.P.Q. (BNA) 641, 649 (3d Cir. 1971) (using terms "licensing" and "acquiesence" interchangeably). See generally 2 D. CHIsum, supra note 19, §5.05(3) (section entitled "Commercial Acquiesence-Licensing").

259. Id. (footnote omitted).

260. 264 U.S. 320 (1924); see also Kleinman v、 Kobler, 230 F.2d 913, 914, 108 U.S.P.Q. (BNA) 301, 302 (2d Cir.), cert. denied, 352 U.S. 830, reh'g denied, 352 U.S. 919 (1956). But cf. Note, An Economic Analysis of Royalty Terms in Patent Licenses, 67 MinN. L. Rev. 1198, 1212-14 (1983). The author of this Note points out that as long as the royalty payable under the license is higher than the cost of a suit to invalidate the patent, licensees have an incentive to challenge patents they believe are invalid. Id. at 1214. While this is a valid observa ion, it ignores some of the subtlety of longterm interfirm relations, as described infra in the text accompanying notes 264-68. More importantly, though, even if the point is conceded, it does not undercut the argument that licensing per se should not conclusively prove the validity of a patent. There is always the possibility that the patentee-licensor will set the royalty rate low enough to make the license more attractive than a declaratory action to invalidate the patent. (The rate might even be higher than the average cost of such suits, because of risk aversion on the part of defendants/licensees; see infra notes 262-63). Such a scenario is not unlikely considering the time value of money, the relatively long time lag between product introduction and substantial sales (and hence royalty payment obligations) for many innovations, and the low royalty rate in many licensing agreements (frequently $2-10 \%$ of gross selling price). The upshot is that licensing agreements need to be carefully scrutinized to assure that they truly indicate "industry tribute."

261. Thropp's Sons, 264 U.S. at 329-30. There is uo question that patent litigation is expeusive. See Industrial Innovation and Patent and Copyright Law Amendments: Hearings before the Subcomm. on Courts, Civil Liberties and the Administration of Justice of the House Committee on the 
in the Federal Circuit, have followed this reasoning in discounting evidence of industry hicensing. ${ }^{262}$

Firms frequently agree to settleinents because of the uncertainty that accoinpanies a patent infringeinent suit. Litigation involves a wide range of possible outconies at several stages, including the initial decisions on patentability and infringement and determination of danuages. The rich economic literature tliat addresses such situations shows that people prefer to opt out when there is a wide range of possible outcoines, including soine that are very bad. Most, preferring to pay a fixed price to guarantee a inediocre but noncatastrophic outcoine, are "risk averse."263

Moreover, firms sometimes take licenses to preserve a delicate balance of relations within an industry or to assure future licensing by rivals. $^{264}$ Competing firms often cooperate in various ways to further

Judiciary, 96th Cong., 2d Sess. 166, 168, 172 (1980) (statement of D.R. Dunner, President, American Patent Law Association); id. at 592-93 (statement of S.A. Diamond, Commissioner of Patents and Trademarks); id. at 645-46 (statement of H.F. Manbeck, Jr., General Patent Counsel, General Electric Co.); id. at 697 (statement of R.B. Benson, Counsel, Allis-Chalmers Corp.). Every patent lawyer - and many business executives-knows of patent cases that have dragged on in Kafkaesque fashion for years and years. See, e.g., Western Elec. Co. v. Stewart-Warner Corp., 631 F.2d 333, 205 U.S.P.Q. (BNA) 183 (4th Cir. 1980), cert. denied, 450 U.S. 971 (1981); U.S. Indus., Inc. v. Norton Co., 210 U.S.P.Q. (BNA) 94 (N.D.N.Y. 1980); cf. Peckham, Should the U.S. Patent Laws Be Abolished?, 11 J. CONTEMP. L. 389 (1985) (citmg cost of patent litigation as one reason to consider abolishing patent laws).

262. See, eg., EWP Corp. v. Rehance Universal, Inc., 755 F.2d 898, 907-08, 225 U.S.P.Q. (BNA) 20, 26 (Fed. Cir. 1985), cert. denied, 106 S. Ct. 131 (1985); Schwinn Bicycle Co. v. Goodyear Tire \& Rubber Co., 444 F.2d 295, 168 U.S.P.Q. (BNA) 258 (9th Cir. 1970). Courts have been as skeptical of infringement suits settled with cross-licenses as of those settled with royalty-bearing licenses. See, e.g., Bally Mfg. Corp. v. D. Gottlieb \& Co., 222 U.S.P.Q. (BNA) 681 (N.D. Ill. 1984); Norris Indus. Inc. v. Tappan Co., 193 U.S.P.Q. (BNA) 521 (C.D. Cal. 1976), aff'd, 599 F.2d 908, 203 U.S.P.Q. (BNA) 160 (9th Cir. 1979). Some cases have pointed out that large firms with market power are especially likely to extract licenses from smaller firms in the same industry. See, e.g., Eltra Corp. v. Basic, Inc., 599 F.2d 745, 750, 756, 202 U.S.P.Q. (BNA) 630, 634, 640 (6tl Cir. 1979); 2 D. CHISUM, supra note 19, § 5.05[3], 5-262.2.

Rough empirical evidence demonstrates the validity of these concerns. In a study of semiconductor electronics innovations, Eric von Hippel reports that infringement suits (and threats of suits) are often settled with cross-licenses. He also notes an important fact about such settlements: "Who pays . . . is determined at least as much by the contenders' relative willingness to pay to avoid the expense and botlier of a court fight as it is by the merits of the particular case." Von Hippel, Appropriability of Innovation Benefit as a Predictor of the Source of Innovation, 11 RES. POL'Y 95, 102 n.9 (1982); $c f$. C. TAYlor \& Z. Silberston, The EConomic IMPACt of The Patent System $153,157,159$ (1973) (tables slowing that only half of the sampled license agreements in force in 1968 provided money income to licensees). Some economists have detailed the conditions under which licensing can be used to further the interests of a dominant firm. See Shapiro, Patent Licensing and R\&D Rivalry, 75 AM. ECON. REV. 25 (1985), and sources cited therein.

263. That is, even if tlie expected value (probability of event multiplied by gain or loss fiowing from that event) is the same for two sets of events, people will often opt out of events with higher variance. For a good elementary discussion, see W. Nicholson, MicroecoNOMIC THEORY 203-08 (3d ed. 1985). The decision on whether or not to litigate a patent is made more coinplex by the fact that many patent cases involve multiple patents. See Morgan \& Friedman, Probabilities of Losing as to At Least One Patent in Multi-Patent Litigation, 68 J. PAT. \& TRADEMARx OfF. Soc'Y 498 (1986).

264. Courts have not overlooked such motivations for licensing. See, e.g., EWP Corp. v. 
mutual interests. For example, some industries engage im a good deal of informal "know-how" trading. ${ }^{265}$ In other industries, rights to important technology are contributed to a pool from which all industry members may draw. ${ }^{266}$ And in almost all industries, patents serve an important function as "bargaining chips" in interfirm competition, negotiation, and exchange. ${ }^{267}$ Some economists have argued that extensive cross-hcensing in an industry can help overcome some of the disadvantages of firm-level R\&D, such as the inevitable disclosure of valuable results to rival firms and the transaction costs of one-shot licensing arrangements. ${ }^{268}$ Thus, given the variety of factors that motivate firms to license, courts should be wary of relying on hicensing as evidence of nonobviousness.

The second basic premise underlying the significance of licensing evidence is that the licensee and hicensor are technological equals and direct competitors. Courts assume that hicensors and licensees liave the same expertise because they assume that those firms coinpete for the market where the hicensed technology is relevant. Yet firms which license technology do not necessarily sell into the same markets as the licensee. At least one empirical study undercuts the assumption that direct competitors frequently engage in licensing. A survey of over 1800 licensing agreements by Caves, Crookell, and Killing revealed that firms

Reliance Universal, Inc., 755 F.2d 898, 907, 225 U.S.P.Q. (BNA) 20, 26 (Fed. Cir.) ("[Licensing] programs are not infallible guides to patentability. They sometimes succeed because they are mutually beneficial to the licensed group . . . "), cert. denied, $106 \mathrm{~S}$. Ct. 131 (1985).

265. In a fascinating recent paper, the economist Eric von Hippel has documented how interfirm exchange networks operate. He shows how process engineers call on engineers at other companies in the industry for information in solving technical problems. Von Hippel, Cooperation Between Rivals: Informal Know-How Trading, 16 REs. PoL'y 291 (1987).

266. The concept of a patent pool conjures up images of ommous international cartels, but in fact such arrangements are common-and perfectly legal-so long as they have a legitimate purpose and are administered fairly. See, e.g., Carpet Seaming Tape Licensing Corp. v. Best Seam, Inc., 616 F.2d 1133, 1141-42, 206 U.S.P.Q. (BNA) 213, 220-21 (9th Cir. 1980), on remand, 694 F.2d 570, 216 U.S.P.Q. (BNA) 873 (9th Cir. 1982), cert. denied, 464 U.S. 818 (1983).

The economic considerations behind pooled technology arrangements are evident from historical examples of such practices. See C. FREEMAN, supra note 2, at 35 (technology sharing in the petroleum industry). Even outside of patent pools, licensing can take on strategic dimiensions. See, e.g., Priest, Cartels and Patent License Arrangements, 20 J.L. \& EcoN. 309 (1977); see also Skil Corp. v. Lucerne Products, Inc., 489 F. Supp. 1129, 1144, 206 U.S.P.Q. 792, 806 (N.D. Ohio 1980) (cross-license was entered into to enhance both firms' chances of obtaining a patent), aff'd, 684 F.2d 346, 216 U.S.P.Q. (BNA) 371 (6th Cir.), cert. denied, 459 U.S. 991 (1982).

267. See Mansfield, Patents and Innovation: An Empirical Study, 32 MGMT. ScI. 173, 176 (1986) (although patents found not essential to developing innovations in many industries, firms still go to the bother of filing for them for "whatever delay is caused prospective imitators and ... [for use] as bargaining chips.").

268. See Katz, An Analysis of Cooperative Research and Development, 17 RAND J. EcoN. 527 (1986) (describing conditions under which royalty-free cross-licensing schemes can increase the efficiency of industry-wide R\&D); $c f$. Spence, Cost Reduction, Competition and Industry Performance, 52 ECONOMETRICA 101, 114-18 (1984) (arguing that in some industries, performance is better with high spillover). 
were much more likely to hicense peripheral technologies to new entrants or peripheral competitors (especially those based in foreign countries) than they were to hicense core technologies to direct competitors. ${ }^{269}$ The reason is obvious: Firms are reluctant to enable their direct competitors to compete because they fear an immediate threat to their competitive position would result. ${ }^{270}$

Licensing is not always an indication that a technological equal has evaluated a competitor's technology and found it superior. Instead, it may be more akin to the purchase of technology from an unrelated mdustry, in which case it is less of a horizontal transaction between equals and more of a vertical transaction between a supplier and a consumer of a specific technology. We do not normally speak of a firm as being in competition with another firm that only supplies it with an imput, nor do we necessarily presume that the suppher and consumer are technological equals. In the absence of direct evidence of actual competition, a decision to license should carry no tacit assumption that the licensed invention is somehow superior. Rather, licensing may merely reflect a firm's decision to purchase a required input from the licensor rather than from another firm or "from itself" (by making it in-house).

Finally, the third premise underlying rehance on licensing evidence is that the licensees are capable of duphicating trivial (hence unpatentable) inventions, and therefore will pay only for the rights to use significant advances. This assumption is wrong for two reasons. First, Caves, Crookell, and Killing discovered in their study that many firms take hicenses to diversify their product line or manufacturing processes. Their research suggests that licensees often are not in a position to determine whether they could duplicate the patentee's research. In fact, all that is required for hicensees to protect their interests is that they be technically competent to evaluate that research to decide whether they can use it. ${ }^{271}$

269. Caves, Crookell \& Killing, The Imperfect Market for Technology Licenses, 45 OXFORD BULL. ECON. \& STATS. 249, 260-62 (1983) [hereinafter Caves]. A group led by Edwin Mansfield of the University of Pennsylvania reached the same general conclusion after conducting a similar empirical study. See E. Mansfield, A. Romeo, M. Schwartz, D. Teece, S. Wagner \& P. Brach, Technology Transfer, Productivity and Economic Policy (1982) [hereinafter TECHNOLOGY TRANSFER]. These conclusions do not necessarily conflict with the point made above that patents facilitate interfirm cooperation and exchange. See supra notes 265-67 and accompanying text. They merely clarify what might be called the parameters of exchange: which firms exchange what kinds of technology. In fact, taken together with the strong evidence of interfirm cooperation presented above, they indieate that licensing (1) plays a number of different roles in industry, but (2) is limited to nonessential technologies. Both these conclusions are at odds with much judicial reasoning concerning licensing.

270. Caves, supra note 269 , at 262 ("Very seldom did any firm license core technology in its home market."). Theoretical work on licensing is in agreement. See Katz \& Shapiro, On the Licensing of Innovations, 16 RAND J. ECON. 504, 5 I0 (1985) (model shows that major innovations will not be licensed, but minor ones will).

271. See Caves, supra note 269 , at 256. Trade publications aimed at licensing professionals 
Caves, Crookell, and Killing also observed that licensees "utilize current and future technology agreements to develop and exten[d] a variety of inhouse skills."272

The second defect of this assunption is that even granting that a firm has the research capabilities to duplicate a licensor's invention, the firm may find it cheaper to hicense the invention regardless of whether it is patentable. At the right royalty rate an invention that is obvious in a patent law sense is still worth licensing for econoinic reasons. After all, firms commonly license trade secrets and know-how, which are valuable but unpatentable information. ${ }^{273}$ Thus the existence of a market transaction ought not be taken as a measure of the technical superiority of the licensed technology.

Fortunately, the Federal Circuit has shown some signs that it is aware of the problems with hicensing evidence. In soine cases, the court has required a patentee to introduce evidence of industry respect for the patented item in addition to evidence of hicensing before it found licensing persuasive. ${ }^{274}$ This additional evidence can take the form of especially favorable hicensing terms for the patentee or industry-wide praise for the invention. ${ }^{275}$

This refinement is the first step toward a inore reasonable use of licensing evidence. The research and analysis presented above, however, suggest that courts should go further. Specifically, when evaluating evidence of hcensing, courts should consider: (1) infrimgement suits or

supply a good deal of impressionistic evidence in support of this finding. See, e.g., Camp \& Wallander, Factors in Acquiring Technology, in 3 THE LAw AND Business OF LiCENSING 3C-27, $3 C-29$ to -30 (R. Goldscheider \& T. Arnold eds. 1986) ("Because training is so critieal a coinponent of technology transfer, many licensing agreements . . . specify that a certain number of experts must be brought into the firm to work with staff."); Goldscheider, The Art of Technology Auditing, in id. at $3 \mathrm{C}-83,3 \mathrm{C}-90$ (Where there is "a perceived corporate weakness," one would "determin[e] the relative cost of 'licensing in' some existing technology to fill the gap, as opposed to the delay, risk and cost of meeting the need by some in-house R\&D program.").

272. Caves, supra note 269, at 256; see also Camp \& Wallander, supra note 271, at 3C-33 (In order for licensees to be ablc to use licensed technology, hicensor must provide training assistance.).

273. See, e.g., 3 S. Ladas, Patents, TRademarks and Related Rights: National and INTERNATIONAL Protection \$ 876, at 1646-48 (1975) ("Transfer and Licensing of Know-liow"); Kitch, The Law and Economics of Rights in Valuable Information, 9 J. LEGAL STUD. 683 (1980).

274. E.g., Stratofiex, Inc. v. Aeroquip Corp., 713 F.2d 1530, 1539, 218 U.S.P.Q. (BNA) 871, 879 (Fed. Cir. 1983); see also Hercules, Inc. v. Exxon Corp., 497 F. Supp. 661, 680, 207 U.S.P.Q. (BNA) 1088, 1105 (D. Del. 1980).

275. In Hercules, the court rejected evidence of licensing, although the patent was ultimately declared valid. The opimion includes this instructive passage: "The Court concludes that the evidence regarding hicensing is not helpful because the parties did not present any evidence regarding normal licensing arrangements. Consequently, the Court is without sufficient knowledge to judge whether the licensing agreements ... favor Hercules or its hicensees." Id. But see Windsurfing Int'l, Inc. v. AMF, Inc., 782 F.2d 995, 1001-02, 228 U.S.P.Q. (BNA) 562, 566-67 (Fed. Cir.) (licensing evidence accepted despite fact that licenses were due in part to factors other than respect for clainied invention, such as inclusion of right to use patentee's trademarks), cert. denied, $106 \mathrm{~S}$. Ct. 3275 (1986). 
threats by the patentee prior to licensing; (2) the pattern of licensing in the industry; (3) the relative market position of the licensor and licensees; (4) the degree of direct competition between the licensor and licensees; (5) the technical expertise of the licensees in the field of technology covered by the licensor's patent; and finally, (6) specific terms of the licensing agreements relative to industry norms. Only when courts have considered and rejected all of these alternative motives should they give this evidence substantial weight in determining nonobviousness.

\section{Long-Felt Need}

In addition to commercial success, the failure of others, and licensing, courts sometimes rely on another secondary consideration, the existence of a long-felt need in an industry for a particular invention or solution. Despite this rehance, however, long-felt need by itself is often an unreliable indication tliat an invention was nonobvious. ${ }^{276}$ Like failure of otliers, evidence of long-felt need helps to identify an opportunity for profit whicl might liave motivated firms to enter a race to create a patentable invention. Unlike failure of others, however, long-felt need does not prove that the race actually occurred or that the patentee won it. ${ }^{277}$ Similar to commercial success, evidence of long-felt need requires a series of inferential steps in order to conclude that there has been patentable invention. ${ }^{278}$

\section{Copying}

Evidence that competitors copied a patented product is similarly a poor indicator of nonobviousness. At first blush, such evidence might appear to support the patentability of the product. If it were not a significant technical advance, why would anyone want to copy it? Indeed, this reasoning has been adopted in a number of decisions of the Federal Circuit. "[C]opying a patented invention," the court has stated more than

276. See, e.g., Fromson v. Advance Offset Plate, Inc., 755 F.2d 1549, 225 U.S.P.Q. (BNA) 26 (Fed. Cir. 1985) (knowledge of need for and potential profit from device such as patentee's contributes to finding of nonobviousness); see also 2 D. CHISUM, supra note 19, $\$$ 5.05[1] (collecting cases on long-felt need and failure of others).

277. See, e.g., Fromson, 755 F.2d 1549, 225 U.S.P.Q. 26 (for seven years prior to invention, firms knew about the economic benefits that would accrue to the one who made the invention first; parallel research efforts can thus be presumed, even though such efforts were not established at trial). The court in effect collapsed long-felt need into a showing that firms knew about the potential benefits of an invention.

278. One theoretical model of invention and innovation could be said generally to support the inferences linking long-felt need with a nonobvious invention. F.M. Scherer's model of innovation includes the assumption that competing firms will try the most obvious (that is, the most promising) experiments first; thus, the fact that many firms havc been researching the same problem for a substantial period of time would tend to support the inference that the inventor who solved the longfelt need relatively late in the research game had tried a low-probability and consequently nonobvious experiment. See F.M. ScHERER, supra note 2, at 67, 74 (1984). 
once, "rather than one within the public domain, is mdicative of nonobviousness."279 The problems with this reasoning become evident, however, after sone reflection. Undoubtedly, copying indicates that the patentee has discovered something of value to competitors. However, because even an obvious improvement may be worth copying, copying alone does not necessarily signify patentability. ${ }^{280}$

Moreover, the use of copying as proof of patentability inay discourage firms from imitating their competitors' incremental product changes when those changes arguably fall within the scope of a patent. Since the ultiniate beneficiaries of feature-by-feature competition and imitation are consumers, a reduction in imitation might harm consuiners most of all.

The patent system, in fact, strives at almost every turn to protect routine imitation. The Supreme Court, for instance, in Lear Inc. v. Adkins, ${ }^{281}$ struck down the right of a patentee to prohibit its licensees froin challenging the validity of a licensed patent. The underlying policy was clear; the Court wanted to encourage hicensees to challenge the validity of patents, and thereby act as vigilant guardians of high patent standards. ${ }^{282}$ Minor advances are to remain freely available to competitors.

Despite the general benefits of a firm policy in favor of imitation, reliance on copying may be acceptable when it supplements a showing that others have tried and failed to achieve the result claimed by the patentee. In this context, evidence of copying constitutes an additional showing of failure. Again, however, as pointed out in our earher discussion of failure of others evidence, we should insist on a preliminary showing of parallel research. Without this, there is no proof that the infringer copied the invention in frustration after she failed to solve the problem.

279. Windsurfing Int'l, Inc. v. AMF, Inc., 782 F.2d 995, 1000, 228 U.S.P.Q. (BNA) 562, 563 (Fed. Cir. 1986), cert. denied 106 S. Ct. 3275 (1986); see also Panduit Corp. v. Dennison Mfg. Co., 774 F.2d 1082, 1099-1100, 227 U.S.P.Q. (BNA) 337, 348-49 (Fed. Cir. 1985), vacated 475 U.S. 804 (1986), cert denied 107 S. Ct. 2187 (1987).

280. See Cable Elec. Prods., Inc. v. Genmark, Inc., 770 F.2d 1015, 1028, 226 U.S.P.Q. (BNA) 881,889 (Fed. Cir. 1984) ("It is our conclusion that more than the mere fact of copying by an accused infringer is needed to make that action significant to a determination of the obviousness issue"); Vandenberg v. Dairy Equip. Co., 740 F.2d 1560, 1567, 224 U.S.P.Q. 195, 197 (Fed. Cir. 1984) (copying of dimensions from patentee's product is not an objective indicium of nonobviousness).

281. 395 U.S. 653 (1969). For a critique of Lear, on the basis that it prohibits small firm licensors from shifting the risk of patent hitigation to larger hicensees and thus introduces greater uncertainty into the R\&D process, see Dreyfuss, Dethroning Lear: Licensee Estoppel and the Incentive to Innovate, 72 VA. L. REV. 677 (1986).

282. Lear, 395 at 673-74. 
$\mathrm{V}$

\section{What Should Be Done About the Secondary CONSIDERATIONS?}

This section summarizes the arguments and analysis presented in the previous sections, and suggests how the courts ought to change their treatment of the secondary considerations in determiming patentability.

\section{A. Commercial Success}

Reliance on commercial success as an indication of patentability is likely to produce two undesirable consequences. First, by losing sight of a patented invention's technical merits and the process by which it was developed, courts may make erroneous assumptions about the meaning of commercial success. Although the number of errors may vary according to the forces that affect a successful innovation, generally, a court will be more likely to draw incorrect conclusions than under a test that did not consider commercial success.

Second, courts risk rewarding efforts that the patent system is not designed to reward. The economic models of innovation explain that courts that use commercial success indiscriminately will overlook the importance of the revenue aspects of the innovation decision. As a result, courts will tend to reach incorrect results when measuring an invention for patentability. At its worst, rehance on commercial success rewards firms with a patent when they have successfully mastered aspects of innovation that are important in themselves, such as superior distribution or marketing skill, but are unrelated to the goal of the patent system: fostering technological invention.

The remedy is to link commercial success witl failure of others. ${ }^{283}$ Using both factors bypasses the spurious inferential bridge between success and significant invention, thereby ensuring that patents reward pure invention and not market strategies. Moreover, the failure of others can often be establislied on the basis of readily available evidence, such as competitors' detailed records and the testimony of researchers in the industry.

As an alternative reinedy for overreliance on coininercial success, courts should tighten the requirements for accepting an innovation's success as proof of nonobviousness. Each element of the innovation process should be considered-those fostering success, and those inhibiting it. Courts should encourage patent challengers to introduce evidence on the

283. This approach is consistent with the reasoning of several older cases. See, e.g., Kaakinen v. Peelers Co., 301 F.2d 170, 173 (9th Cir.) (commercial success strong evidence of patentability when many trained artisans have been working on improvements similar to patentee's for many years), cert. denied, 371 U.S. 823 (1962); Georgia Pac. Corp. v. United States Plywood Corp., 258 F.2d 124, 133 (2d Cir.), cert. denied, 358 U.S. 884 (1958). 
full spectrum of demand-side factors contributing to success. As described in our earlier discussion of the economic literature on innovation, these factors may include: (1) existing product limes, whose profitability may deter entry into new product development races; (2) different research priorities and procedures based on experience in the market or firm-specific preferences (such as traditional emphasis on imitative research); (3) the patentee's superior market sensitivity, manifested for example in greater emphasis on user education, publicity, market forecasting, distribution, and service; and (4) the patentee's advertising and promotional activities.

\section{B. Other Secondary Factors}

As explained above, courts must begin to emphasize the importance of evidence concerning the failure of others in determining patentability, particularly when the patentee presents evidence of commercial success. No other secondary factor is as direct in its proof that the patentee has made a significant technical advance. No other factor is less subject to ambiguity. Finally, no other factor is as effective at placing the imvention in the context of actual R\&D competition.

With respect to the use of licensing evidence, a trial court should exainine a checklist of circumstances surrounding the licensing agreements, representing the reasons otler than technical superiority why a licensee might choose to license the particular patent in question: these include threats of suit, interfirm technology-sharing arrangements, and the terms of the licensing agreements. Only when these reasons are elimmated sliould a court be permitted to attribute licensing to the technical superiority of the invention and hence rely on it in deciding the issue of nonobviousness.

Long-felt need, we have seen, is a problematic factor. It suggests failed attempts by others but does not dehiver proof of failure. It is therefore less helpful than direct proof of failure. Owing to the many factors that can lead firms to miss a inarket opportumity, or to intentionally ignore one, long-felt need should not be relied on to establisl patentability.

The same is generally true of copying evidence. The patent system's emphasis on the free availability of nonpatented information suggests caution in the use of copying evidence. When used as the final step in proving failure of others, evidence of copying may have value, but only when it demonstrates abandoument of a failed attempt to invent the patented device or process.

A final word remains to be said about the effects of the doctrinal modifications suggested in this Article. Admirers of the Federal Circuit's efforts to brimg stability to patent law have every reason to support 
these proposed changes. As described in Section II, the court's decisions concerning the nexus requirement are confusing and difficult to reconcile; thus, they give the lower courts little guidance concerning the required relationship between secondary considerations and technical features of the patented invention. The changes proposed above are designed to ground the secondary considerations in the technical merits of an invention. The commercial success of an innovation may be attributable to many causes, but a showing of the failure of others makes it more likely that the right factor-techmical superiority-is being rewarded. A requirement that courts systematically eliminate marketside factors in assessing the causes of success would serve much the same purpose.

\section{CONCLUSION}

I have argued in this paper that the Federal Circuit has used one of the secondary considerations outlined in the Graham opinion, commercial success, to partially transform patentability doctrine into an instrument that rewards innovation rather than invention. I have also pointed out problems in the court's use of the other secondary considerationslicensing, the failure of others, long-felt need, and copying. The Federal Circuit's use of all the secondary considerations reflects an implicit model of the innovation process that tends to underestimate the significance of market-side factors. Economic theory and empirical research demonstrate the shortcommgs of such an approach; it is not only analytically flawed but also potentially inefficient and costly.

I have argued that an overemphasis on successful innovation, coupled with reduced attention to the presence or absence of a true invention, reinforces only one of the dual policy goals of the patent system: providing incentives to imventors. It ignores the goal of encouraging mventors to disclose teclinical infornation. Only when an inventor discloses something significant-something that is not obvious to the other practitioners of the art-is a patent warranted. When, on the other hand, a patent for an insignificant technical advance is mistakenly granted or upheld, society may suffer substantial costs because a techmique that belonged to the public is made into private property.

Lest we grant and upliold too many patents on the basis of ill-considered evidence, we must temper our use of the secondary factors. The stakes are too significant, and the methods for remedying our present defects too close at hand, to permit the patent system to reward innovation at the expense of fostering disclosure. In order for the patent system to contimue lielping us address the economic challenges we face, it must continue to reward true invention, by looking beyond successful innovation for the presence of a significant teclinical advance. 